๘。 


THE BIRD FOOT RACE IN

FOLLIES 


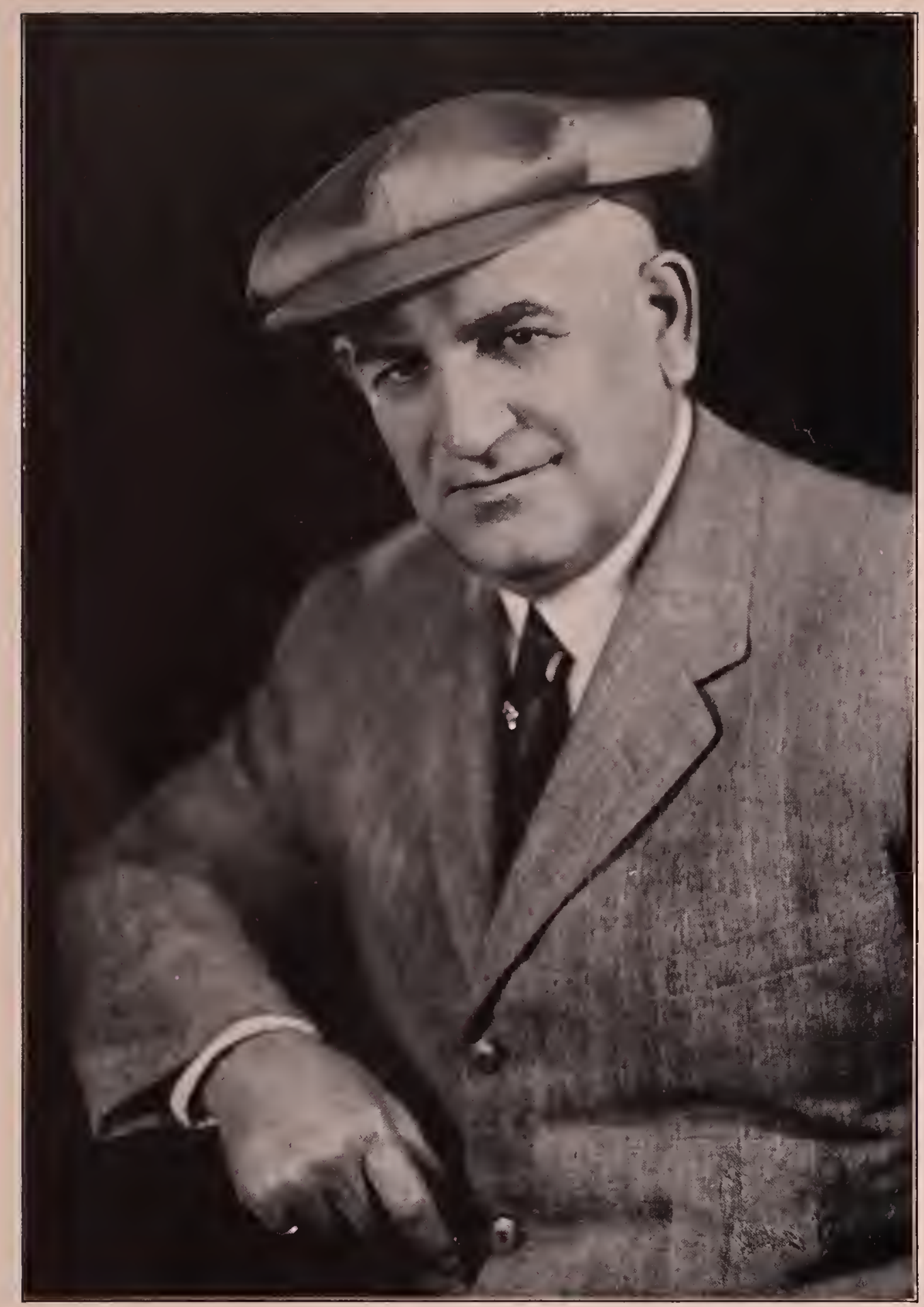

THE AUTHOR 


\title{
THE \\ BIRD FOOT RACE \\ IN \\ FOLLIES
}

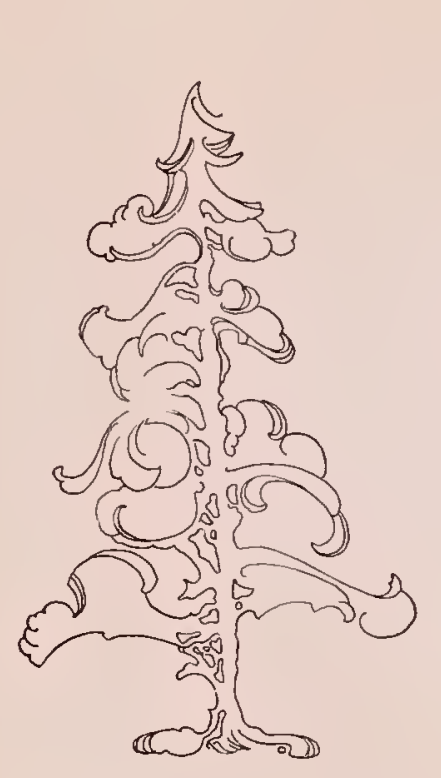

\author{
By \\ Robert E. Samis
}
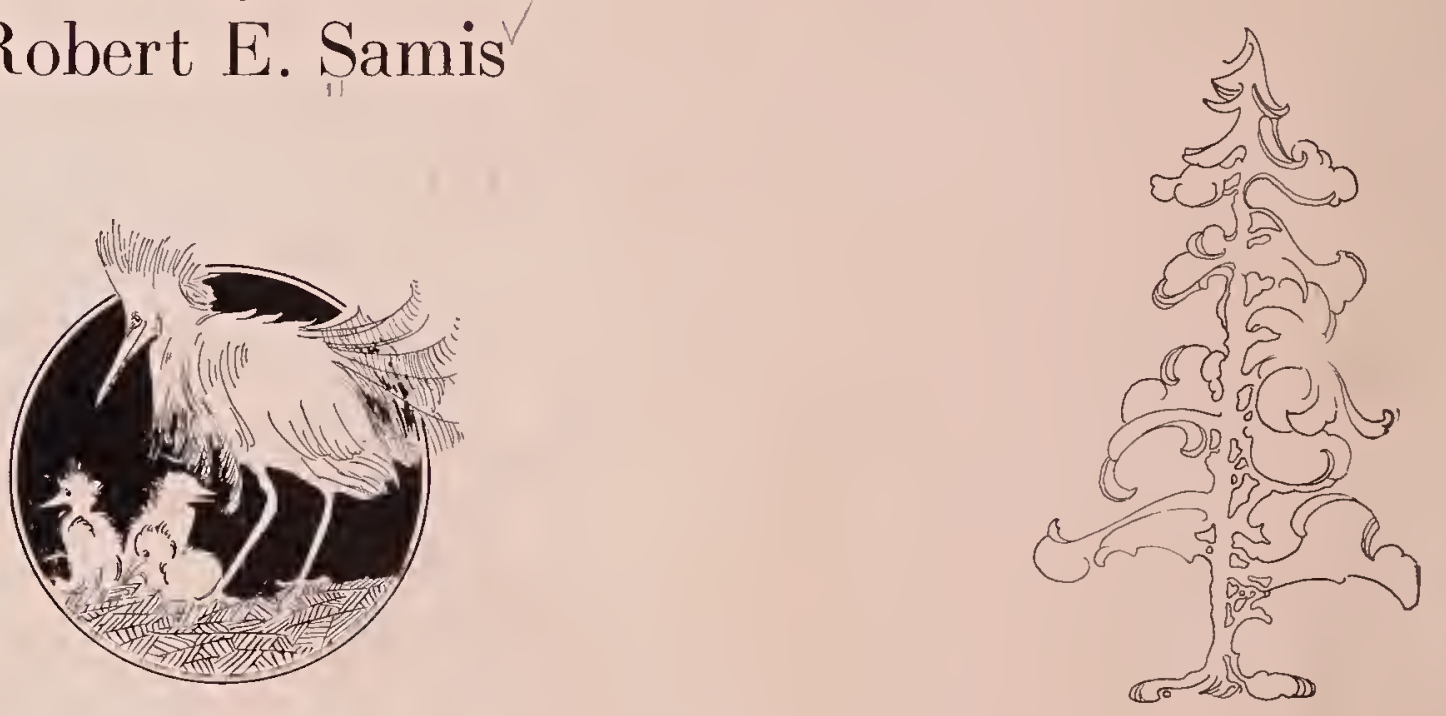

$\vdots \vdots$

SAMIS PUBLISHING COMPANY Publishers

Kansas City Missouri 


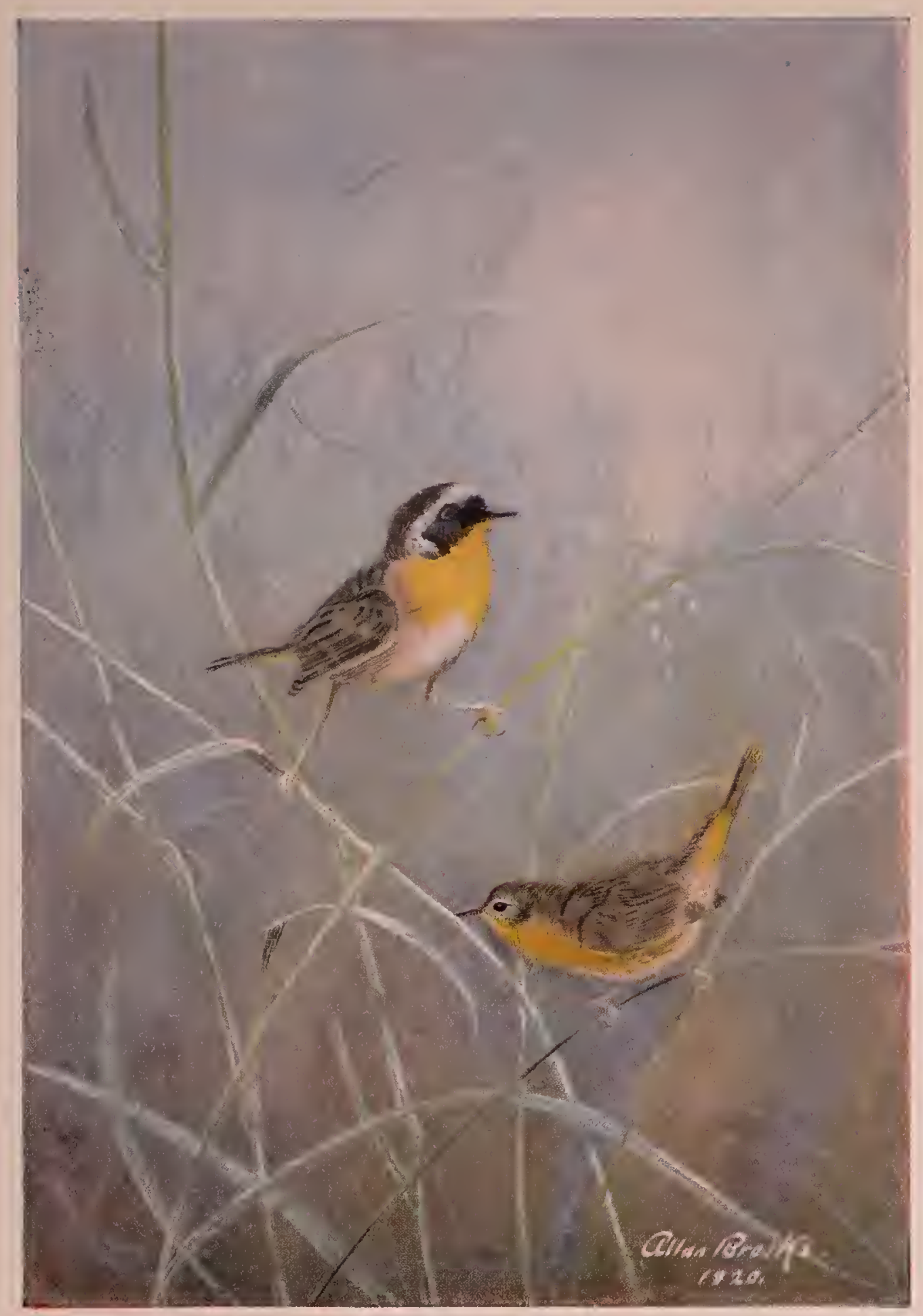

MARYLAND YELLOW-THROAT

THESE COLOR PLATES OF BIRDS, SEVENTY-TWO IN ALL, HAVE BEEN ARRANGED FOR THROUGH THE COURTESY OF T. GILBERT PEARSON AND THE NATIONAL ASSOCIATION OF AUDUBON SOCIETIES, NEW YORK CITY.<smiles>C1CCC2(CC1)CCCC2</smiles>

COPYRIGHT, I923, I924, BY

ROBERT E. SAMIS

ALI RIGHTS RESERVED, INCLUDING THAT OF TRANSLATION INTO FOREIGN LANGUAGES, INCLUDING THE SCANDINAVIAN

(C) $014808888^{\circ}$<smiles>[CH]C</smiles> 
DEDICATED TO

MARGUERITE SAMIS

BOBBY HOSMER

JANICE HOSMER

ARTHUR V. SAMIS, Jr.

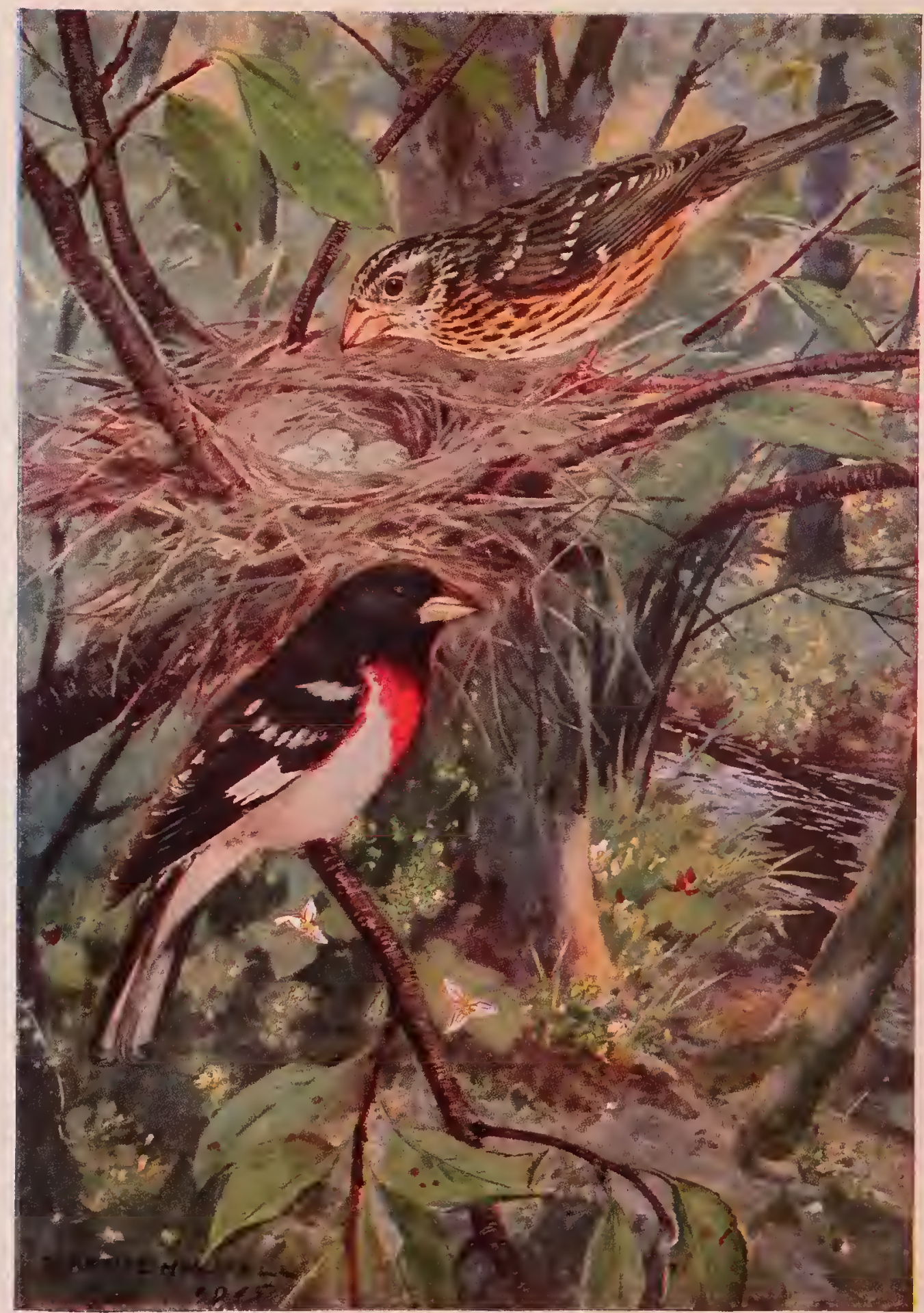

ROSE-BREASTED GROSBEAK 

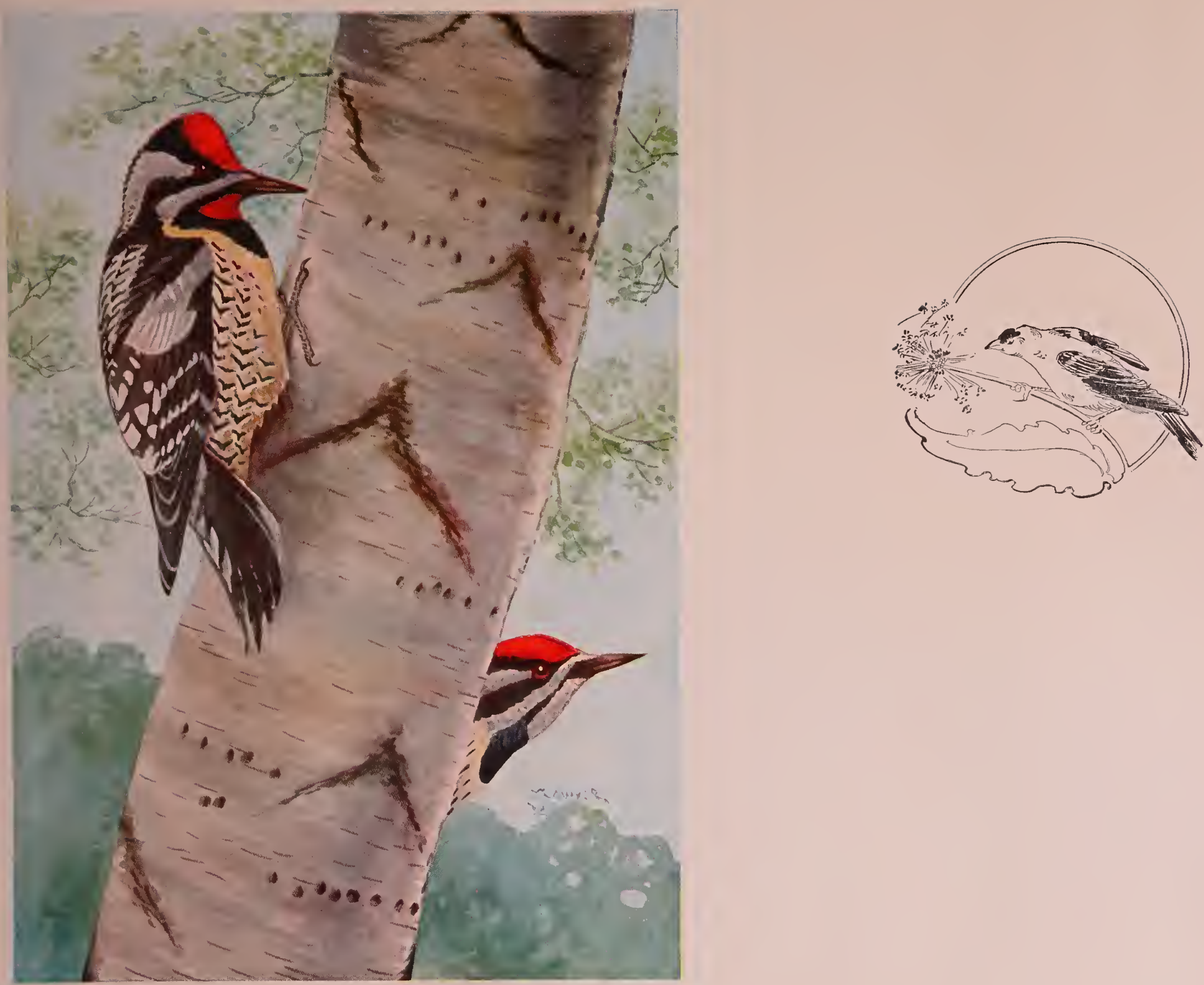

YELLOW-BELLIED SAPSUCKER

\section{INTRODUCTION}

This book has been written for the amusement and entertainment of children. It is full of educational features and also gives a short comic digest in which a large number of North American birds are represented as taking part in the race. (Web-footers are not included.) Many of the illustrations show the birds in their natural colors, combined with the Follies of the birds' foot race. The use of the race-track with race-track terms will be enjoyed by the grown-ups as well as the young. 

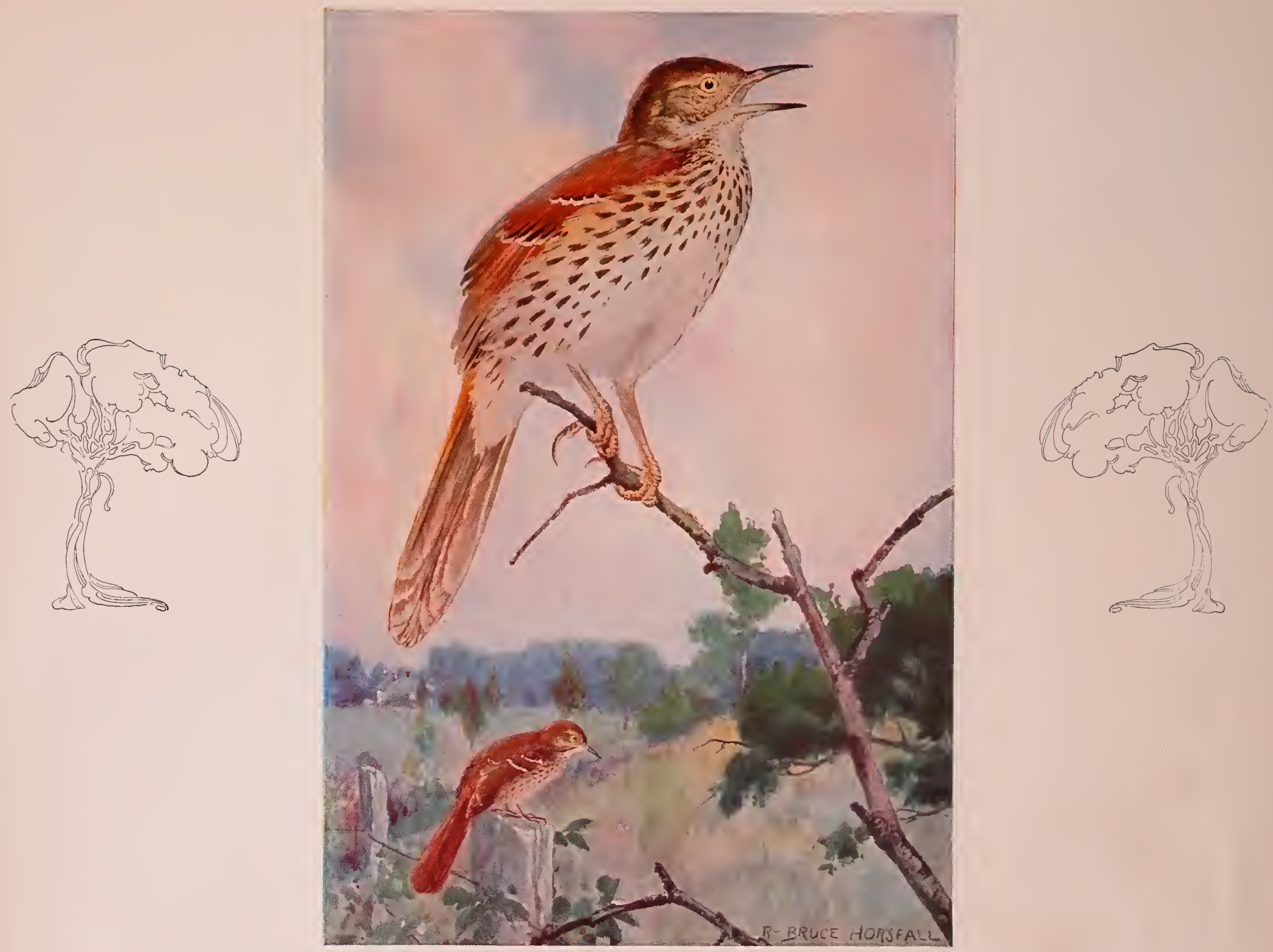

\section{MR. BROWN THRASHER}

"I've been working for years Other birds for to teach, At last they have asked me, To make a bird speech.

"The world has moved for ages, And no one has ever heard The first consideration of Amusement for a bird.

"Many things have been talked of, But none have taken place, So now let's all decide and Give a bird foot race.

"Being such an undertaking, And to save enormous loss, I believe it would be wise, To make the Eagle boss.
"He has such a wide acquaintance Over the entire land,

He would make all arrangements, Even to the selecting of a band.

"We must make it interesting By offering a good prize, As when birds are on foot, They are at a risk of their lives.

"A big bed of fat worms

Would be most tempting, they say, So if that suits the Eagle

We will let it go that way.

"For a good entertainment

We will not be without,

We'll leave it to the Eagle

To bring it all about." 


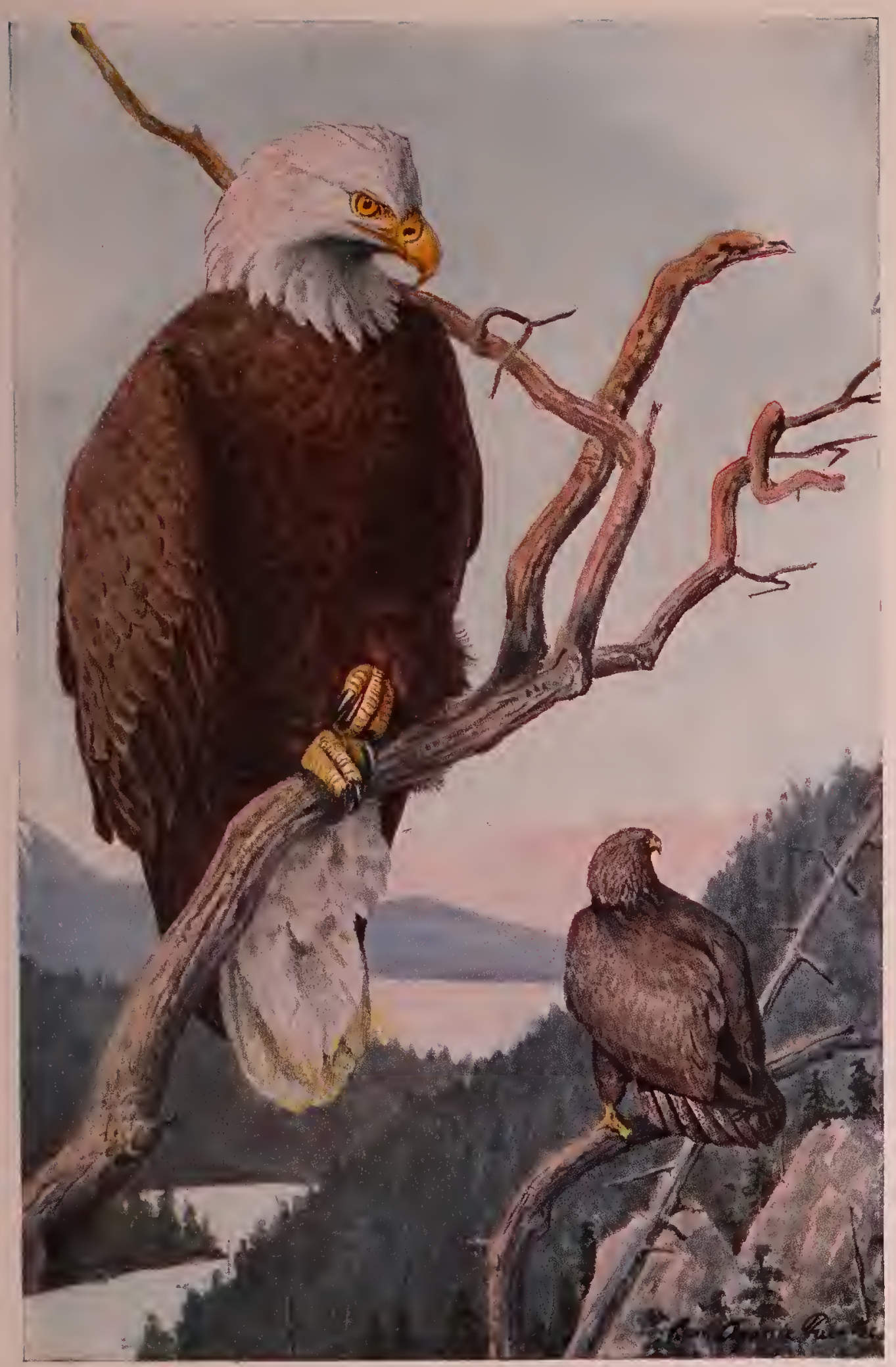

THE EAGLE

"I'm the Nation's old stand-by, From the East to the West, A companion to Old Glory, The Flag that is best.

"On gold and silver money I've been chosen for space, I am proud of my makeup That I can hold such a place.

"I just learned of the foot race They are arranging for birds, It sounds the most reasonable Thing that I've heard.

"Birds have led no amusement Since the landing of Noah's Ark, And think this a grand opening To give them a good start.

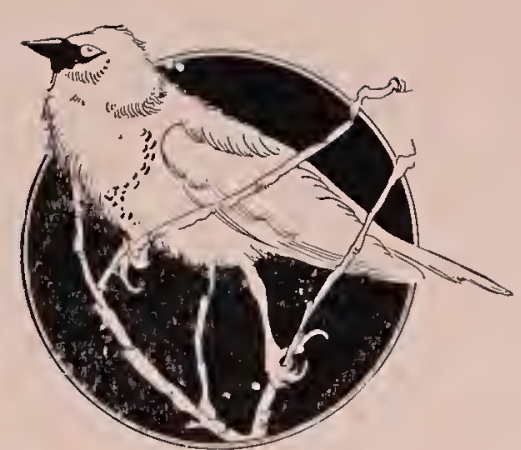

"For the whole information I am quite at a loss, I've just learned this morning That I'm to be boss.

"I'll call all the birds And then we will see After due consultation Who my officers will be.

"There's the Plover, the Magpie, The gay black-wing Chickadee, The Crow and the Raven Would be good birds to help me

"There are many more workers That would be alright But for a police bird, I want one that can fight.

"Towin the bird foot race 'Twould be a big gain. I will give the judge-ship To the old Sand-Hill Crane.

“The Parrot's make-up And motions are slow, The place for that bird Is a job to say 'Go!'

"We need a good gate bird, And one who won't shirk, I wonder if we could get The old Ostrich to work.

"Then the big Pelican He works with great will, He could carry the proceeds Back home in his bill." 


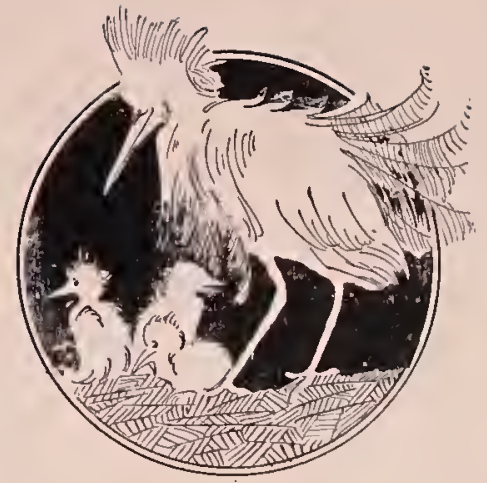

THE RACE-TRACK BAND

The Purple Finch and Crossbill

Will be in the grand stand

To help in the music and

Lead them in the band.

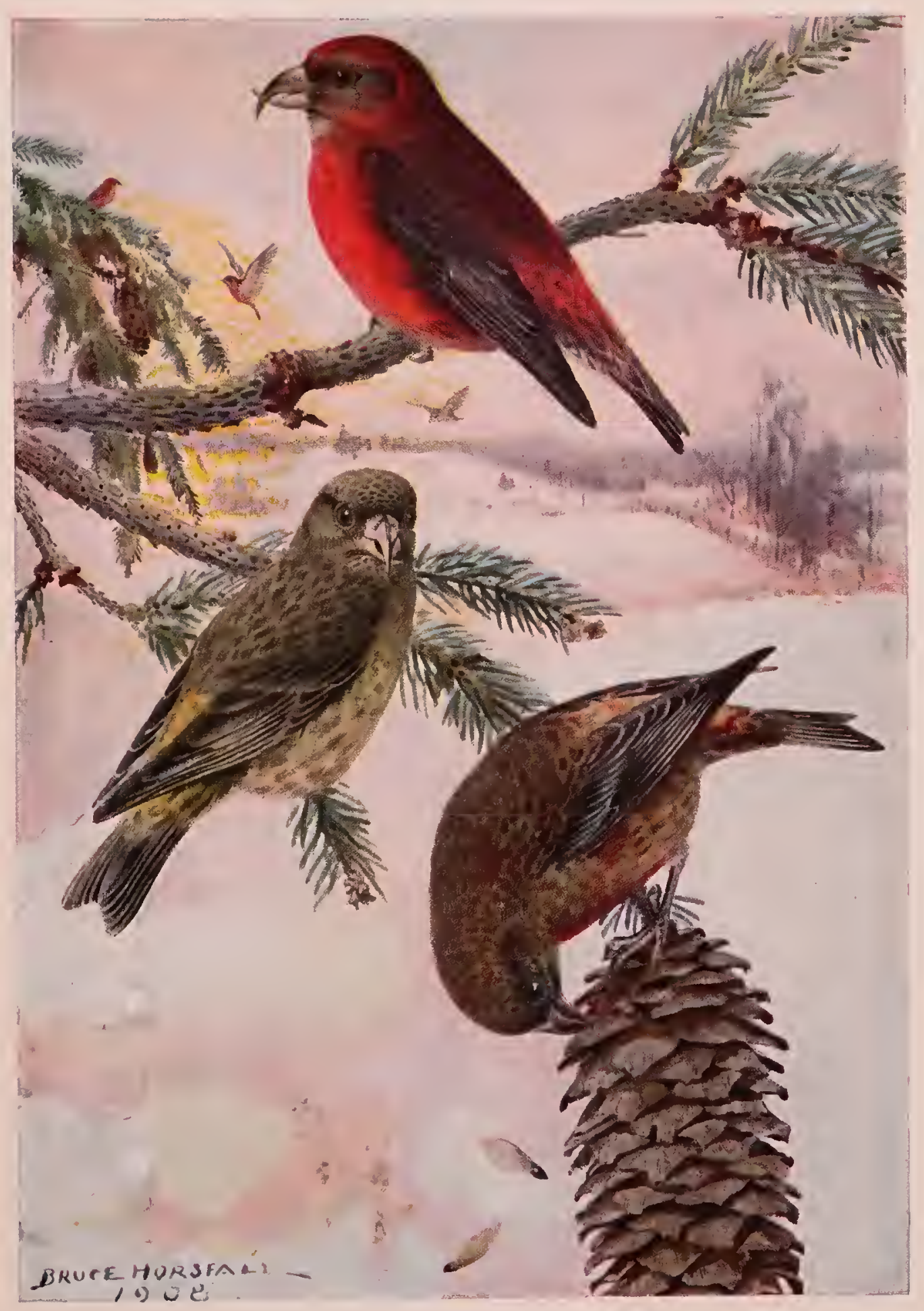

RED CROSSBILL

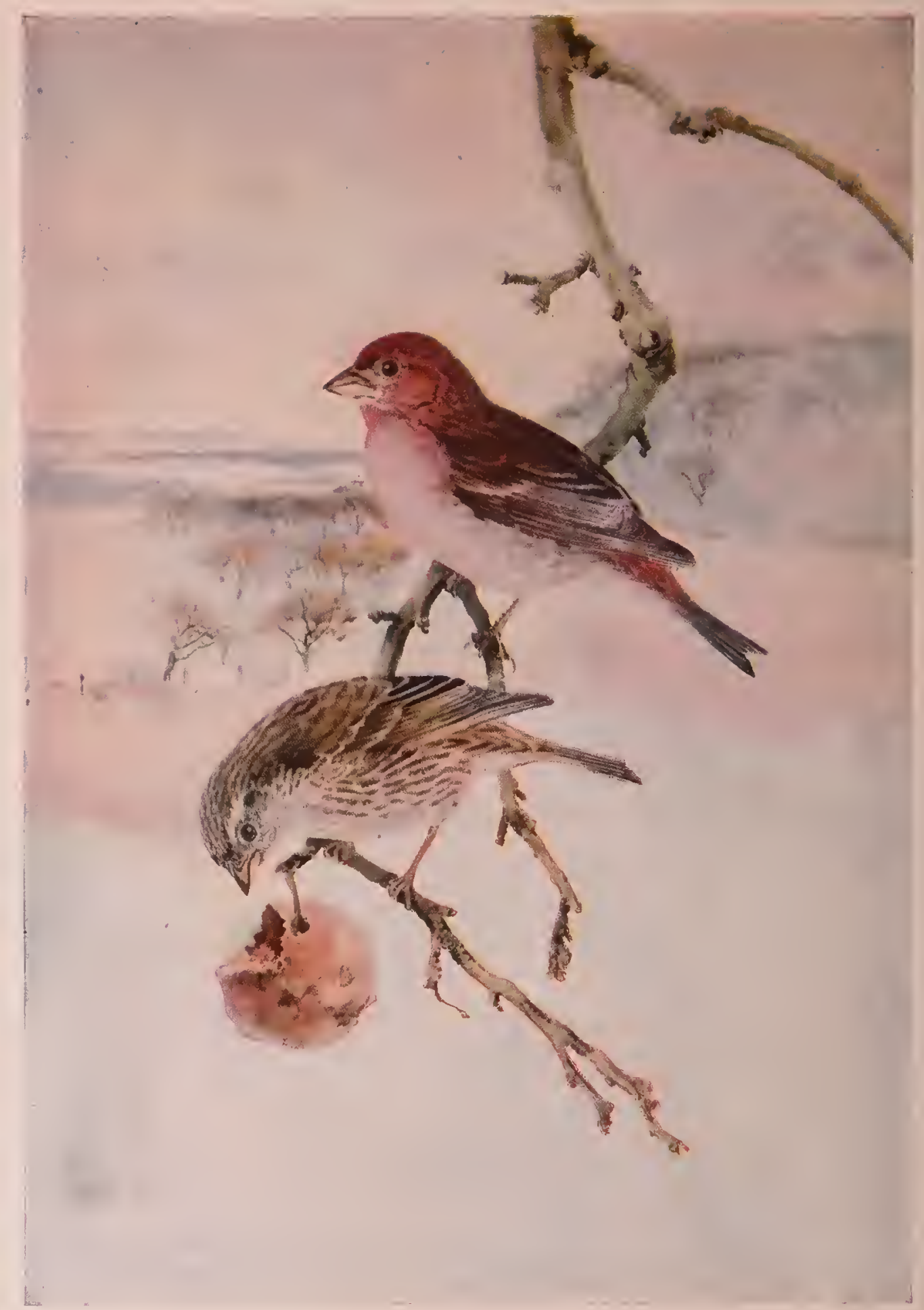

PURPLE FINCH

The Wren also will help them

As he's a "tee-wee,"

And for their assistant

We will have the Towhee.

We should have some good music,

We are judging, you see

From the music they give us

In the tops of the tree.

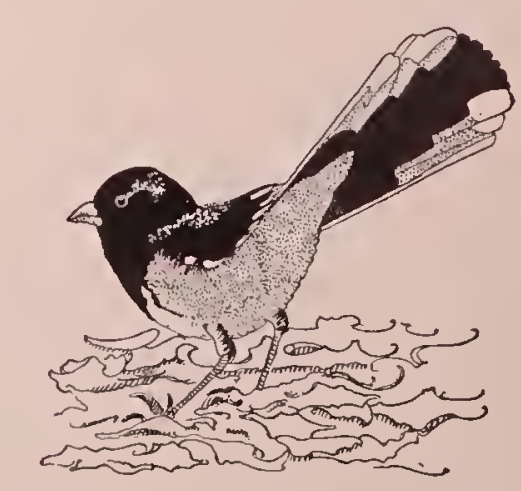




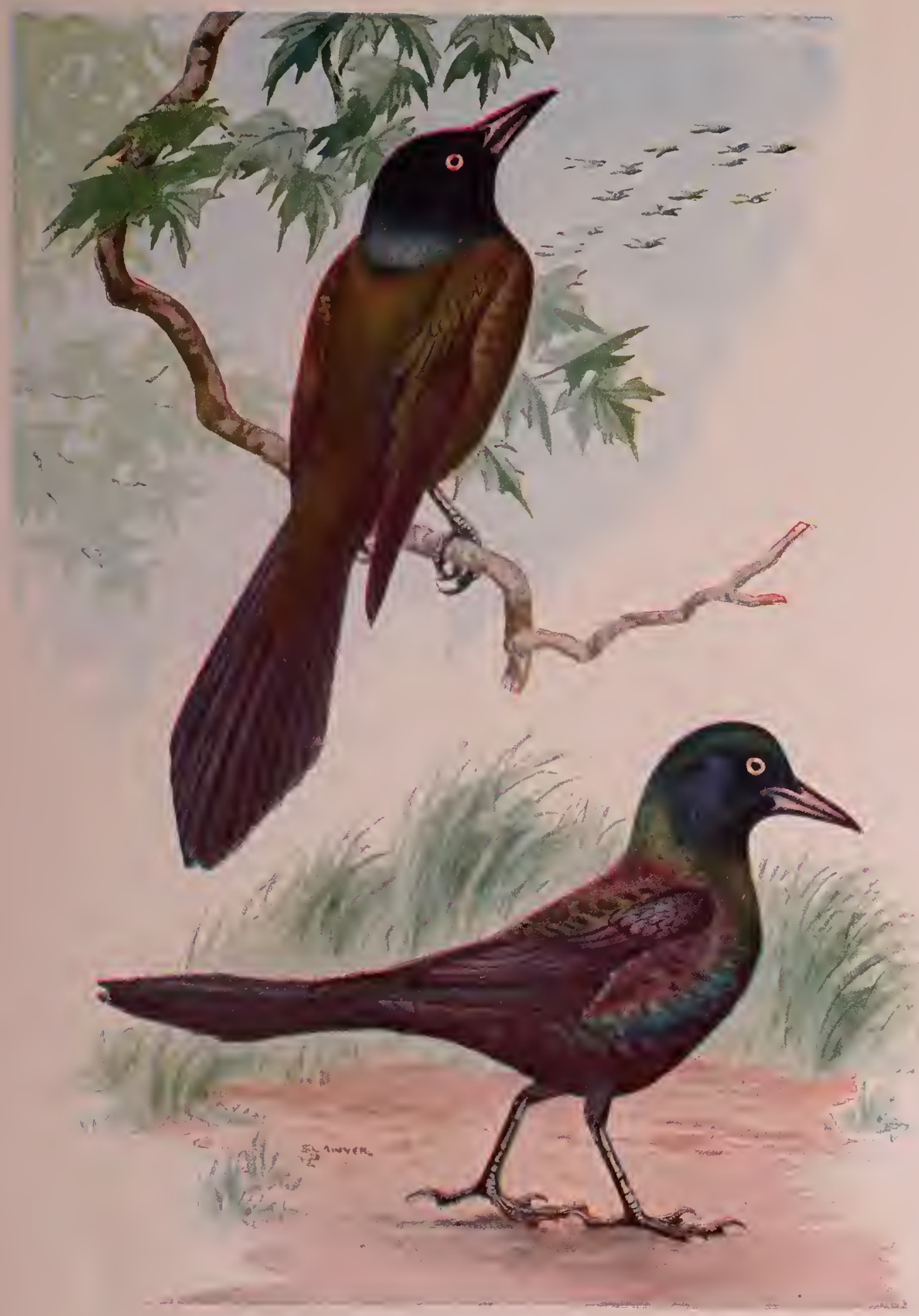

PURPLE GRACKLES

The Eagle says, on referring back,

Birds should be appointed to watch the track That would be a job, all the officers think, For the Purple Grackles and the Bobolink.

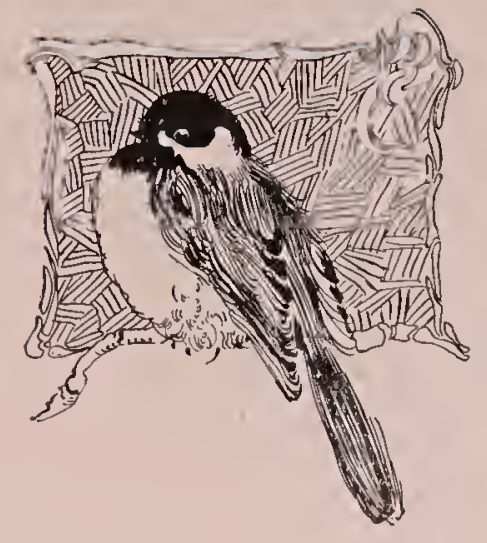

They could sell refreshments there as well, Also have charge of the big bird hotel. Birds that come a long way, for this race meet Will need a bird hotel, where they all can eat.

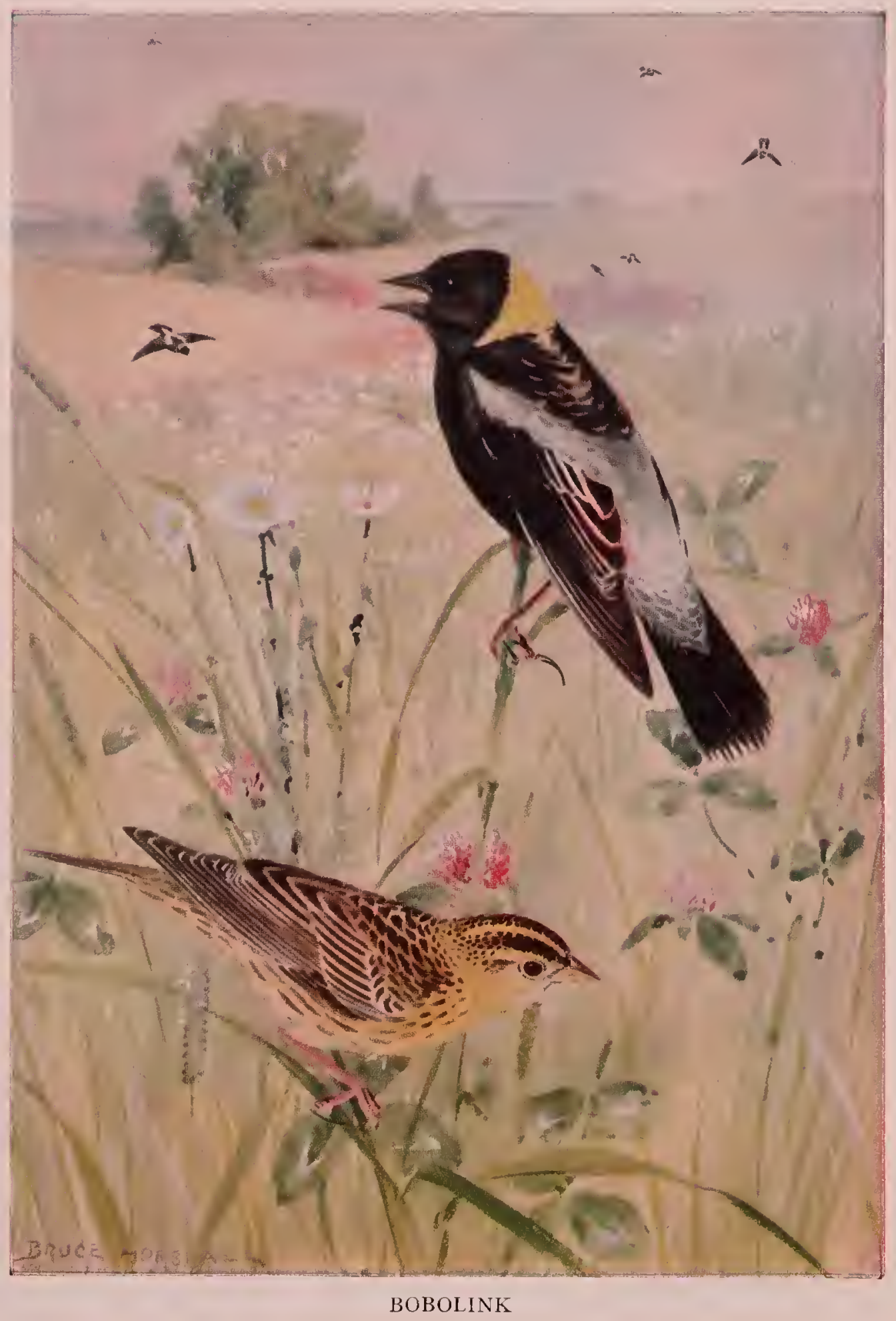



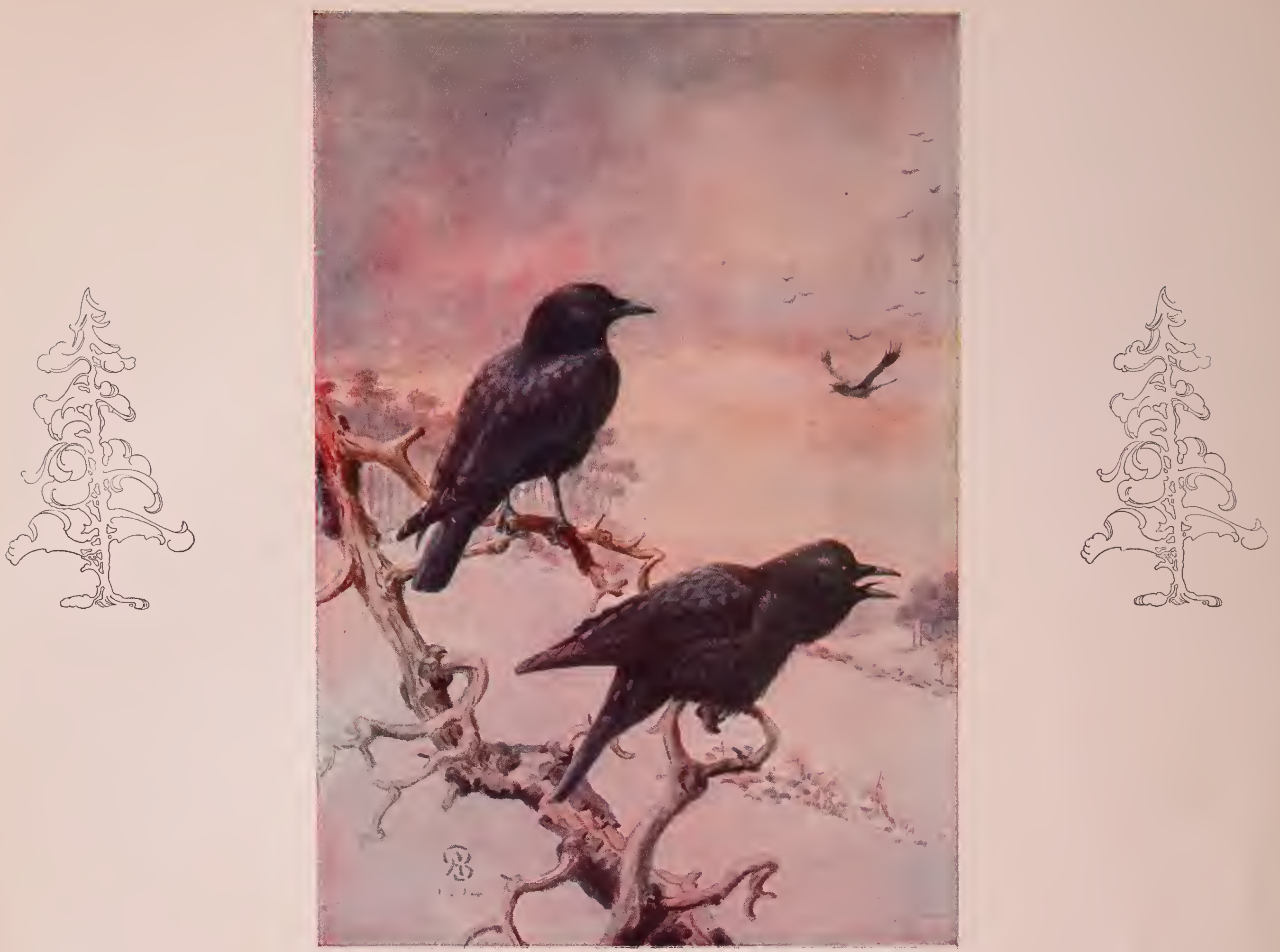

THE CROW

"To the birds' foot race I want to go, As we are full of speed, you know. I hope they let the blackbird in, As one of us is sure to win.

"The Blackbird is my pal, you know, That's the reason I want him to go. We are out in all kinds of weather, As birds of a feather flock together.

"Did you hear the latest, I do declare We are both to have a job out there. As I heard the old Eagle say

He wants black help around that day." 

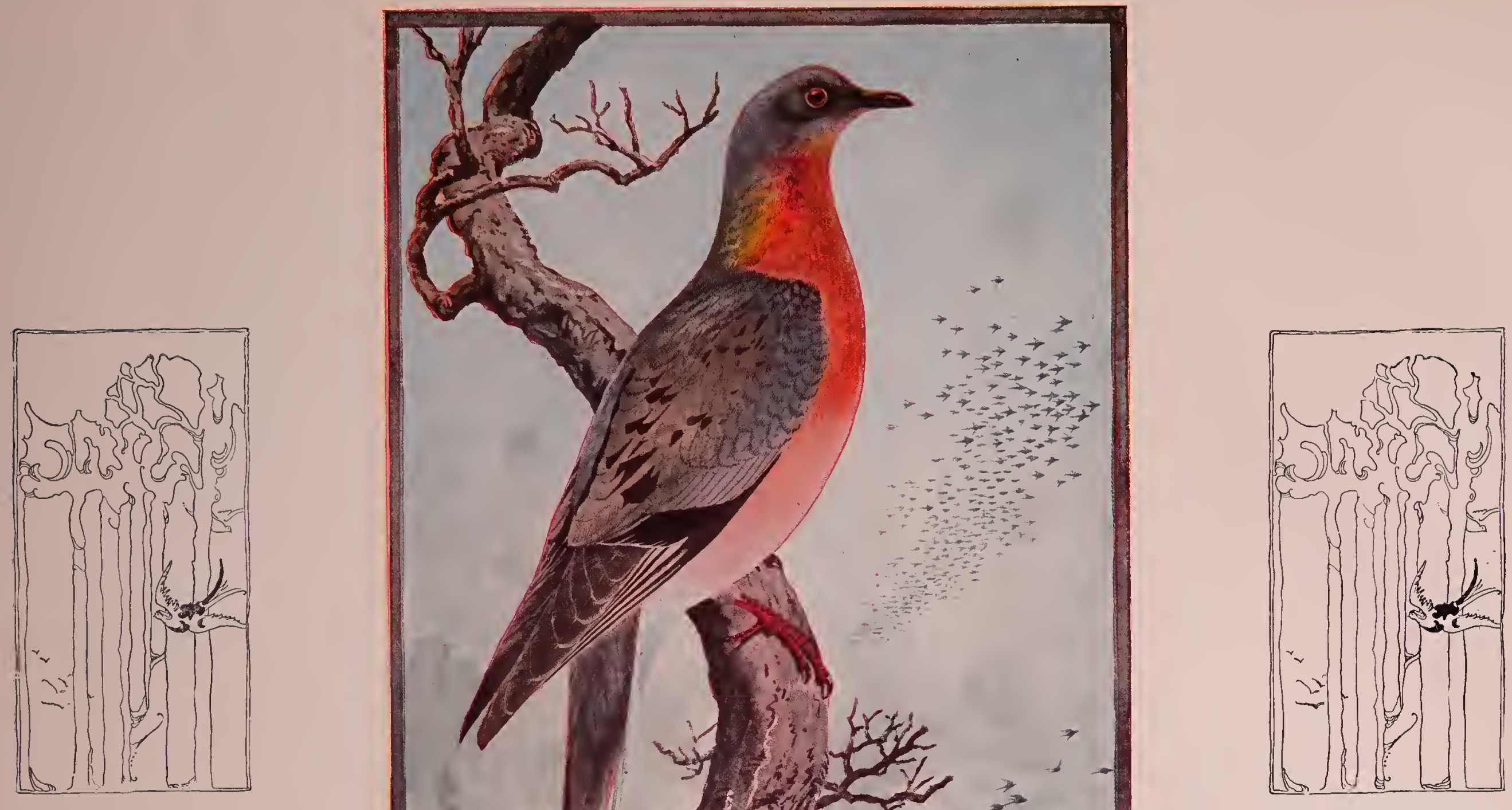

\section{PIGEON}

"Some of the other birds I may have to release As the old Eagle has made me The big chief of police.

"He says keeping order Is just a matter of form And I won't have any trouble In my new blue uniform.
"The most I do, anyway, Is to stand around, look wise, The worst of it all is, I lose out on the prize.

"I'll have some assistant, And one that is right Will appoint the Sandpiper As they all say he can fight." 

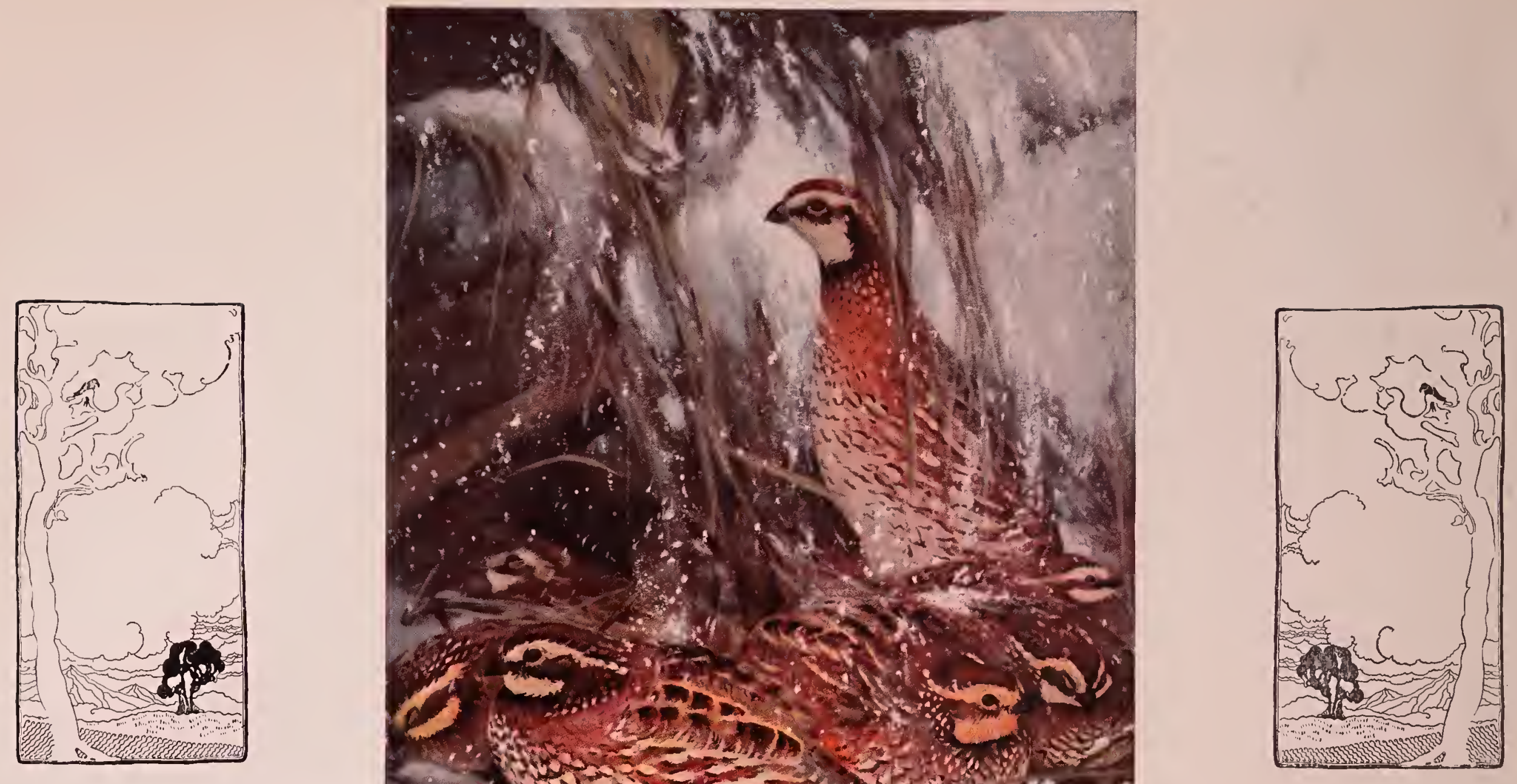

\section{BOB-WHITE}

"I'm noted for speed when I run on the ground, Around barns and hedge fences usually I'm found. I'm a favorite of sportsmen when out on their boast, When caught in their trap-nets they serve me on toast.

"To hide myself I grab up some leaves, And turn on my back, then I am at ease; The hunters pass, or the man with a gun, Always expect that I'm still on the run.

"I'm out in the morning as soon as it's light Hunting my food and my song is 'Bob-White.'

I nest in the bushes in some quiet place

Where I can leave my babies and go to the race.

"That birds' foot race will be lots of fun, For birds like me are good on the run; I'll do lots of practicing before I begin And the best of it all is, I am going to win." 


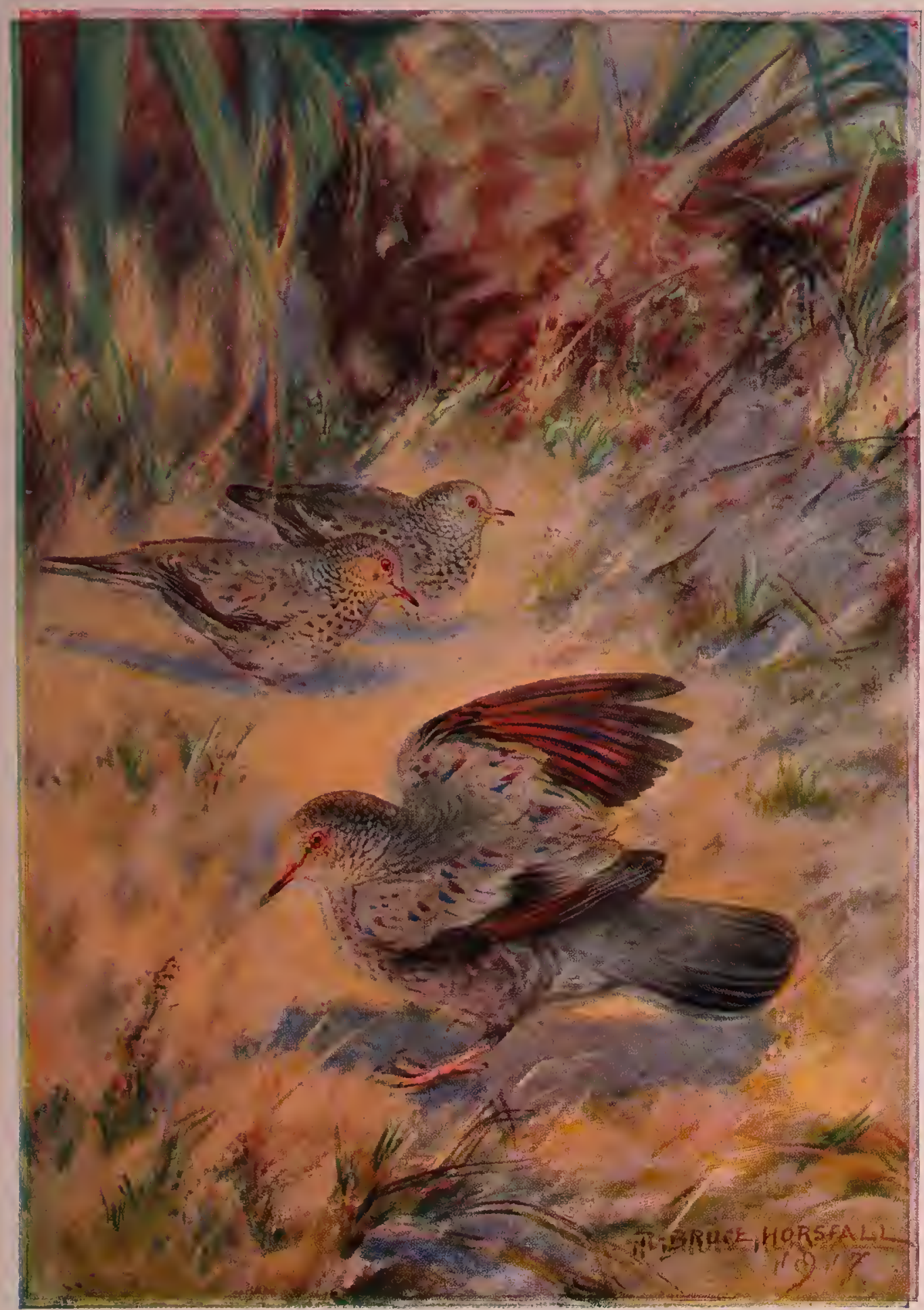

\section{DOVE}

"To go to the race

Would be against my religion, As they might transform me Back to an old Pigeon.

“There'll be lots of excitement, With plenty of fun

To make up a record

Of birds on the run.

"I would like to be there

In a quiet little spot But don't care whether

I enter or not.

"If they have any troubles

They can not release

I will use all my efforts

To help them make peace."

DOVE

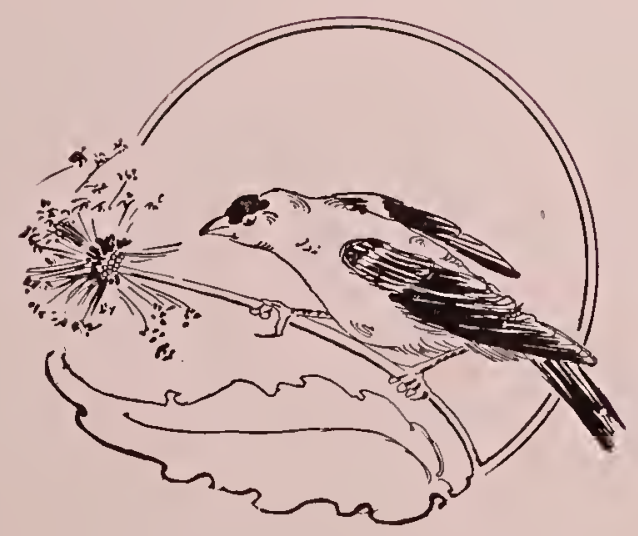



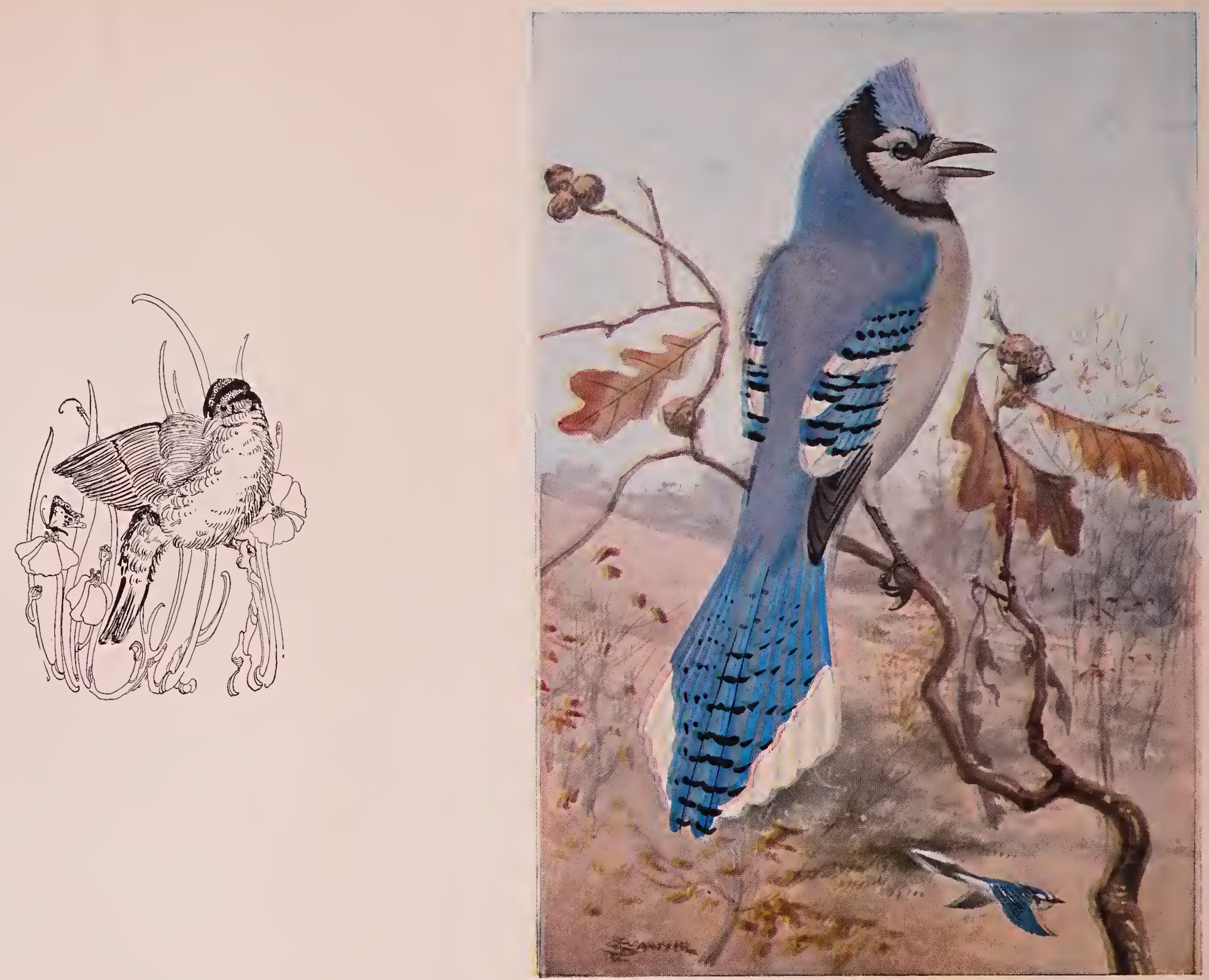

BLUE JAY

\section{BLUE JAY}

"I hear there is going to be a great race.

But we have to go barefoot and at a fast pace.

I bet there will be an awful big throng,

And 'Tain't, Tain't, Tain't,' is my only song.

"My color is gorgeous, my feathers are soft;

But I never could make my home in a loft;

The kids they all like me, that's one very sure thing, But the 'like' is all off when they once hear me sing!

'Tain't, Tain't, Tain't!" 


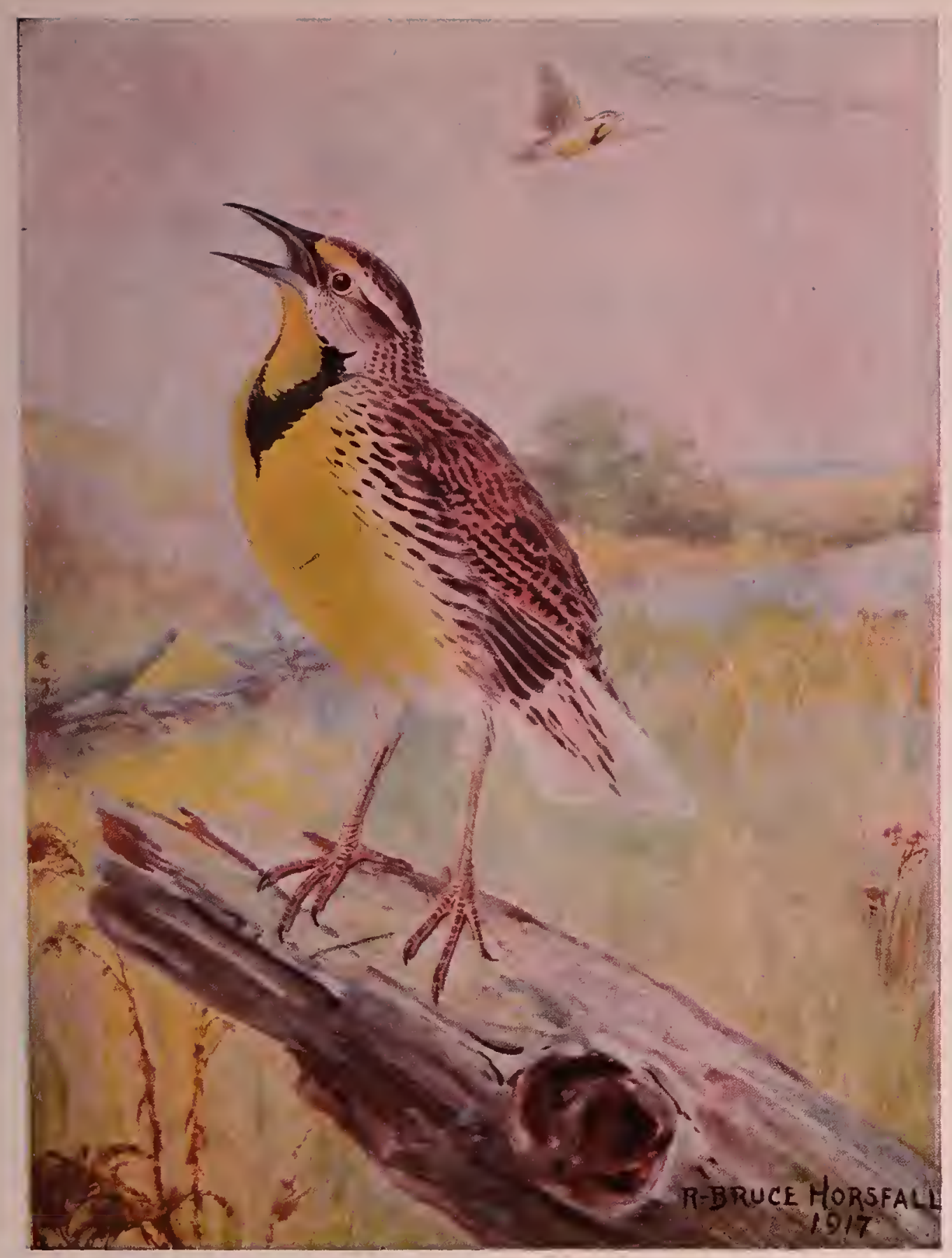

MEADOWLARK

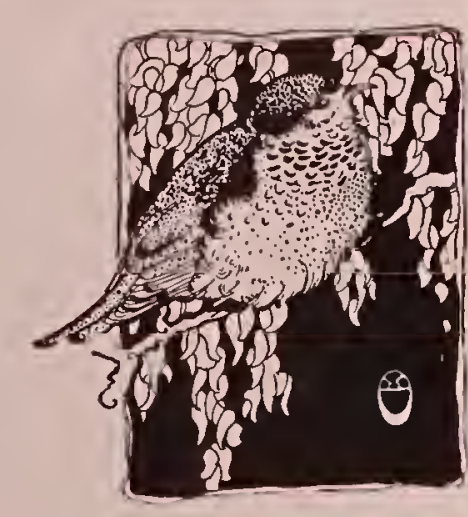

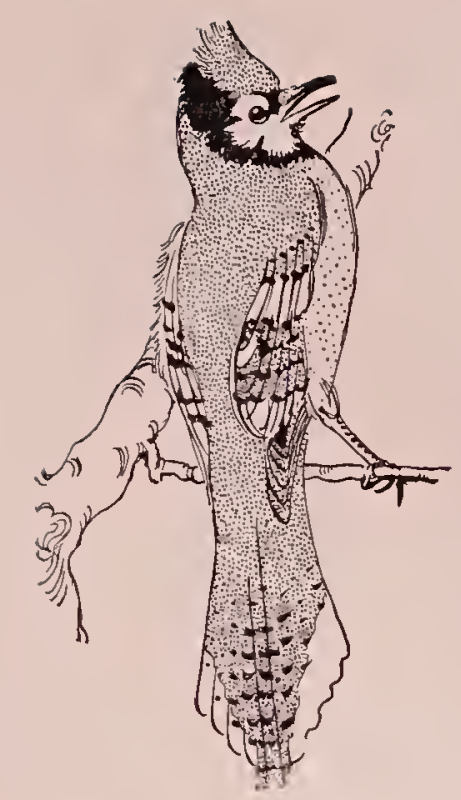

MEADOWLARK

"Hark, Hark, says the Meadowlark, What's that music I hear? The race bells are ringing And ringing out clear.

"I'll be there in the morning Before the races begin, I wonder if they'll let All my children go in.

"I will see the old Eagle, He's always been square, He may let babies in By paying half fare." 


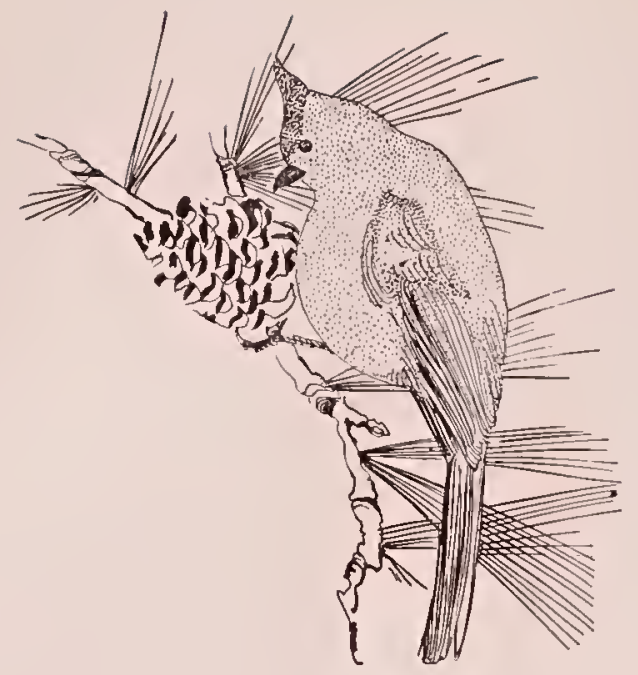

\section{BARN SWALLOW}

"I am known for my beauty As I glide through the air; I'm not much for a foot race, As for that I don't care.

"There's lots of fandangos Each year coming round, But I always get frightened When I'm down on the ground.

"I suppose that good-speed birds Are the ones they are after, I would be much more contented, To stick close to the rafters.

"A foot race for birdies, It will be lots of fun; If the boss birds say so,

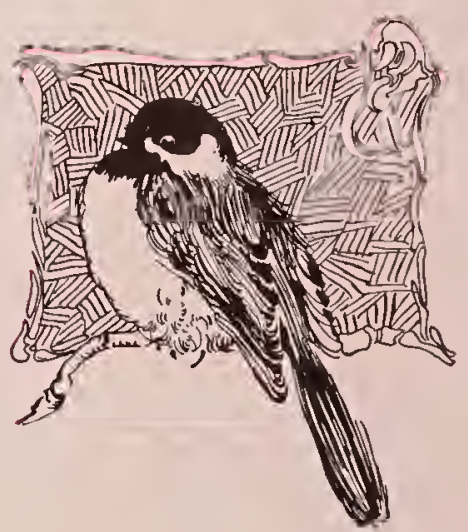

I'll go down and run."

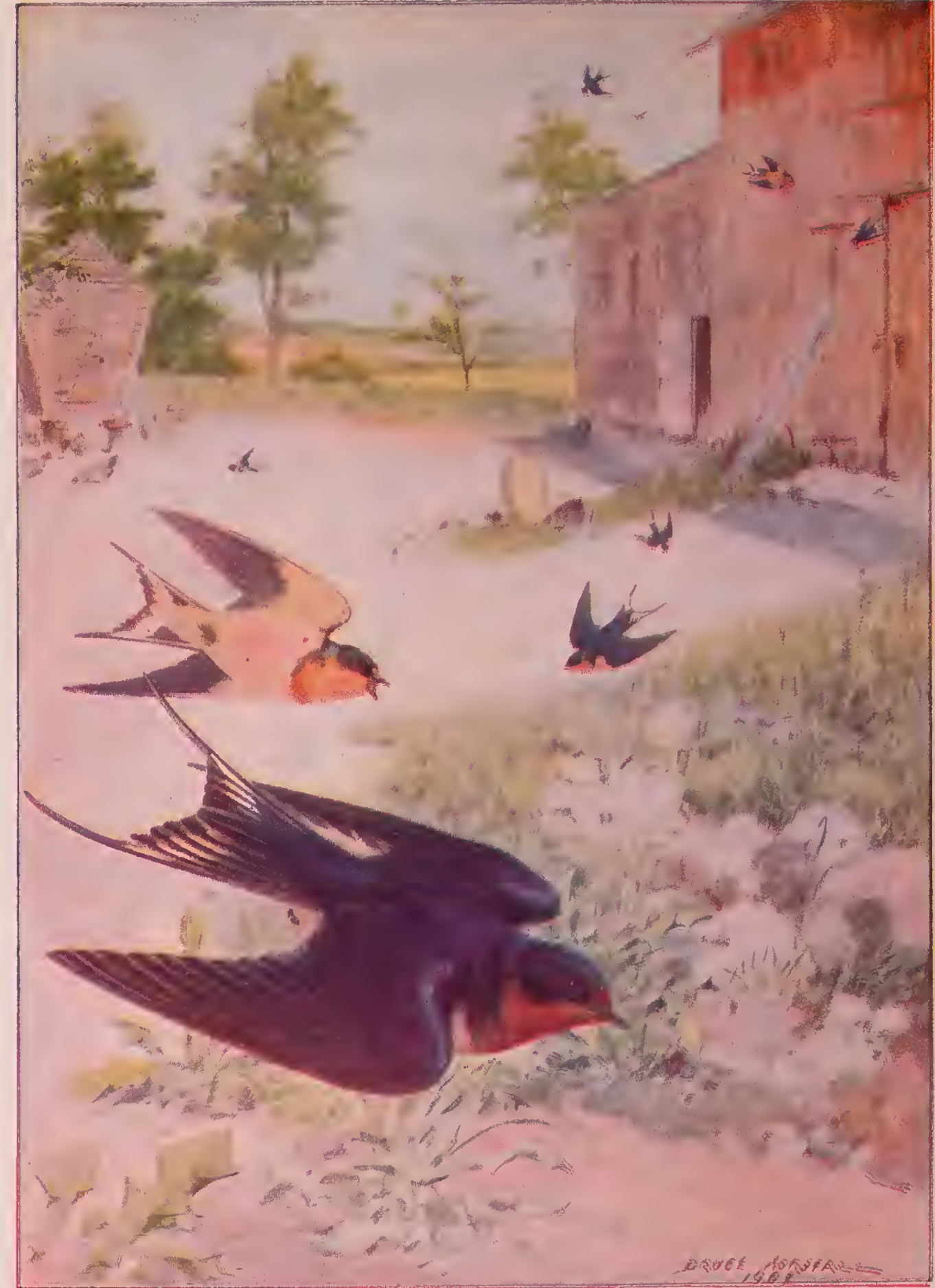

BARN SWALLOW 


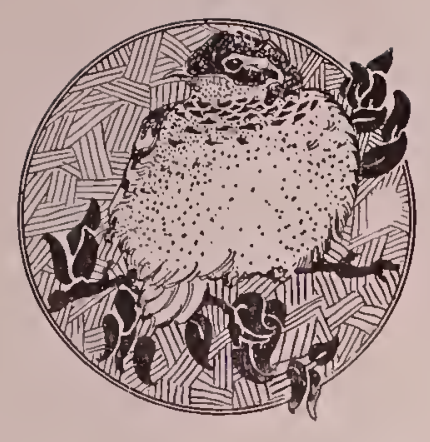

The Western Meadowlark courting the Orchard Oriole.

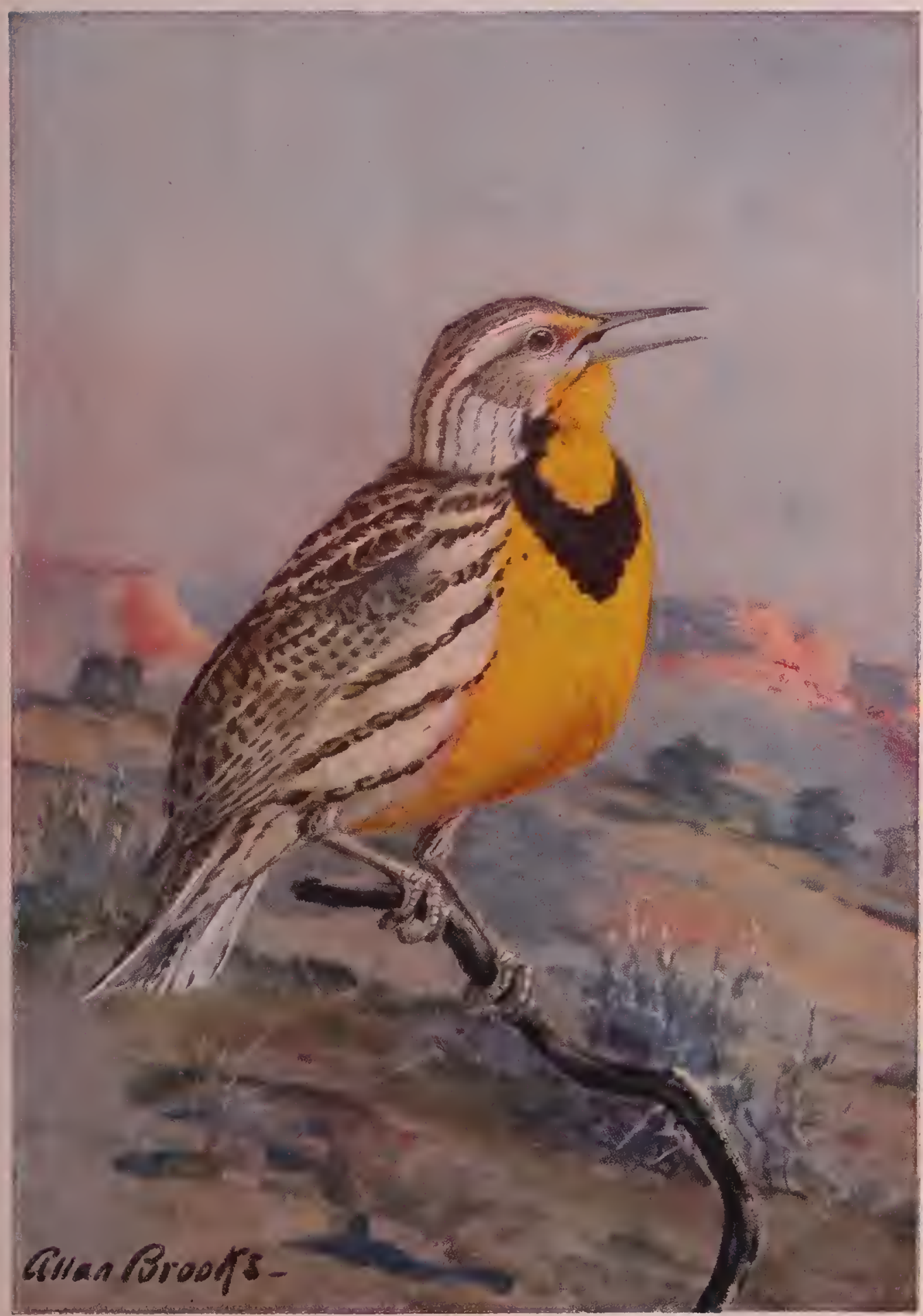

WESTERN MEADOWLARK

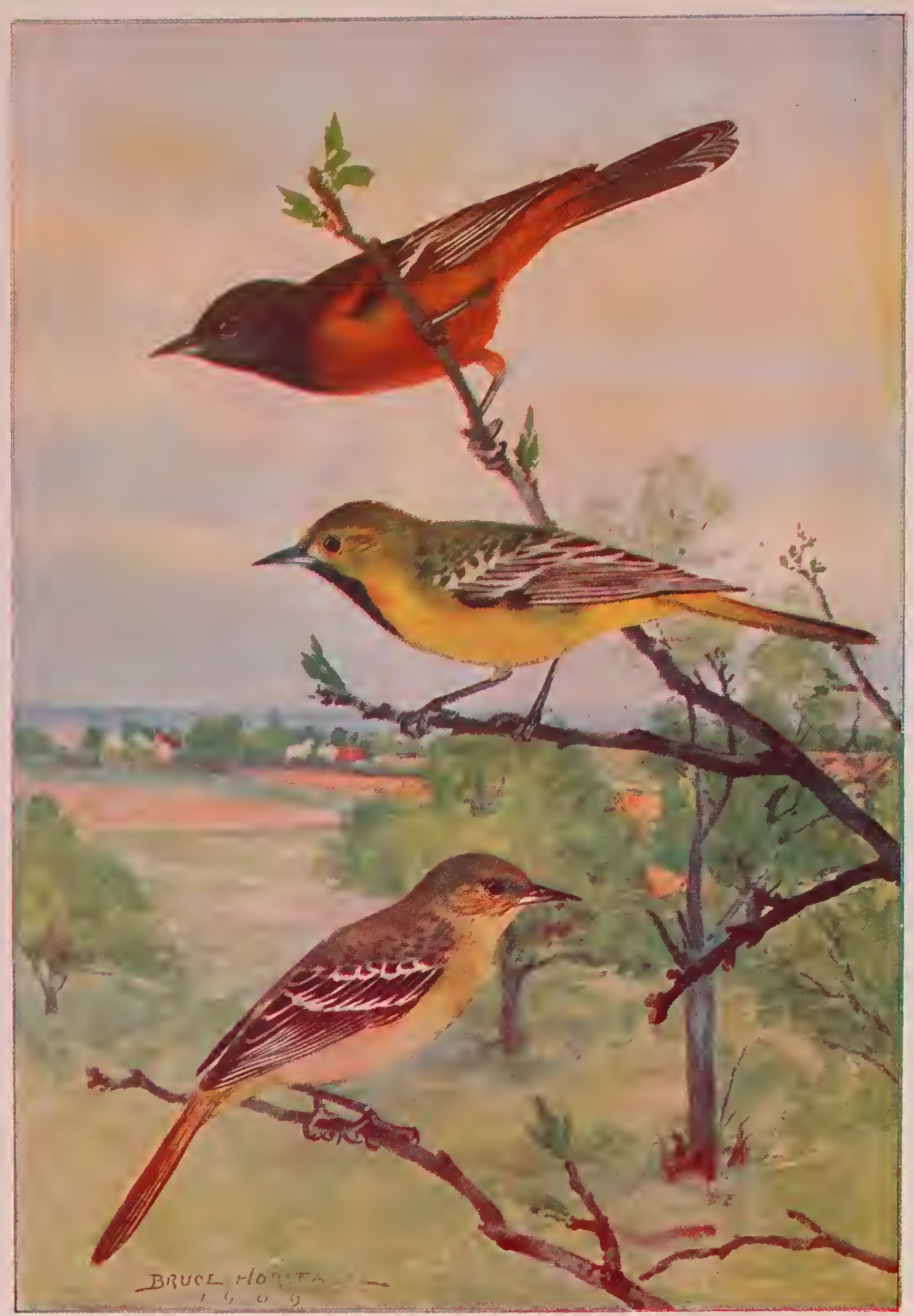

ORCHARD ORIOLE

"Are you going to the races? All birds for to see? I would like to have you To go along with me.

"I would like to see All these birds on the throne But I would rather stay here, Than to go all alone.

"I'm a little bit choice Of my company, you see, And that is the reason, I have picked upon thee." 

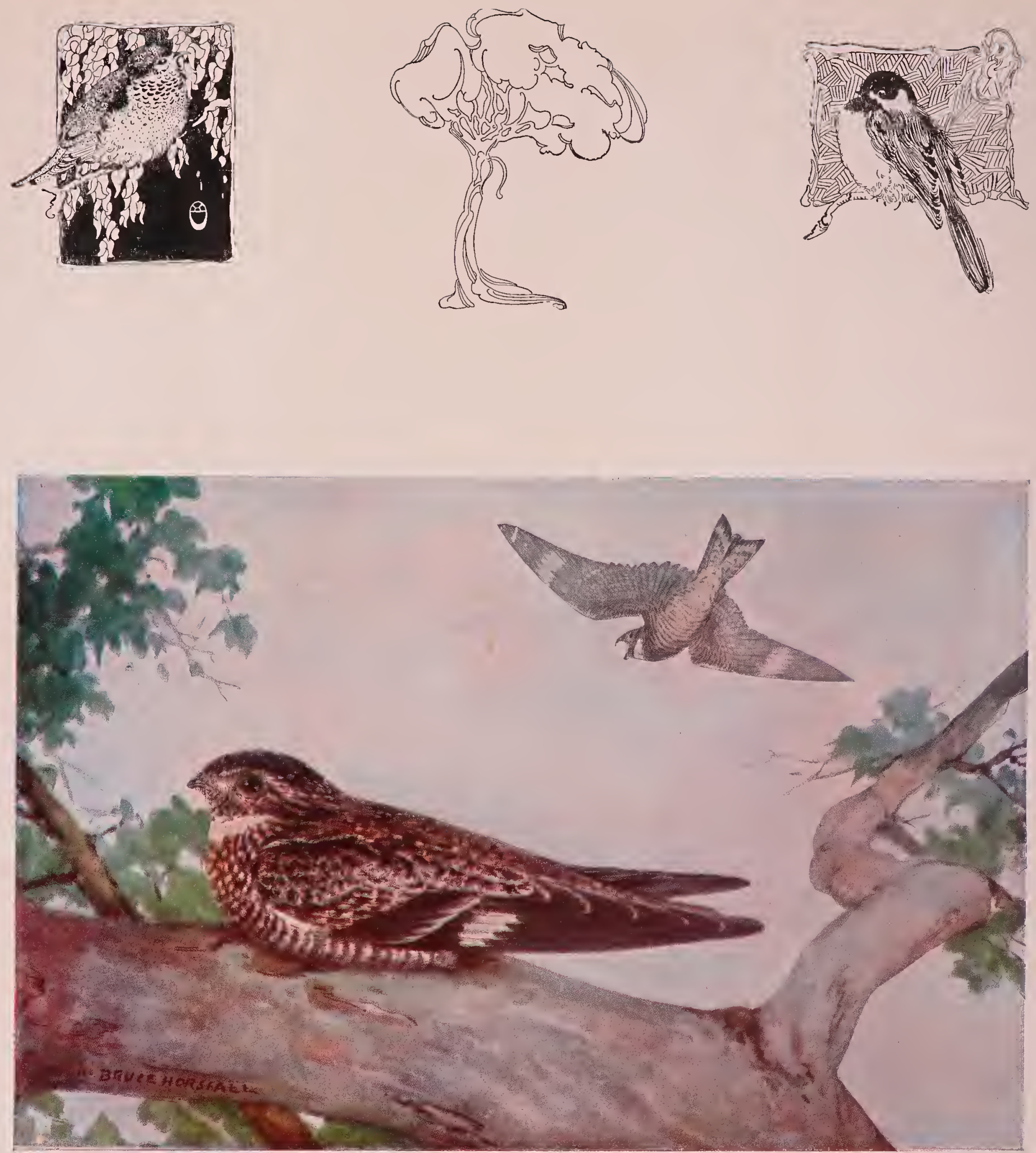

THE NIGHTHAWK

"The old Owl is commenting on me,

That blind old bat, he never could see;

How he even can talk is a wonder to me.

"He steals for a living out of other birds' nests.

So he is most hated by all the rest.

Wouldn't we feel upset if he comes out the best?" 

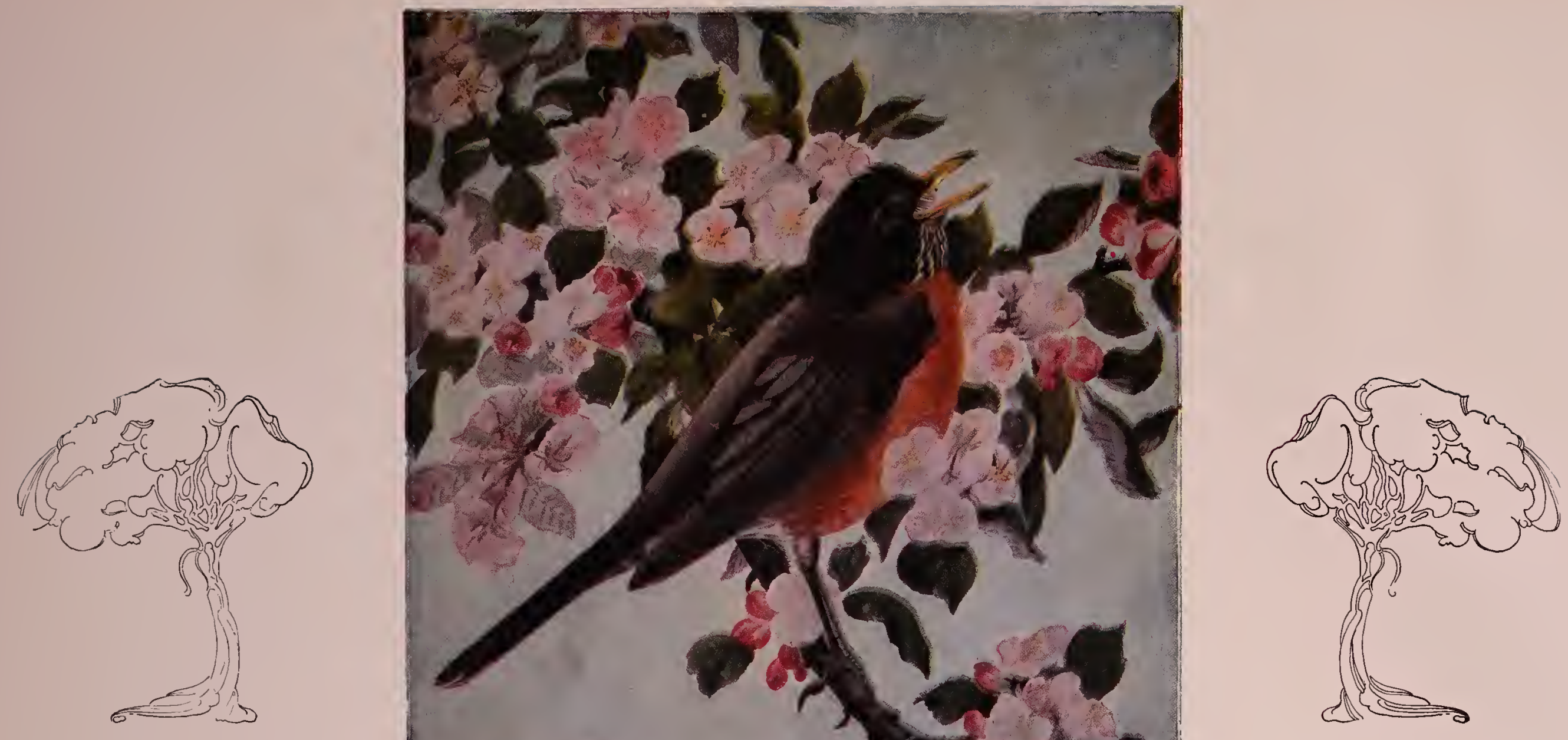

MRS. ROBIN

"In the spring of the year We make the woods ring, It's a sign to the nation The coming of spring

"We build nests near houses Some birds say we are bold; But it's a sign to good children, It's not going to be cold.

"Our main food is fish worms We pull out of the ground In mowed lawns and gardens They mostly are found.
"Sometimes we find big ones, Most too big to eat, But we manage to pull them Apart with our feet.

"We are first to have babies In our dear little place, And I sure want to take them To the birds' foot race.

"For those little babies 'Twill be lots of fun, For mama and papa Are both going to run." 


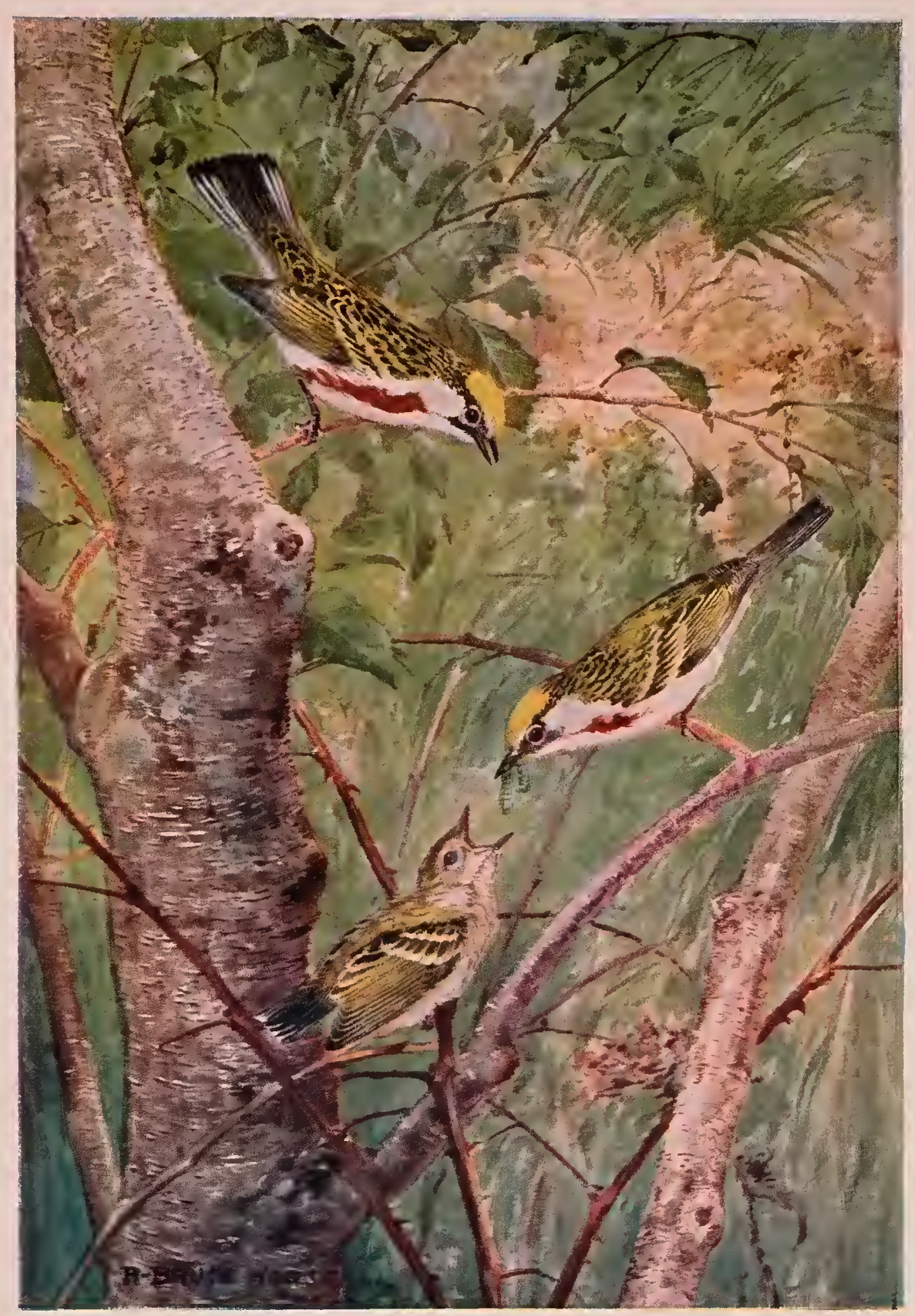

WARBLER

THE WARBLER AND SPARROW

"Shall we leave our home, In this dear little spot To join in the foot races, Whether we win or not?

"Well, come A. V. Junior, With eyes so brown, Let's look up the route To this new race ground.

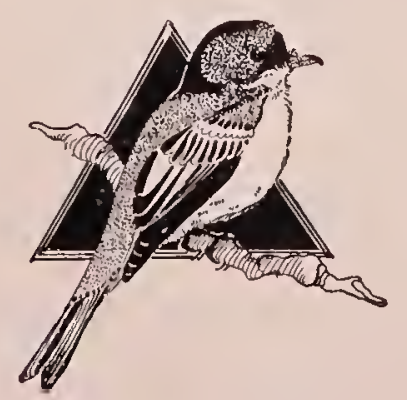

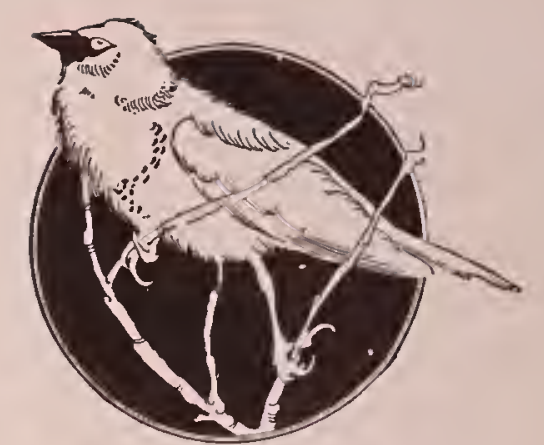

"Our time it is limited, The nests are so sweet It's hard to arrange With birds for a meet

"So let's hurry along We must know by to-morrow, That's not very much time For the Warbler and Sparrow."

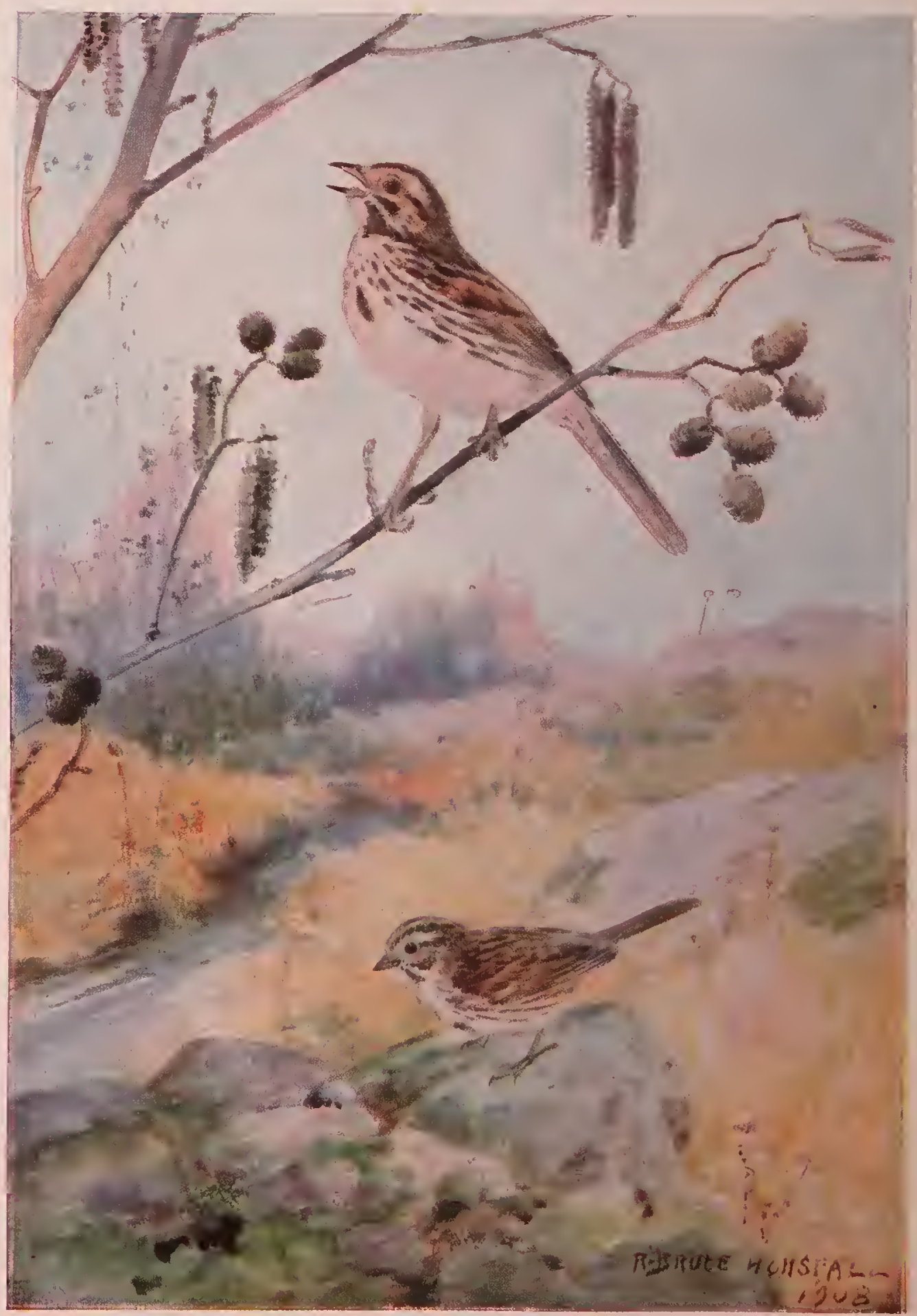

SPARROW 


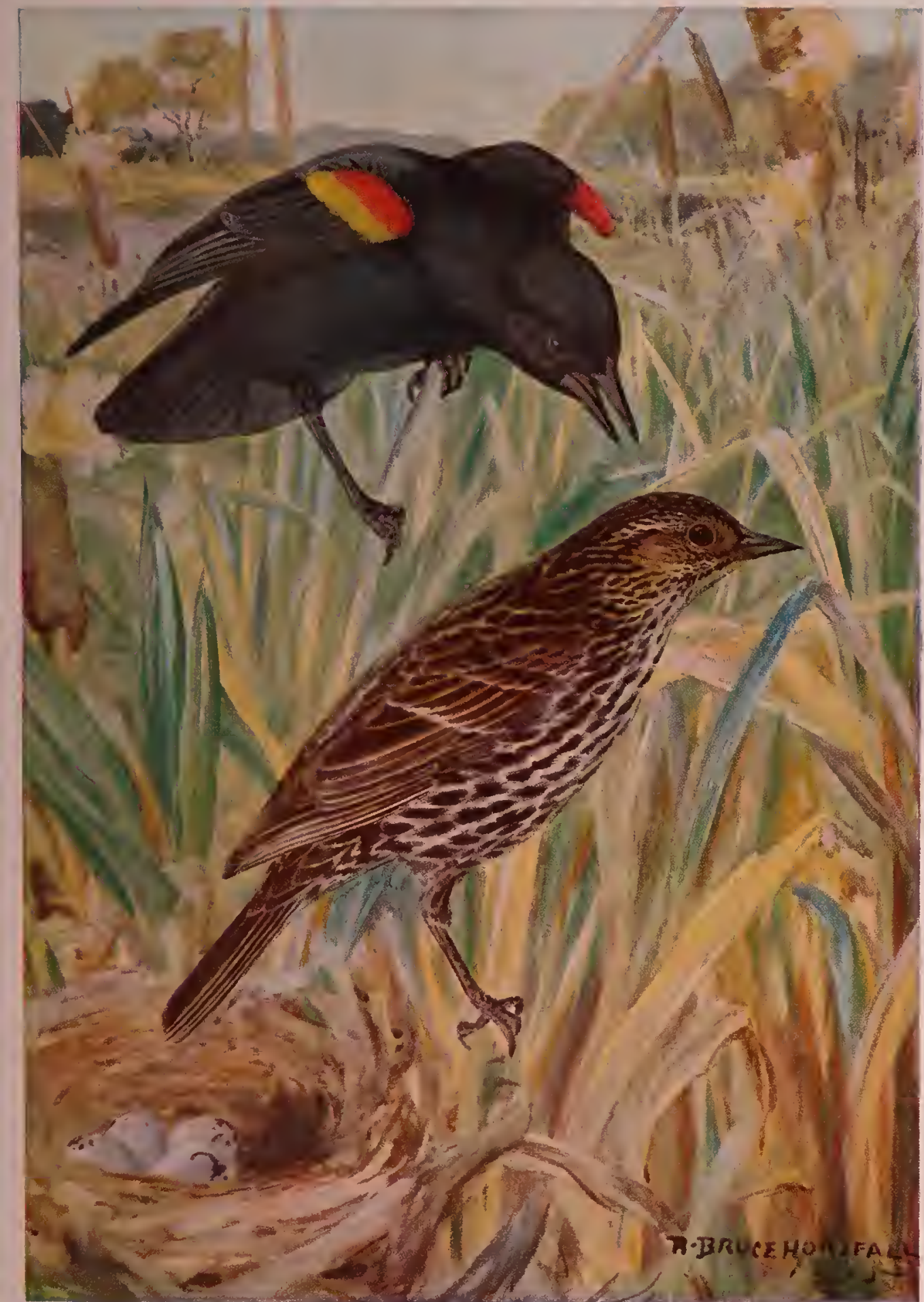

RED WINGED BLACKBIRD

THE RED WINGED BLACKBIRD

"They call me a Blackbird, Yet my wings are red, And about my make-up A great deal is said.

"When I'm at the races There'll be one nice thing: If they need a red flag. I'll just raise my wing."

\section{THE WREN}

"I'm just practicing the music That we'll have in the band, Expect it will be heard Over the entire land.

"If they arrange to have radios For the race to broadcast, Our music will be heard By the whole world at last."

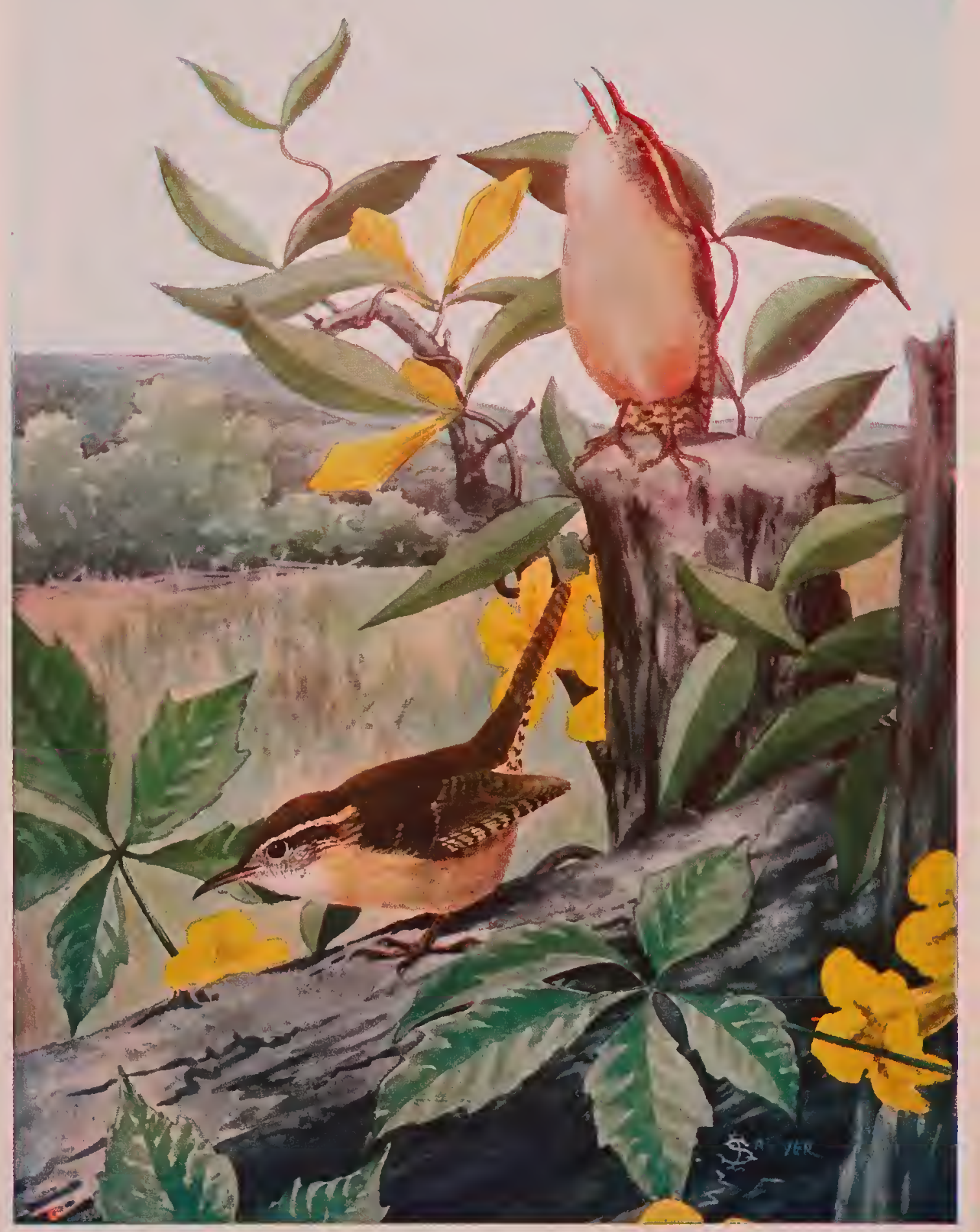

WREN 

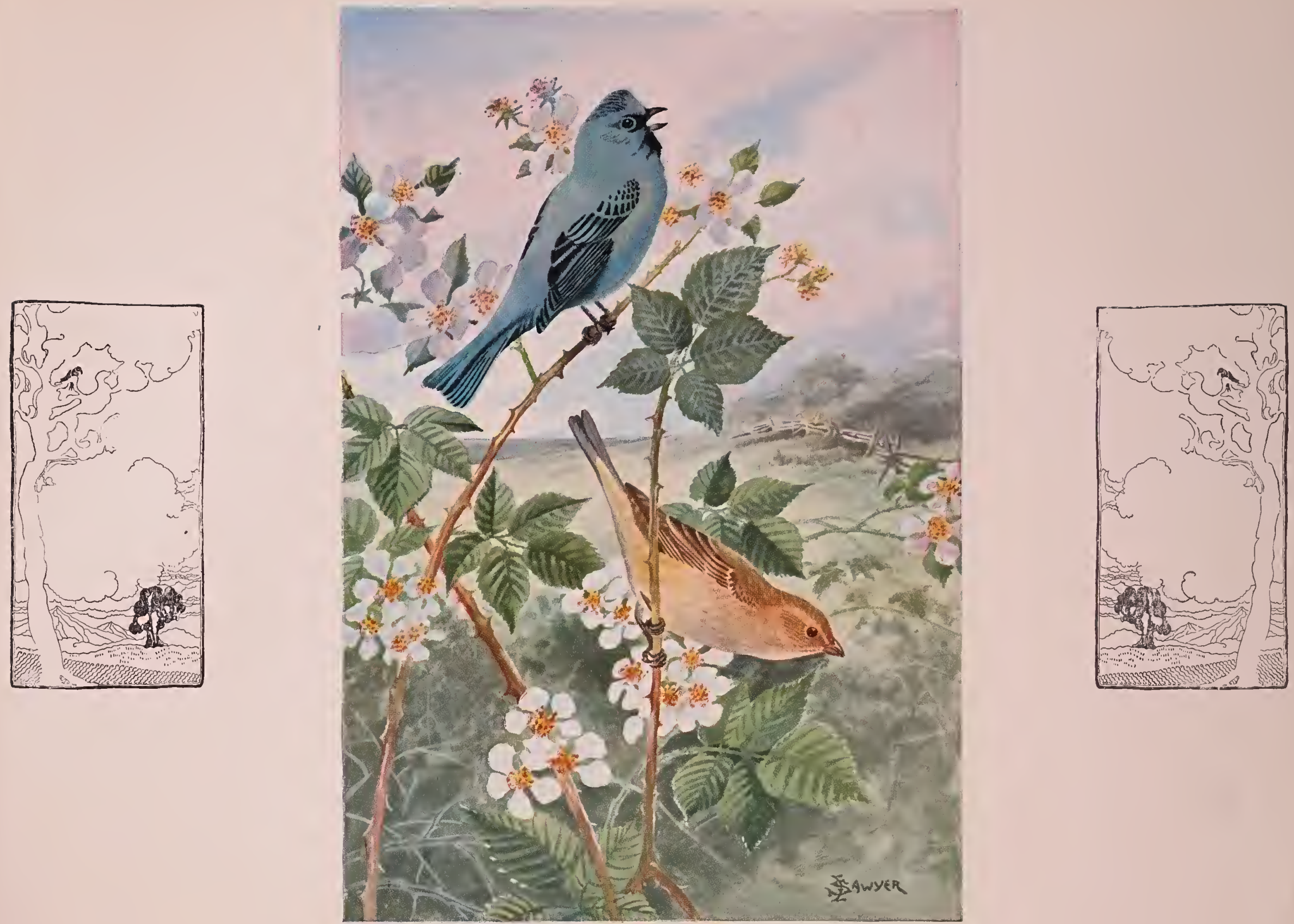

\section{INDIGO BUNTING}

"Che-Wee, Chee-Wee. Che-Wee," singing up in a tree, Marguerite says, "Mama, come quick and see The pretty little birdie is looking at me.'

"Chee-Wee, Chee-Wee, Chee-Wee."

Says Marguerite to Mama and Papa, too

"Do you think that little Chee-Wee Bird will do To have a very little quiet place

In Grandpa's book of the birds' foot race?" 

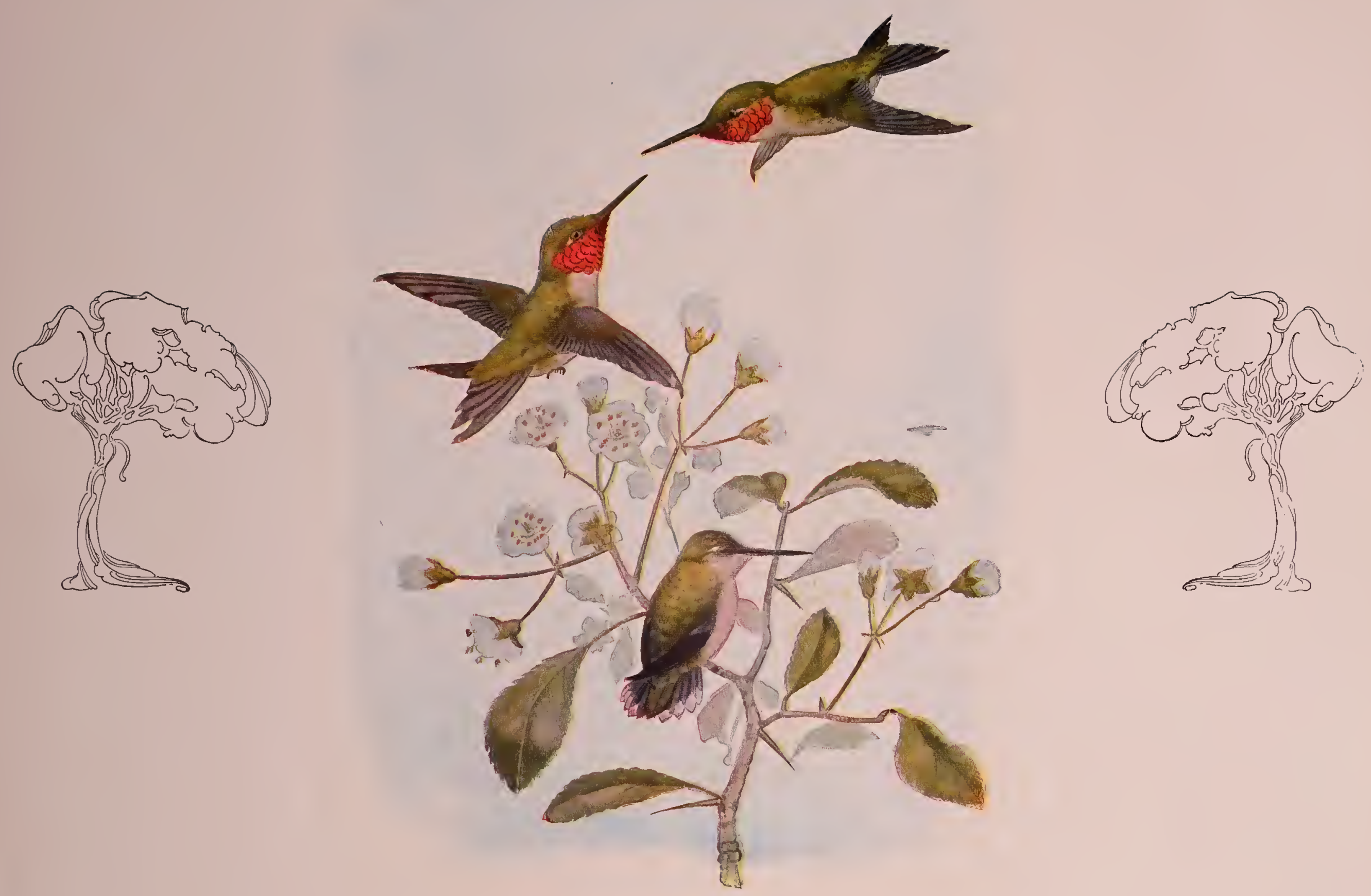

\section{THE HUMMINGBIRD}

"Do you think it would be out of place For me to enter the birds' foot race? To win it would be easy, you see If I only had the entrance, fee.

"Birds can't have just what they choose, But I might get in on carrying the news. You see I am small and not very fat I might get something to eat out of that." 

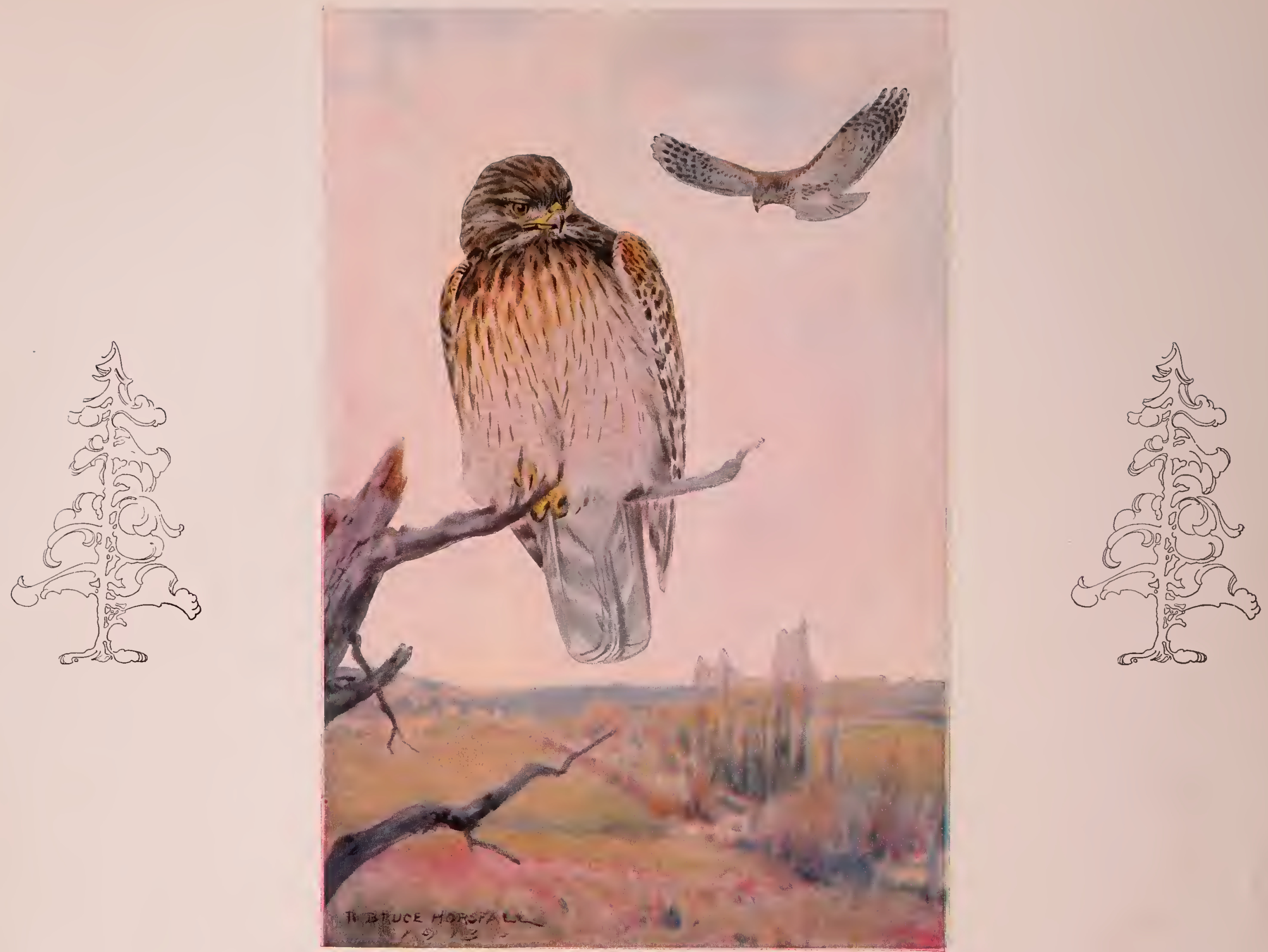

THE HAWK

"I soar high up to the skies,

And keep close watch with my good eyes;

When there's a field mouse down below,

That is when I soar so low.

I do like the mouse's meat

It keeps me looking so sleek and neat.

"'The birds' foot race I want to see.

I wonder what the prize will be.

The race I don't know much about,

And don't know where to find it out.

I'll fly to Bird Town and see

What the program is going to be." 


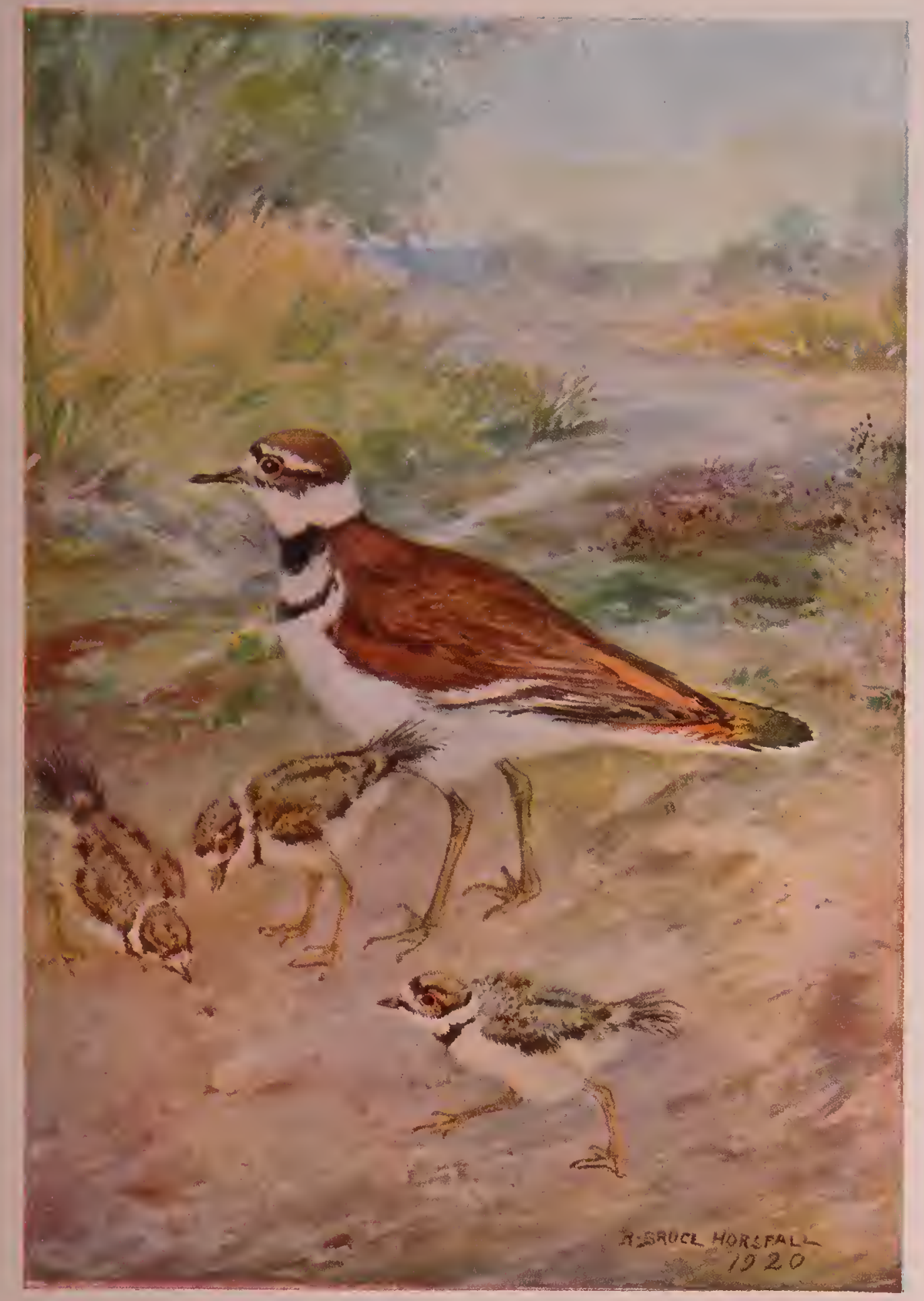

KILLDEER

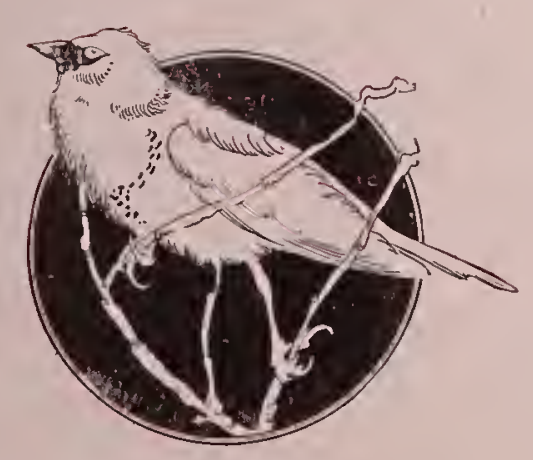

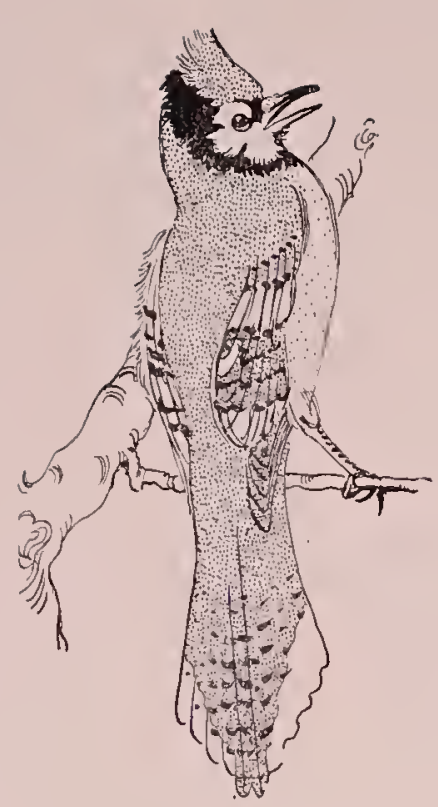

\section{KILLDEER}

"I could win that race, I have no fear: But you know the habits of a Killdeer, I always pretended that I was lame So to go in the race would ruin my name.

"I look for a hole in the ground to nest, Which is seldom found by any of the rest. I lay four eggs with the pointed end down That's why I prefer to nest in the ground.

"I have already told you my very own name; But not my object in appearing so lame I'm quite sure with me you will agree That by pretending to be lame I get sympathy.

"As for me, I don't think I will wrinkle my face, To wear my sweet little life out running a race, You see I am doubting and can't see the joke, Of getting so dusty that I'm ready to choke.

"Now, good birdie, just take my advice for this once, Don't run in the race and act like a dunce. I intend to be there, to see all the fun, But have no desire to be among those who run." 


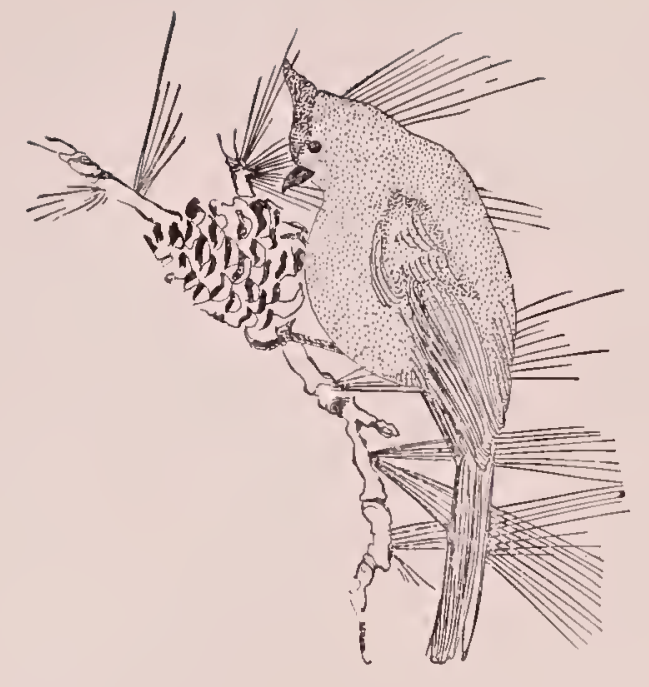

\section{RED-HEADED WOODPECKER}

"I'm a gay-looking fellow, And as gay as I look, I wonder if I can hold My place in this book.

"I never have had trouble

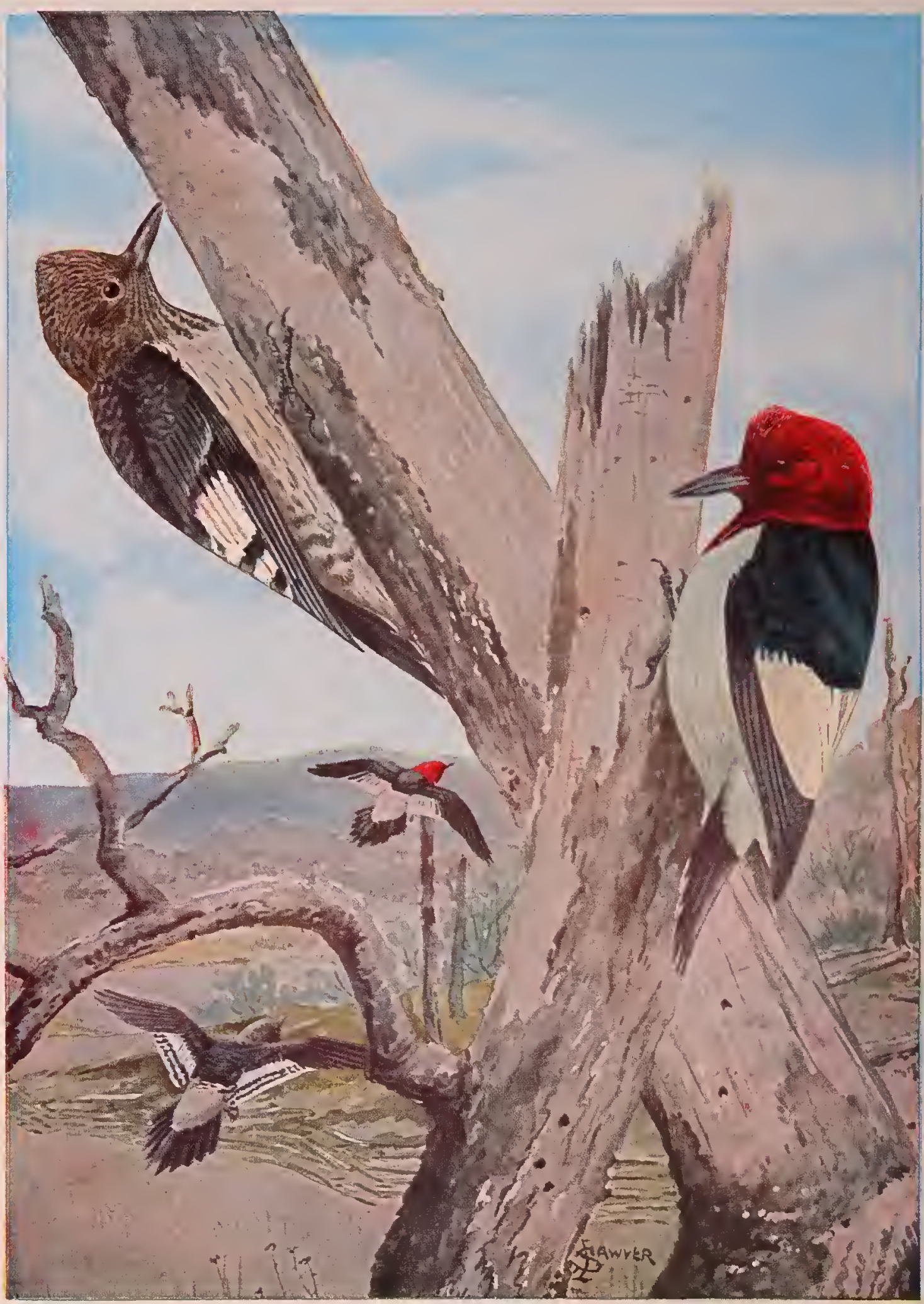

RED-HEADED WOODPECKER

In holding my place,

And don't think I will have

In the birds' foot race.

"Yes, I'm a Woodpecker

But that's no disgrace,

I've pecked and I've pecked Until I'm red in the face.

"For all the small birdies;

They can't make me budge,

As the old Eagle told me

I could assist to the Judge."

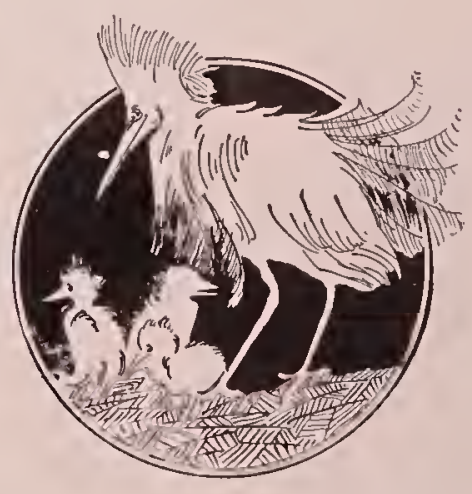




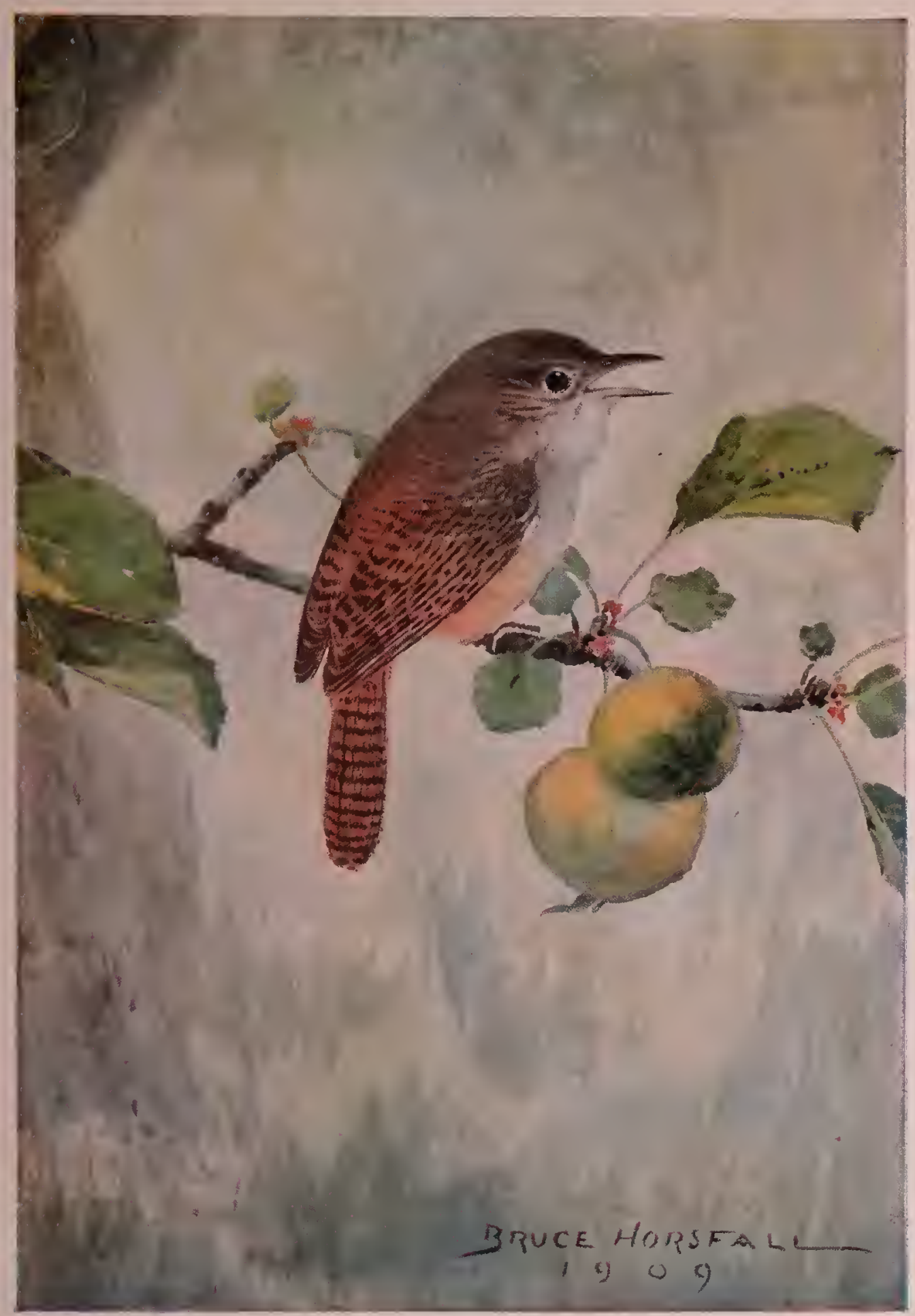

HOUSE WREN

"Do you think I'm big enough to play in the band?"

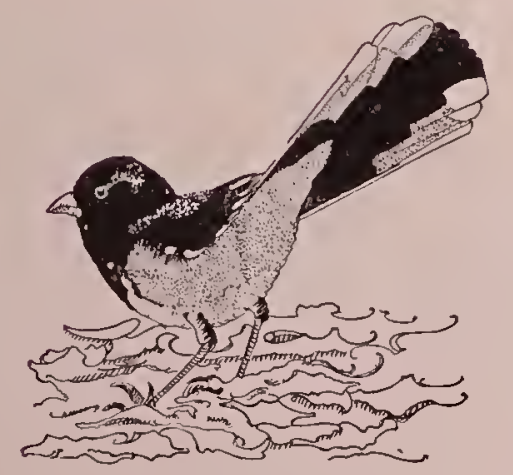

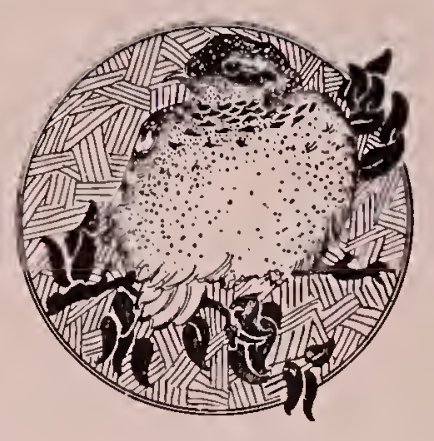

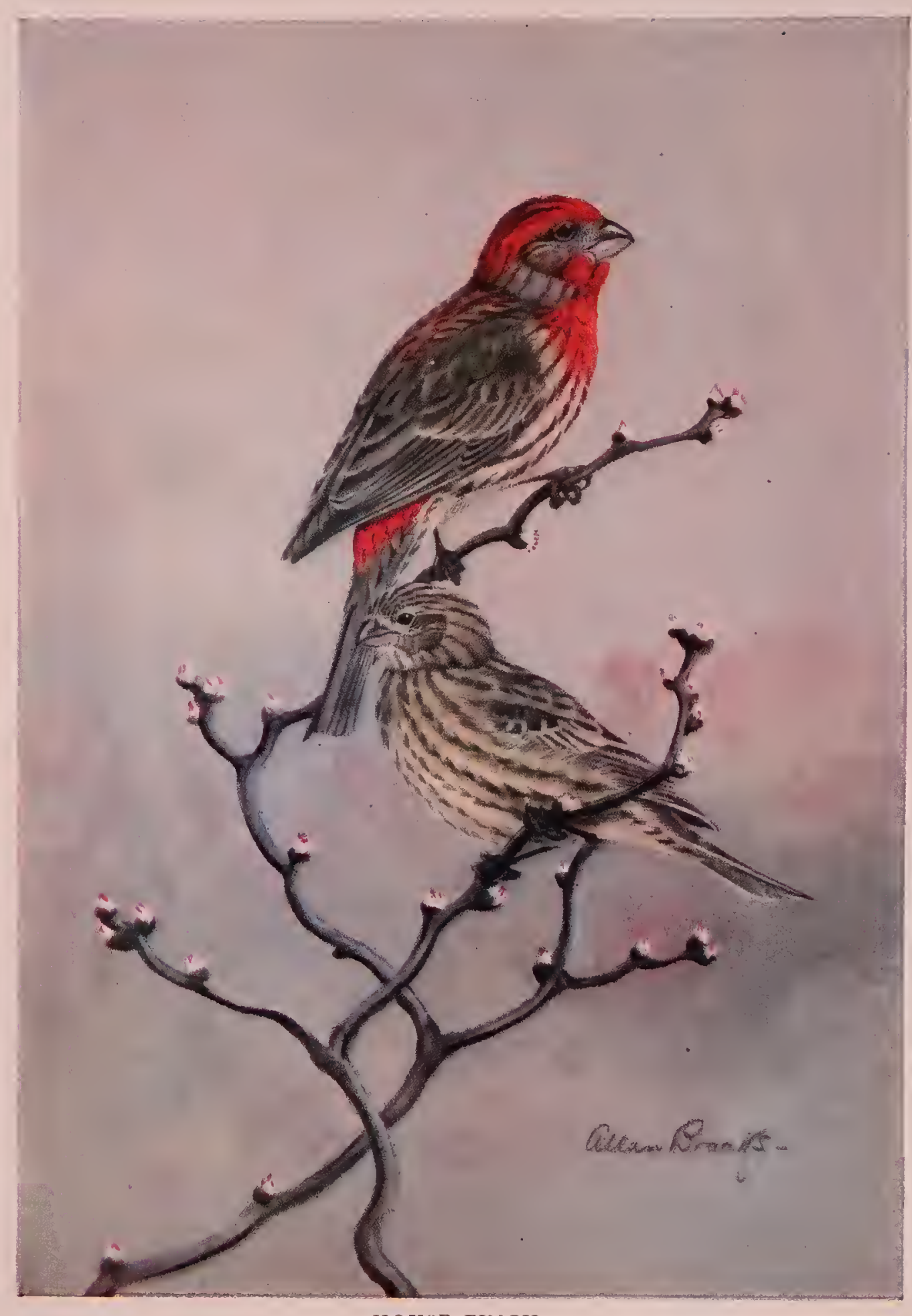

HOUSE FINCH

"This is sure a pretty page, A regular birdland." 


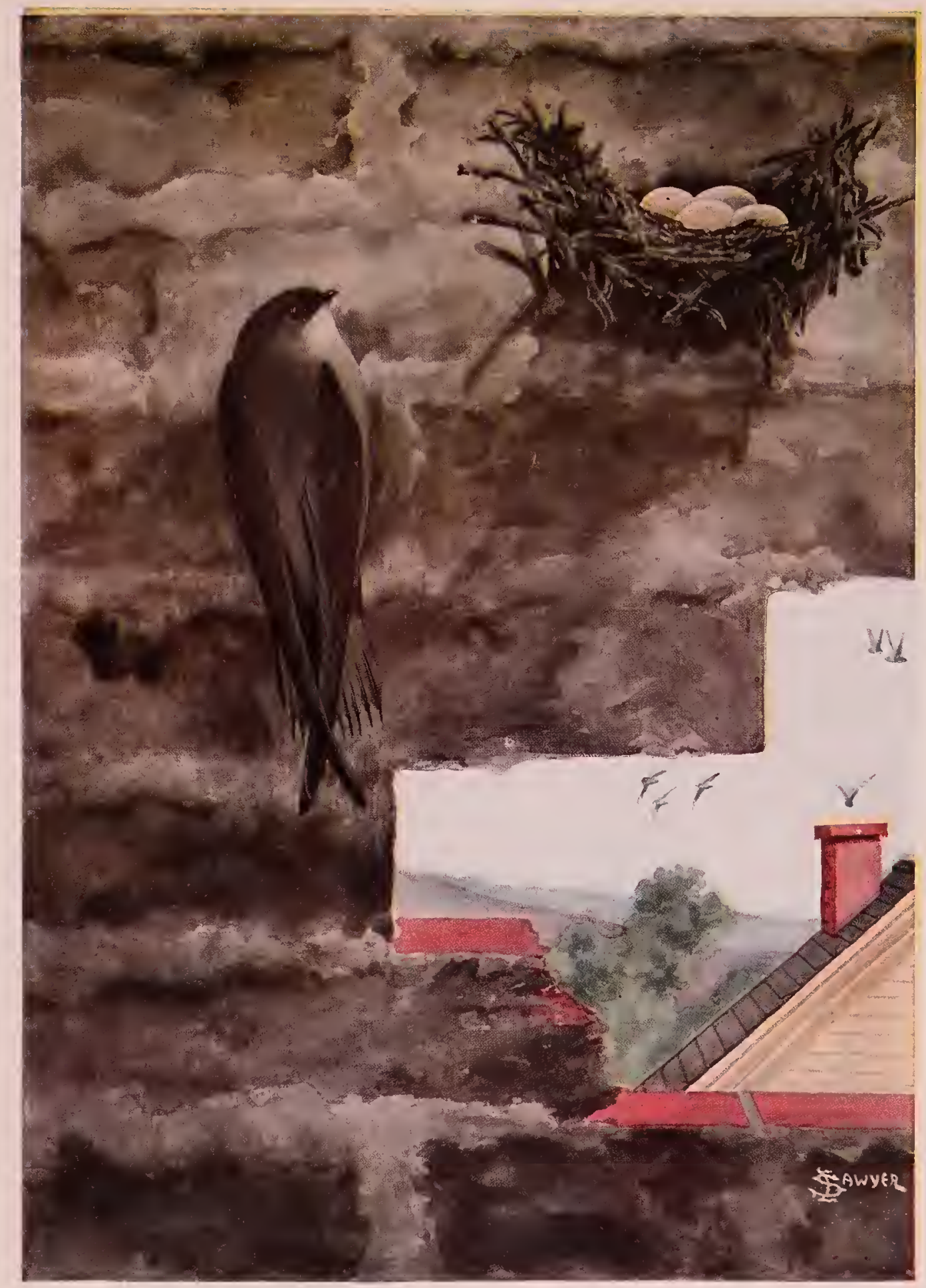

CHIMNEY SWIFT

"I cannot go to the races And leave this pretty nest."

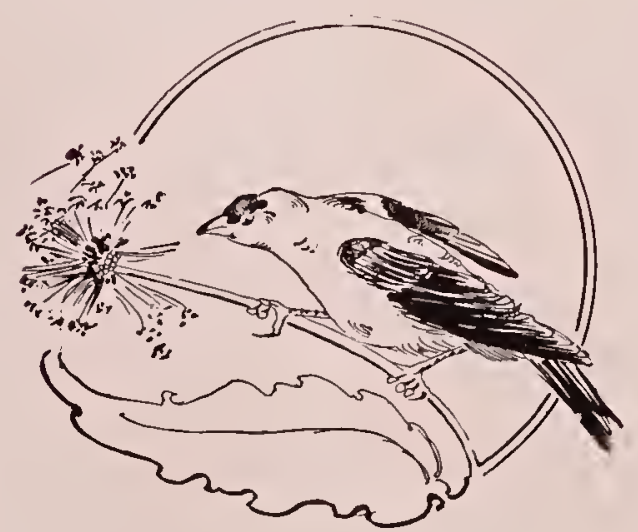

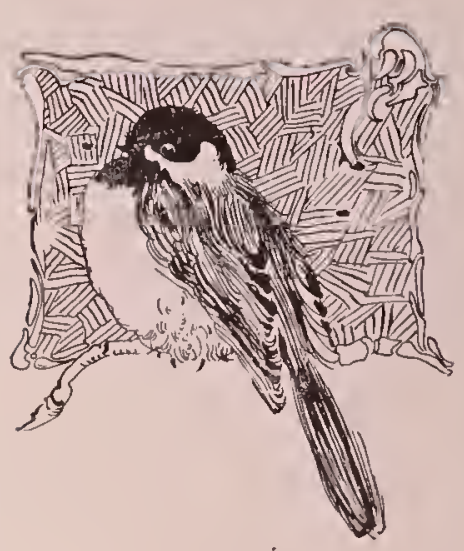

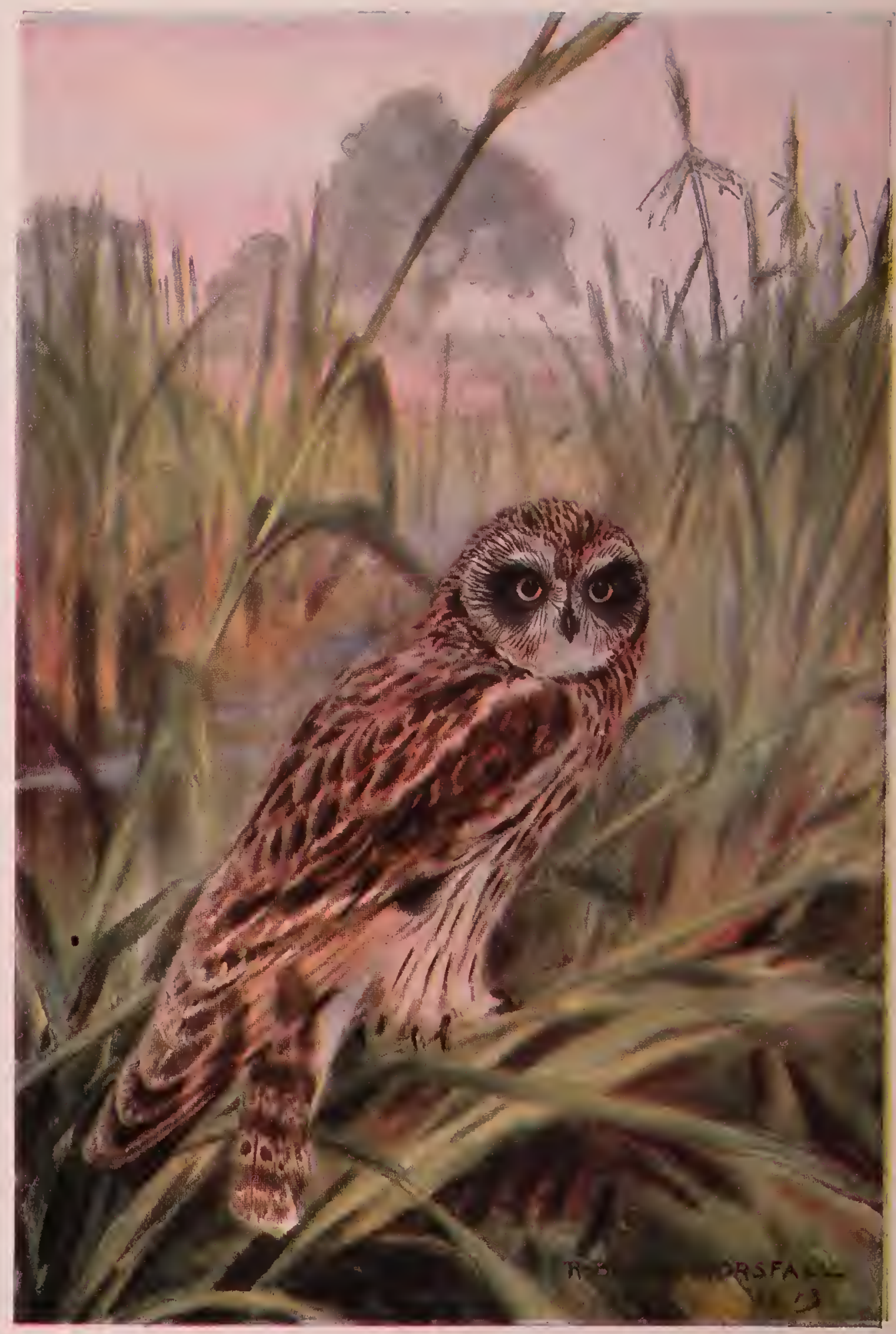

SHORT-EARED OWL

"My mama says I can go, But she don't think it best." 

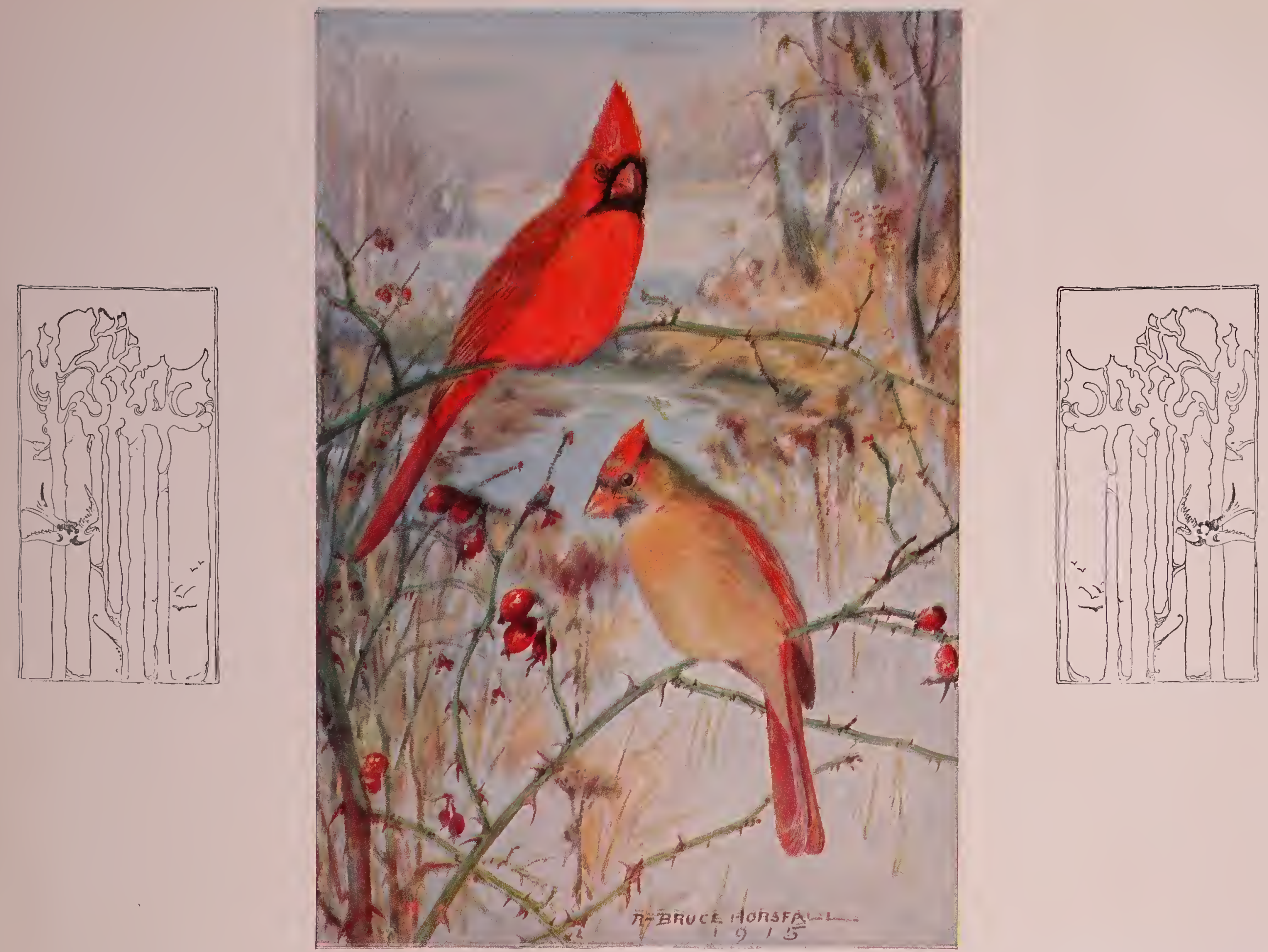

\section{CARDINAL}

"There are birds of all colors, Black, blue, and lead.

I've always been partial

To the color of red.

"It's one colour of our Flag.

The blue is, too,

Which makes up the folds

Of the Red, White, and Blue.

"The Flag we will use,

In some proper place,

To announce the starting

Of the birds' foot race." 


\section{WE PURPLE MARTINS}

'Wonder where the birds' foot race is going to take place?

Think that should be considered in this big race.

Near an Audubon bird lodge would be the best,

Then after the races we could stay there and rest.

'When we are at the races we'll be on the ground;

And at the bird lodges there'll be no cats around,

Bird lovers are not particular about the mice and rats

But are sure sudden death to the bird-catching cats.

"If we stick close to a bird lodge there's plenty to eat;

We need not worry about being thrown out in the street,

Bird lovers feed us on sweet cake made from honey and grain

And all birds that play at bird lodges get treated the same.

"Song birds as a hobby, it would sure make you laugh;

There are many places in bird lodge to feed and to bath, They also have shelter houses that I cannot explain Just the thing for birdies to go in when it rains.

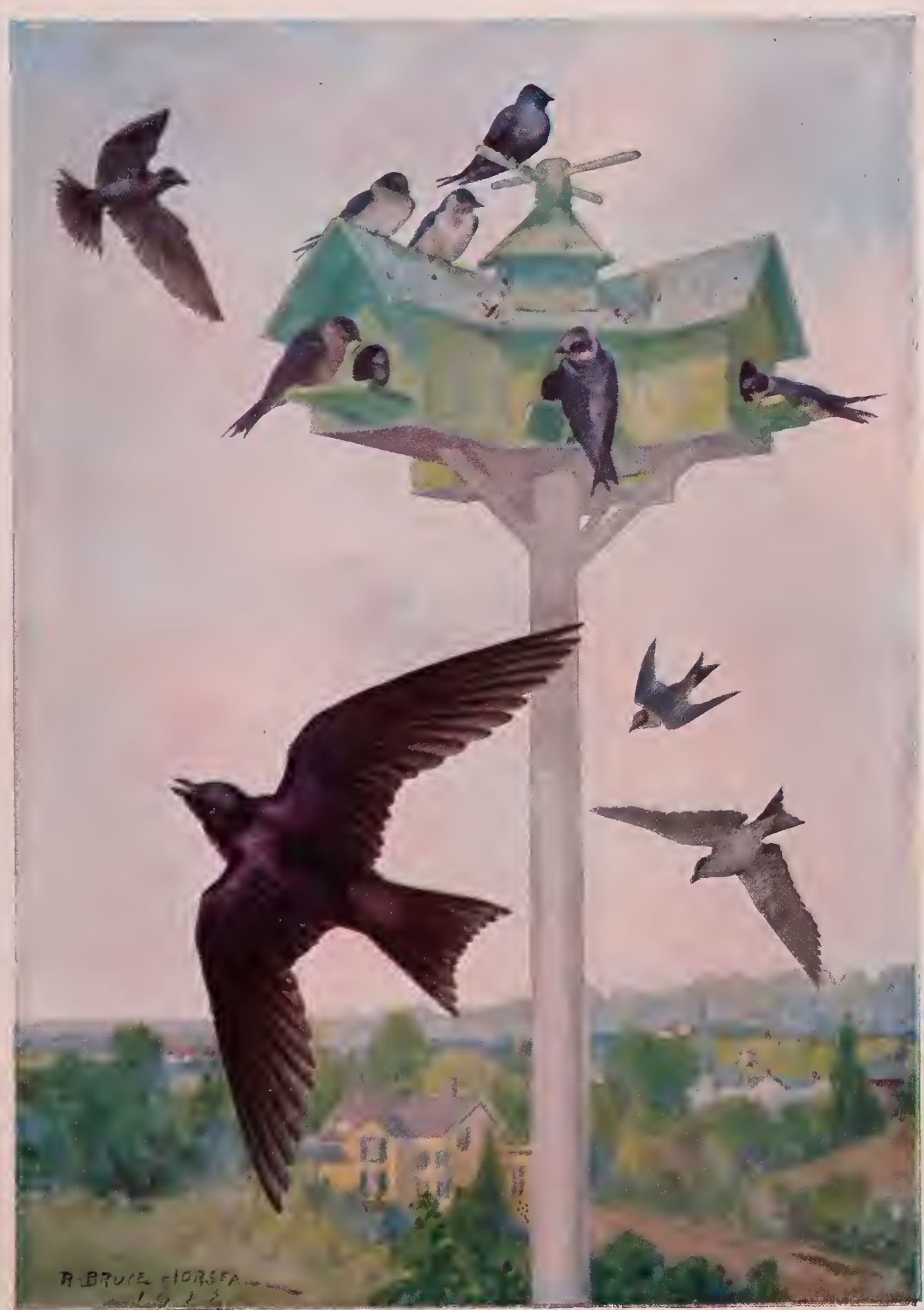

PURPLE MARTIN
"We Purple Martins are fond of the bird lodgment And with all other birds that chatter and sing We go to the far south in the cold, cold winter But return to the bird lodgments each spring."

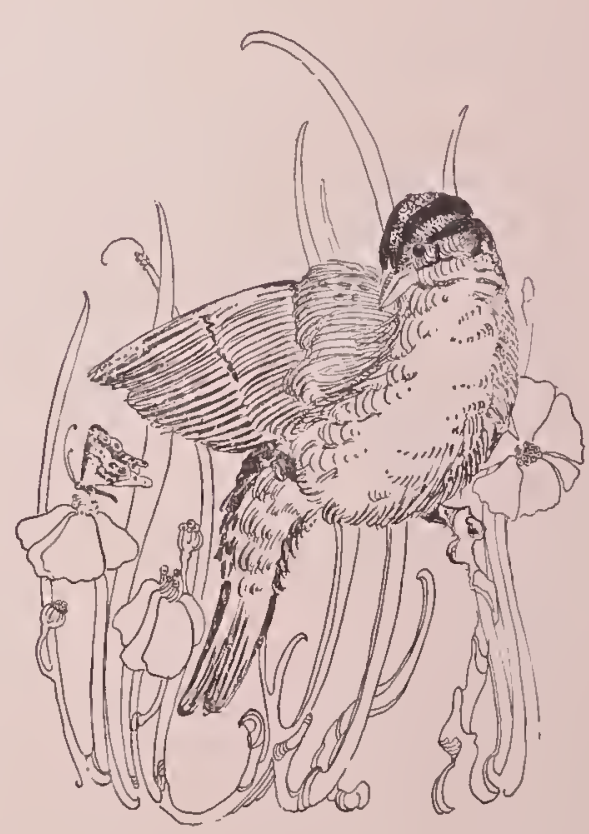




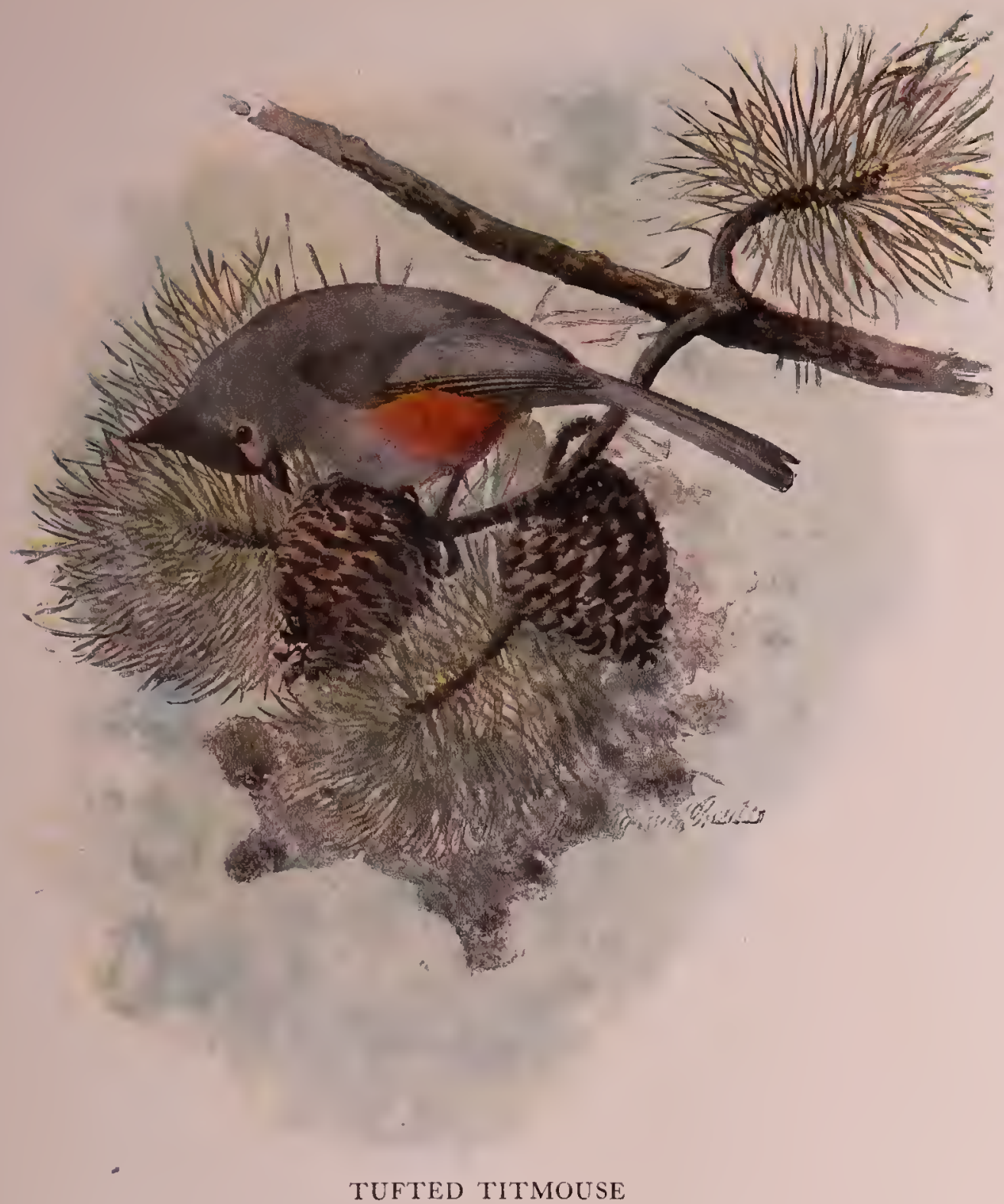

TUFTED TITMOUSE

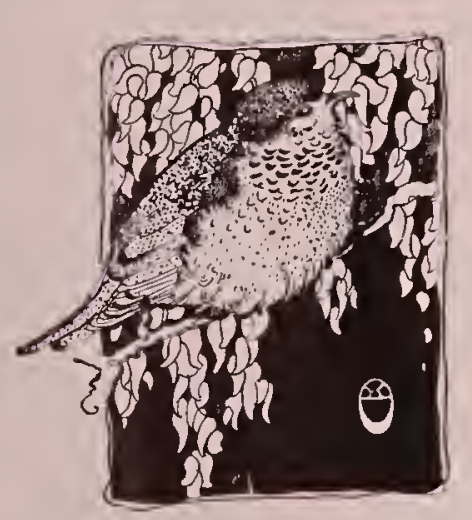

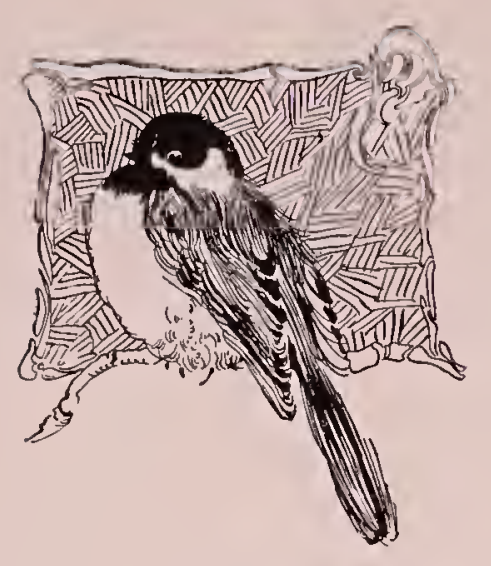

"If I find what I am looking for I will have something to eat. Don't you think my pose and color Are both very neat?

"I am going to the foot race Arranged for the birds If I can't get first prize Will try to get third.

"If I lose out on all prizes I will still have my house Which is still very good For a little Titmouse." 

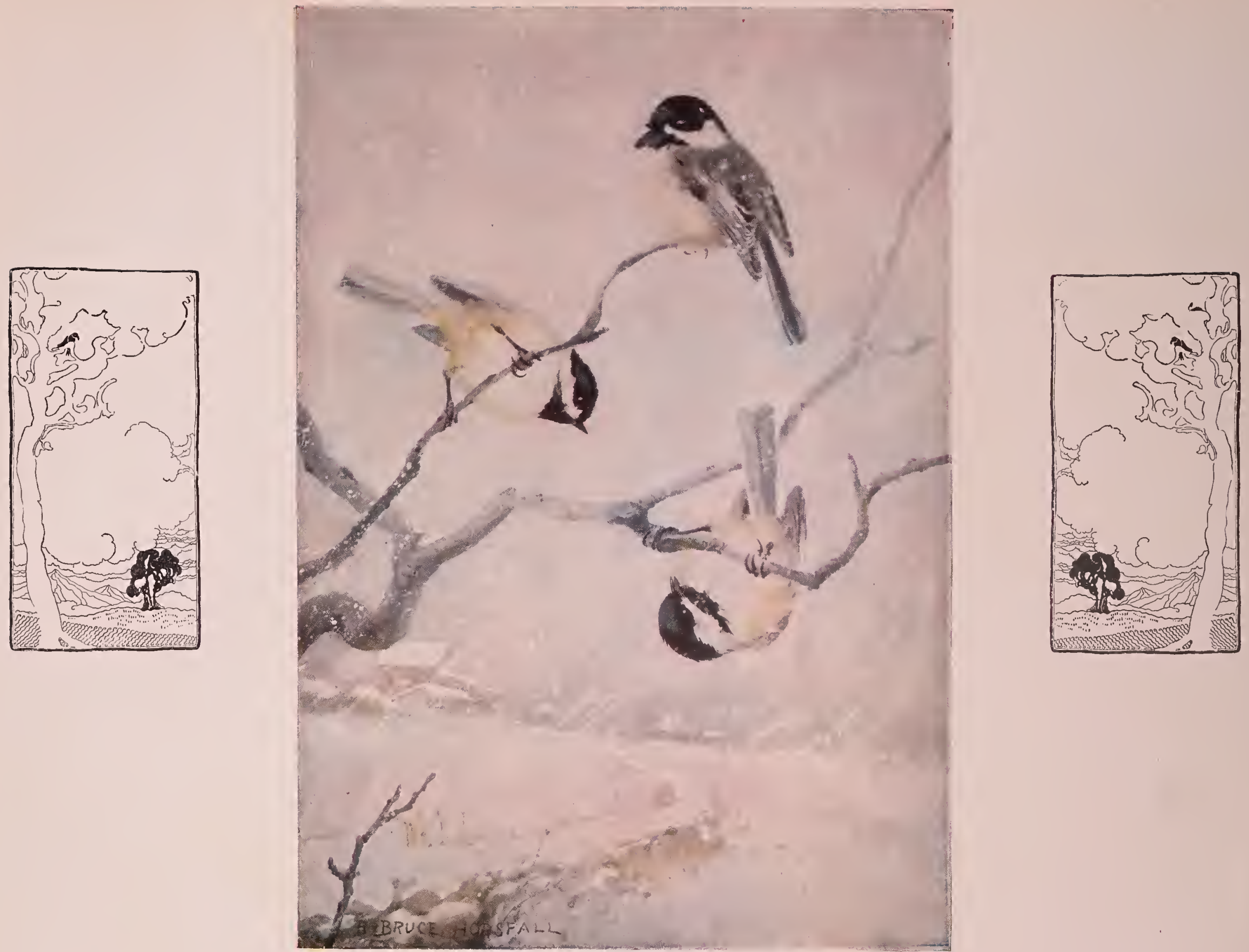

\section{CHICKADEE}

"The ground was all white with snow one day Janice and Bobby were busy at play. I was "singing near by in a Christmas tree, Making my song out of 'Chic-a-dee-dee.'

"I had not been chirping that way very long, When Janice heard me so loud with my song. 'Oh, Bobby, come to the window and see The sweet little bird chirping "Chic-a-dee-dee.",

"I think that I would be much out of place If I tried to enter 'Baba's bird foot race.' My feet are so small and toes they turn in. So there's no reason at all that I could hope to win." 


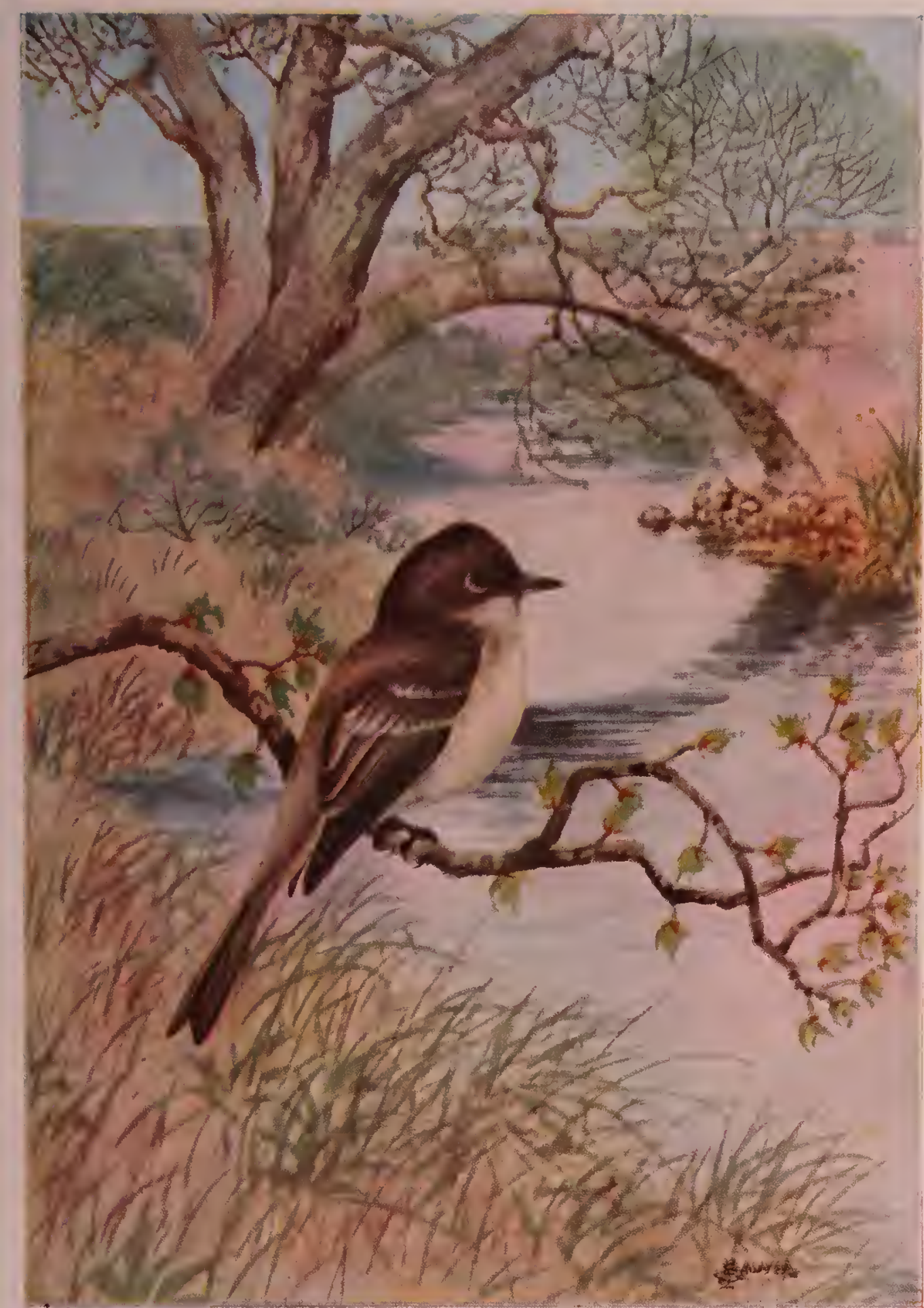

THE PHOEBE

"I would like to go to the foot race And be with the rest, But how can I do so and Leave my dear nest?

"Papa says he must go.

I will help get him a place.

As they will surely want a Phobe In the birds' foot race.

"If he don't win a prize I know he can sing, We will continue to live And make the woods ring."
TOWHEE

"I'll try to do my part

In the grandstand,

Have been chosen by Eagle To sing in the band.

"Music does not worry us If the race depends on that, As we all have good music Right under our hat."

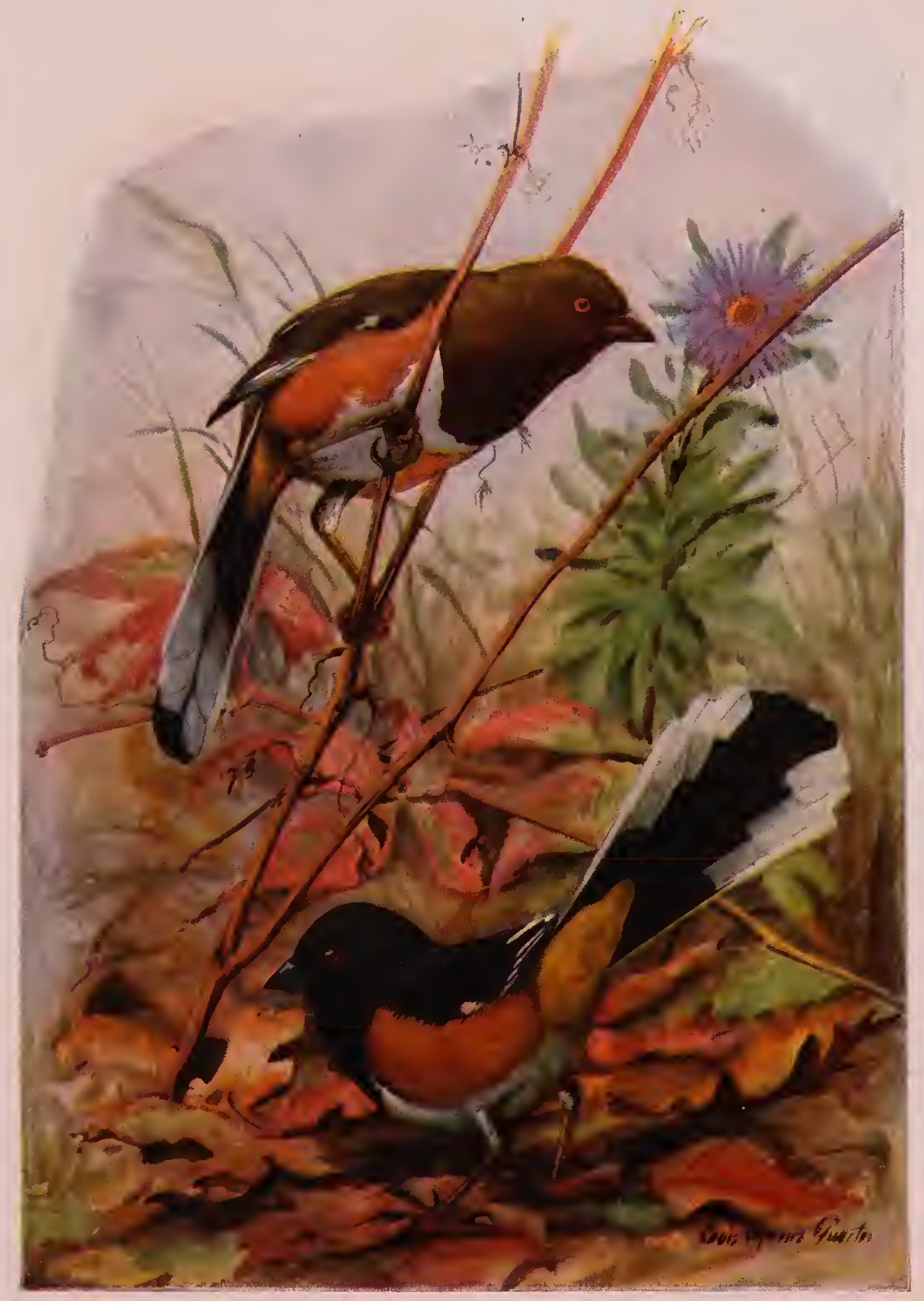



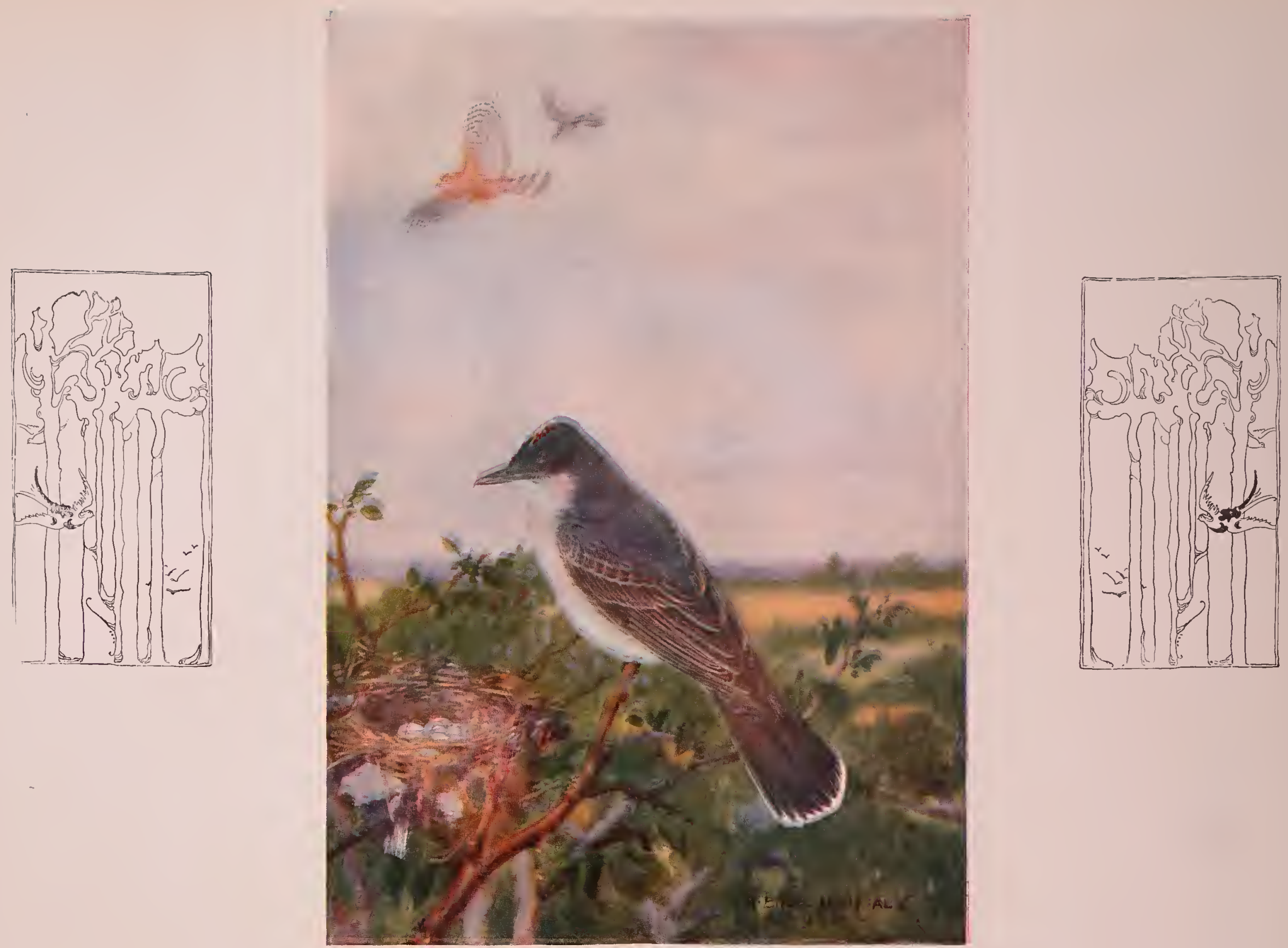

\section{THE KING 'O THEM ALL}

"I'm the King of Birds, so they all declare, I fight on the ground and I fight in the air. Am never contented from morn until night Unless I am the winner of a big bird fight.

"I will enter myself in the birds' foot race.

There'll be no question but I'll hold my place.

I have the entrance fee to pay my toll,

Am going to try to get next to the pole.

"If they have any trouble keeping the birds in line, I will help the Police Bird and be there on time.

There is one thing about that race I can't see:

Why they did not give that police job to me.

"They said they were sure I could handle it right. But they were afraid I'd do nothing but fight. That's an awful career for a bird, all right, But I'll end up my days and continue to fight." 

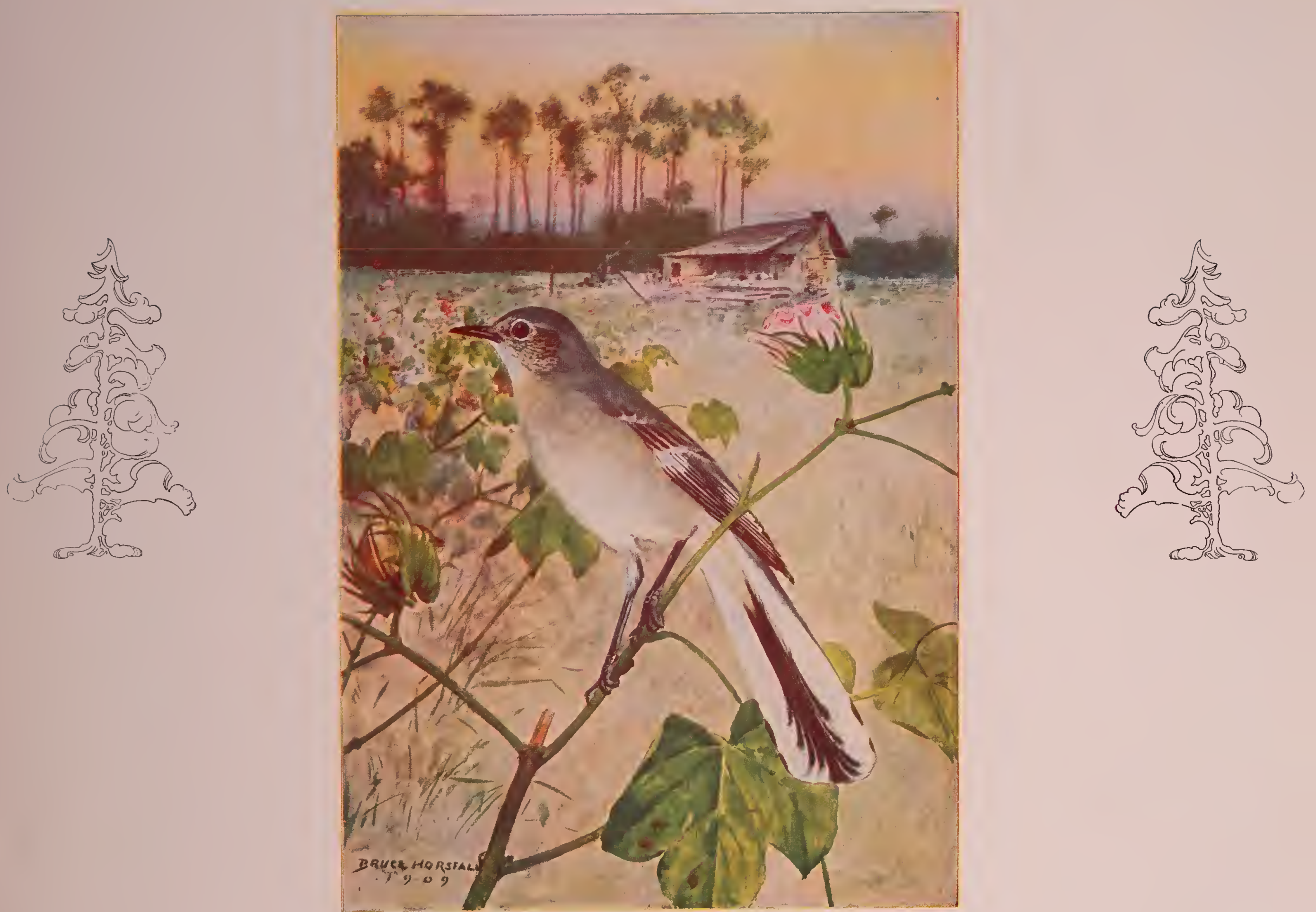

\section{THE MOCKINGBIRD}

"I'm the world's famous singer, the gay Mockingbird: And can mock any song I ever have heard. I sing in the mornings and whistle at night, And to make the world happy is my chief delight.

"I'll wake in the morning and go to the race: But as mocking that day will be out of place, I'll have to quit mocking, and get down and run, And then I am sure I'll miss none of the fun." 


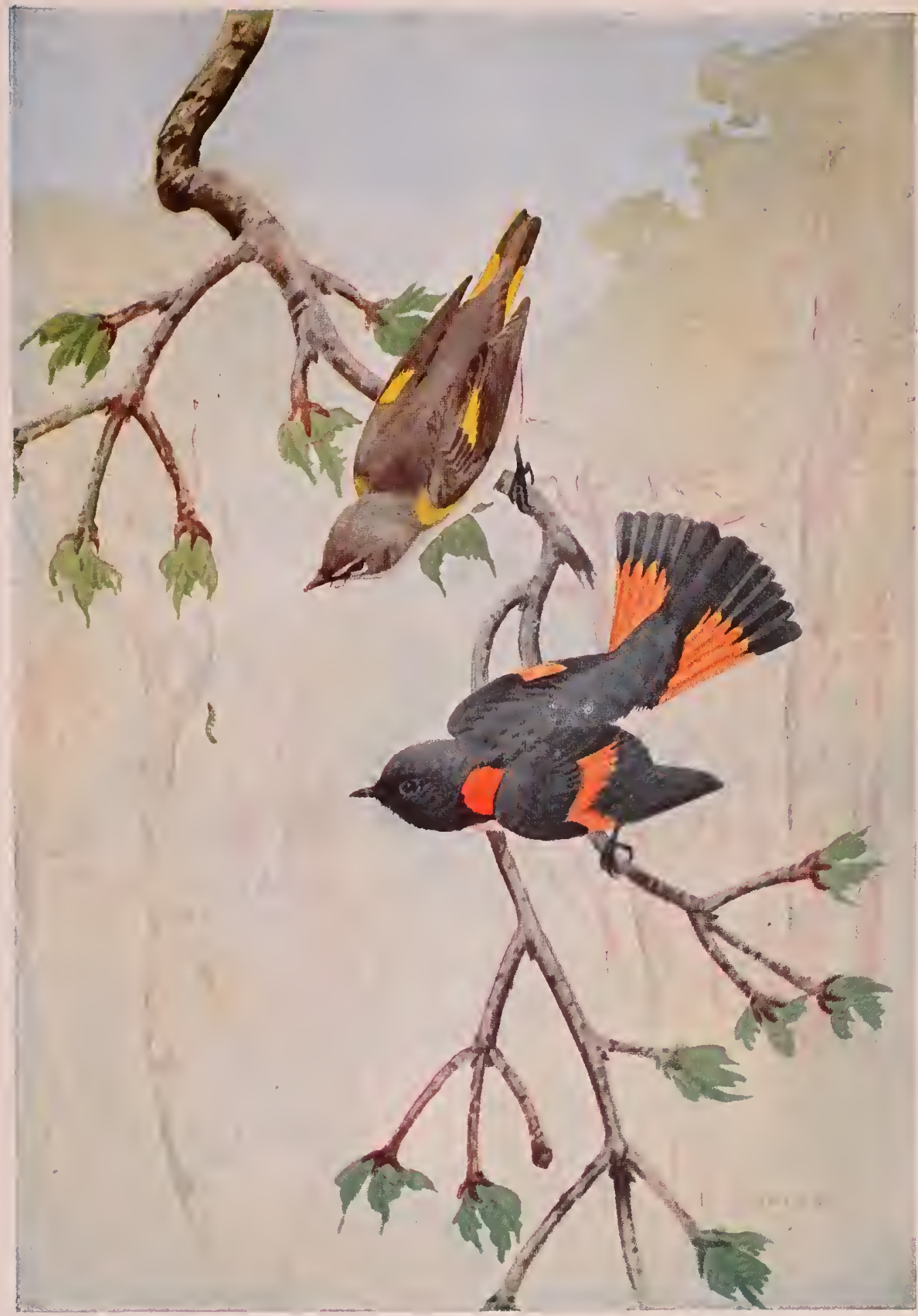

\section{THE VEERY}

"Believe I could run

If I could get a good place, Would like to have the honor Of winning that foot race.

"The prize is worth having, Is my only good thought, For a nice bed of worms That are all ready caught."

\section{REDSTART}

"I'm shy of those foot races, And will tell you why, As the birds all tell me We dare not fly.

"I am going to go, and sit close by, Will not enter if I cannot fly.

I love to fly, and love to sing,

A race on the ground is another thing."

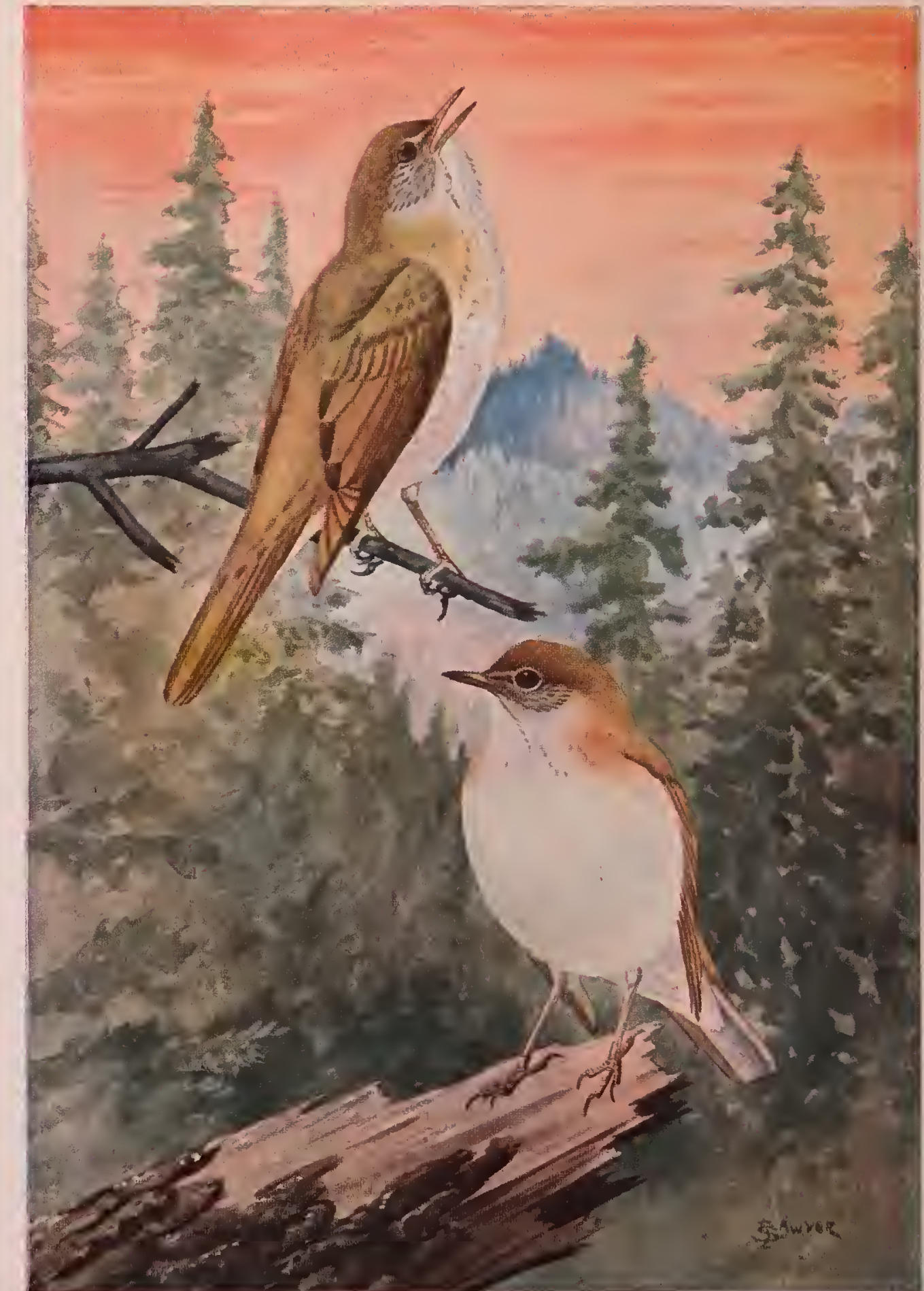



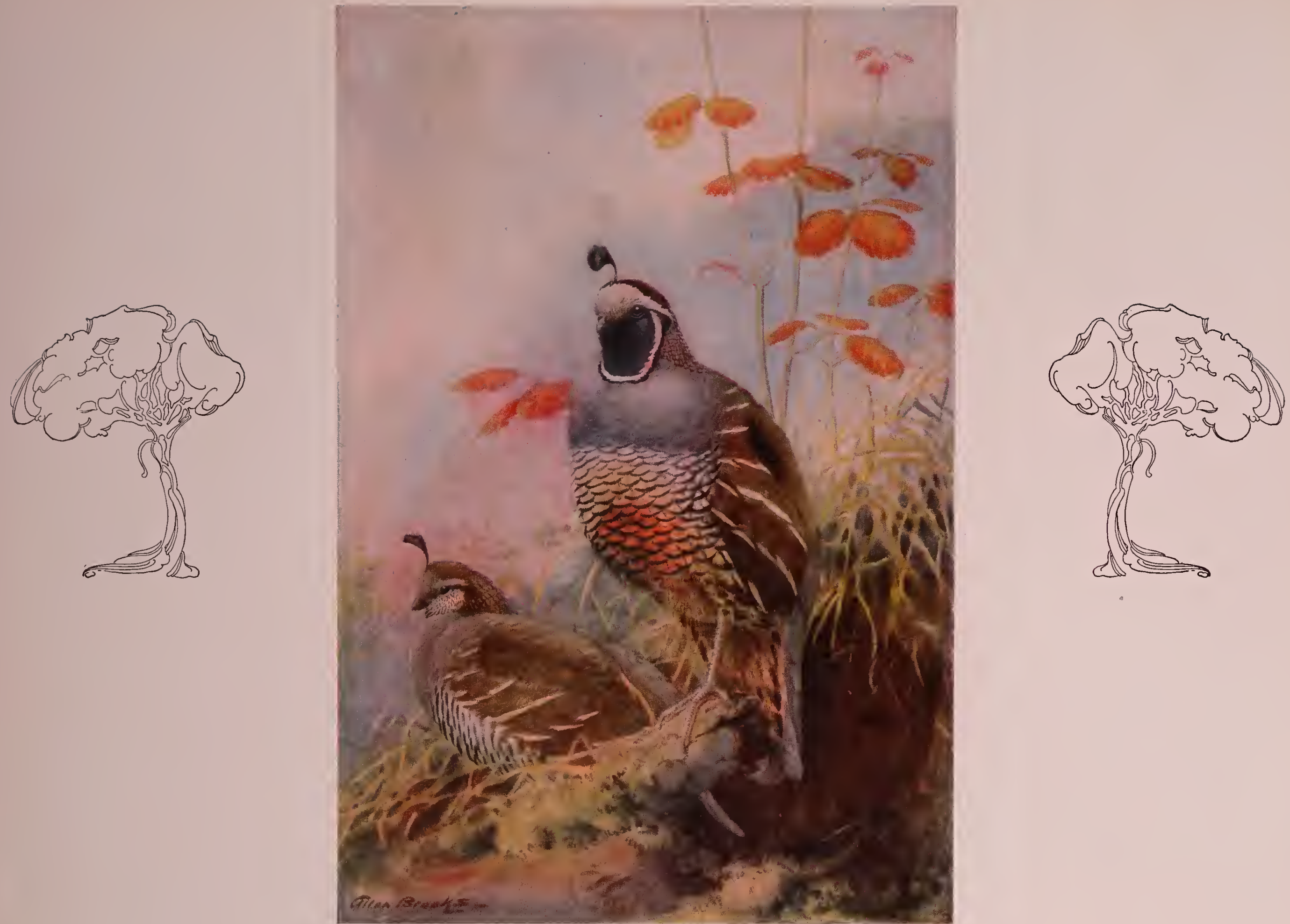

THE PARTRIDGE

"I know I'm a Partridge.

Some say I'm a Grouse.

Don't care what they call me.

Just stay away from my house.

"I've heard much about races,

And do want to go,

To show them my speed

That none of them know.

"Am sure I will win

If everything's right;

I'm afraid of no one

Except Sir Bob White." 

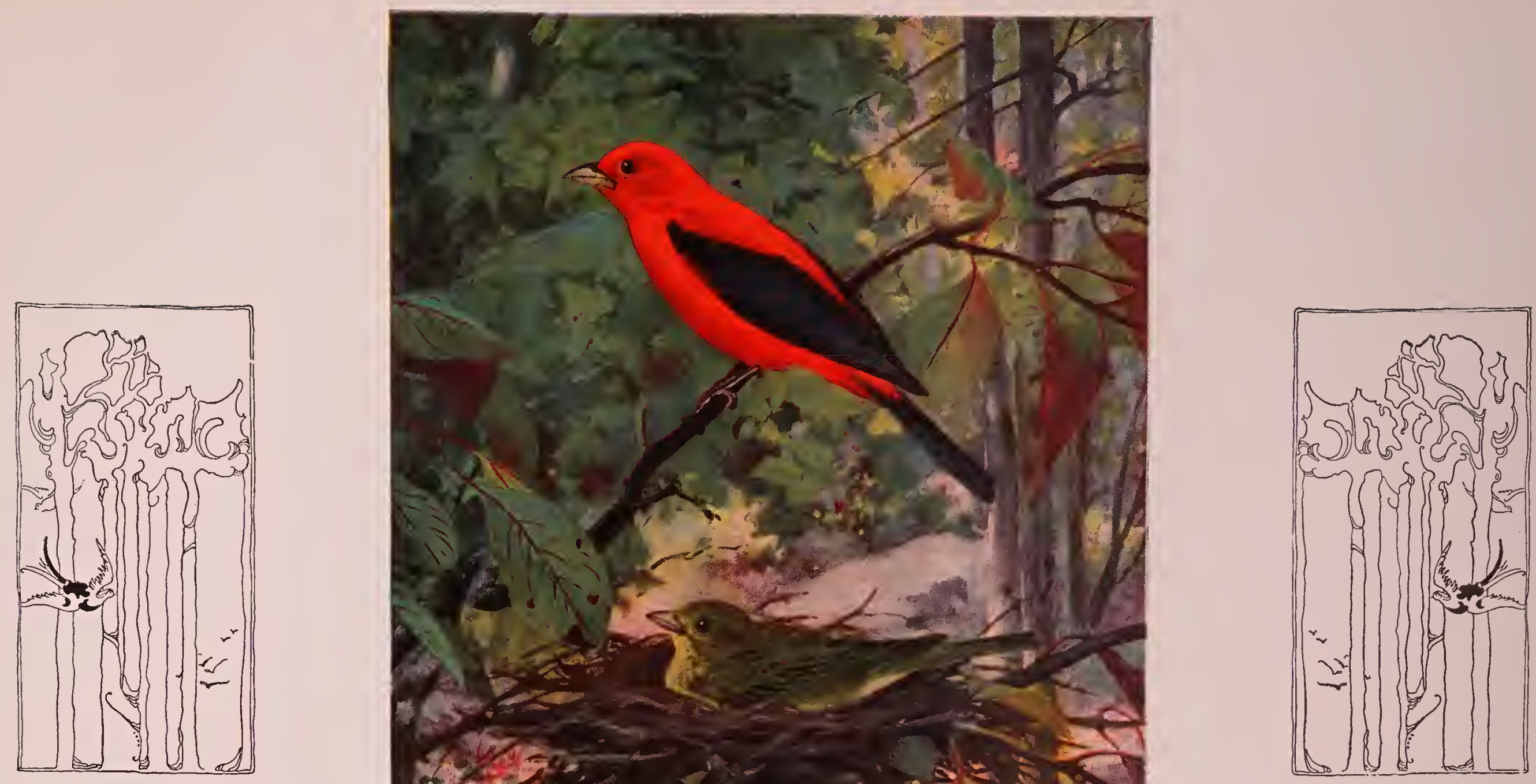

\section{SCARLET TANAGER}

"Just received information, that came at the last, That all the race news would be surely broadcast On all the radios from far and from near, So that absent birds can all plainly hear.

"From all the news that I've heard of late, The great birds' foot race will be up to date, The Eagle and Thrush are working it so The race will be broadcast by quick radio.

"To the Eagle and Brown Thrasher I am not much relation, But would like to have charge Of the broadcasting station." 


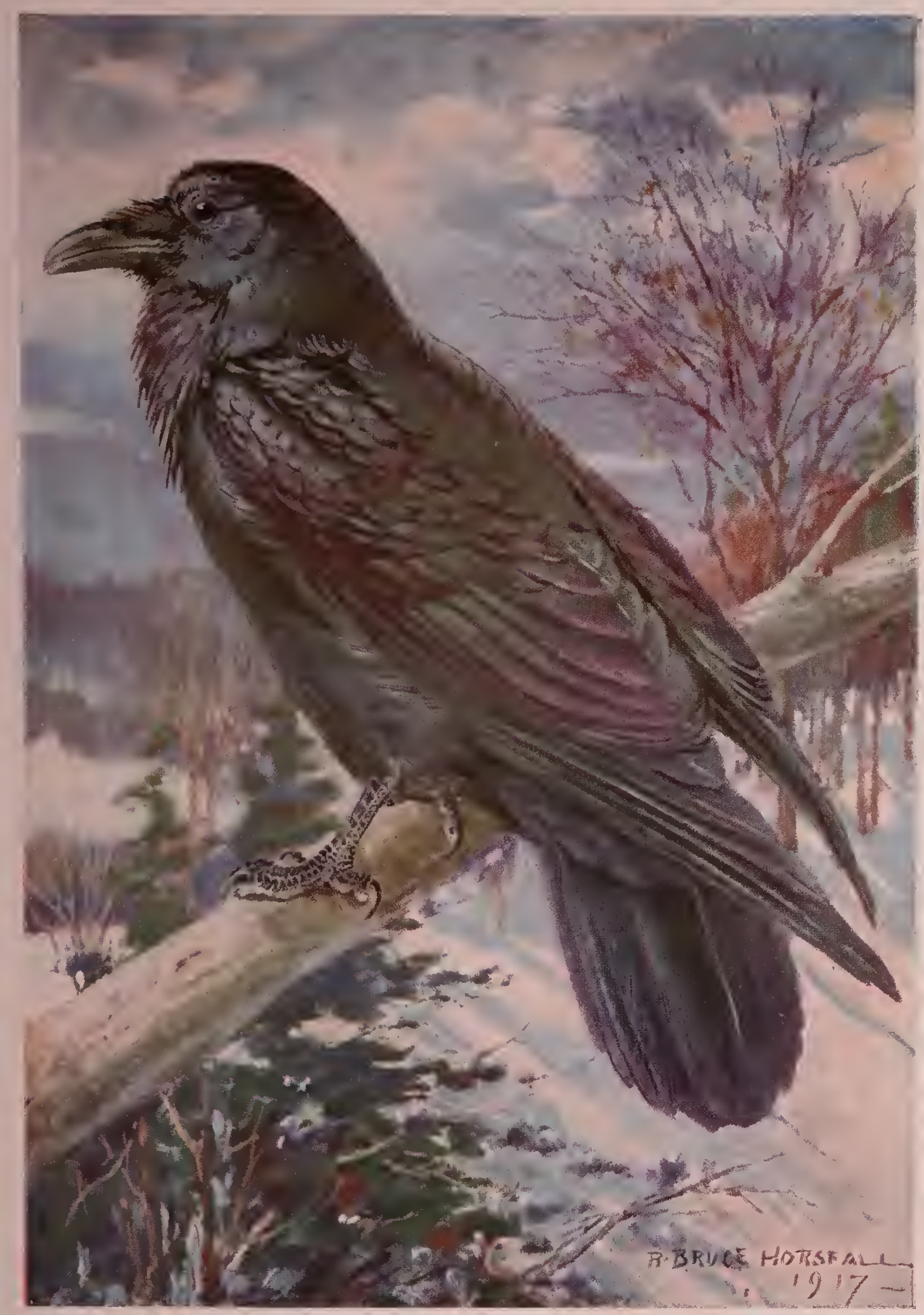

RAVEN

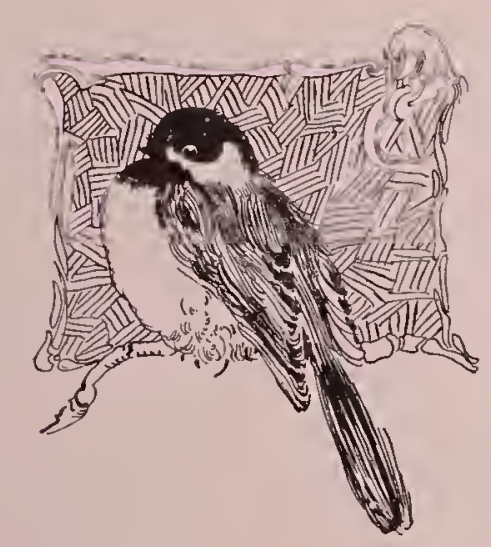

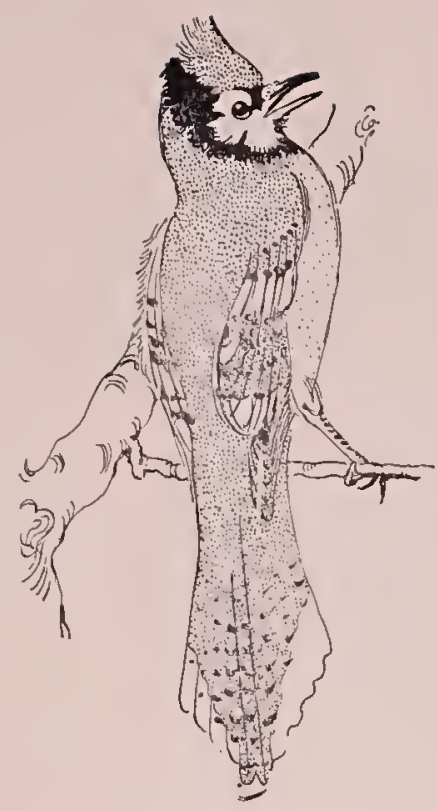

\section{THE WISE OLD RAVEN}

"The wise old Raven,

Very popular you know, That's why good people Rave over me so.

"You have all heard the fable: If you would stop to think When I dropped in the pebbles To get me a drink.

"In my lifetime I have been In a great many places. But never did they have Any birds' foot races.

"I am going out to Bird Town some day, To see what other birds have to say. If birds of the town are talking race I will enter in time to get a good place." 

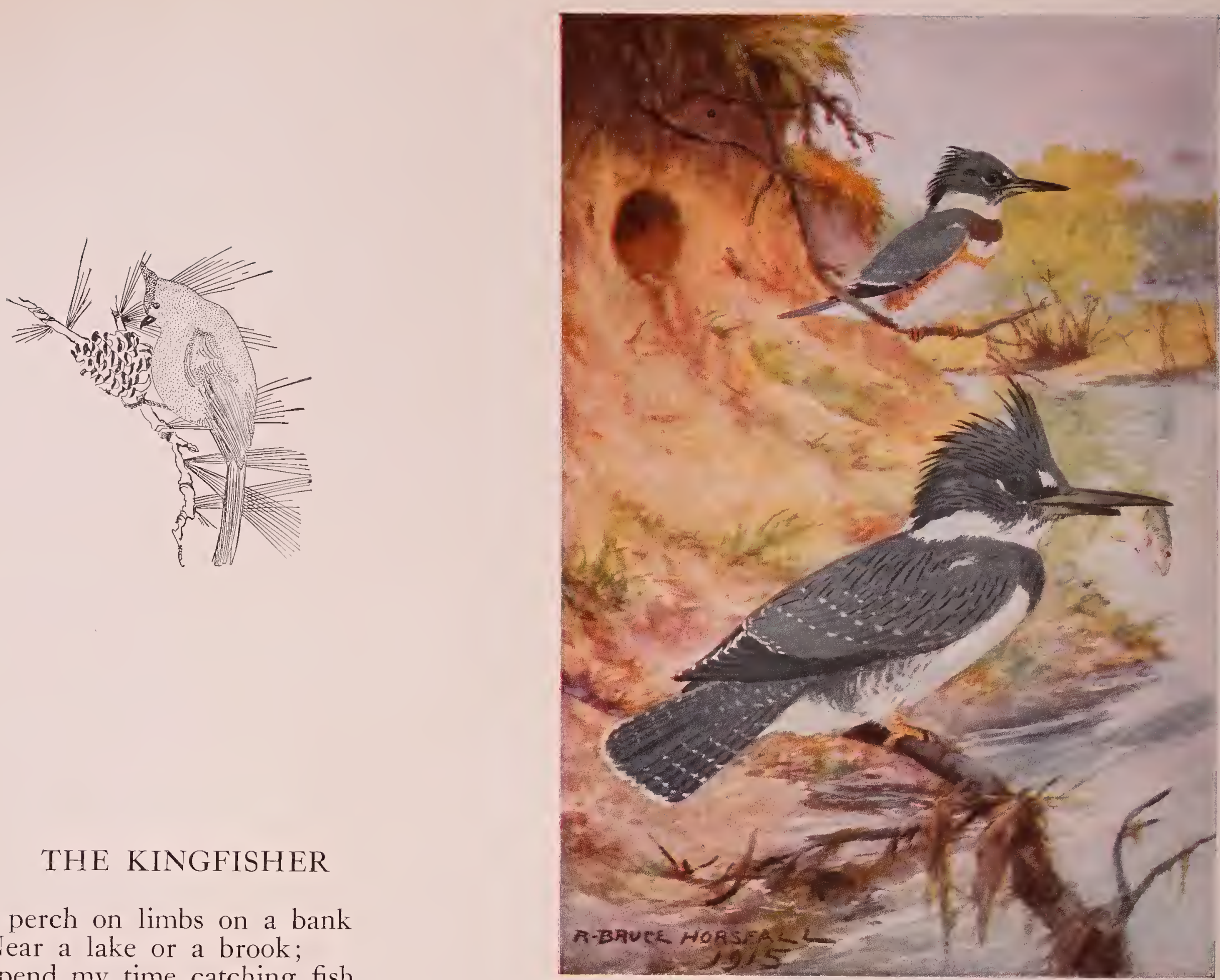

\section{THE KINGFISHER}

"I perch on limbs on a bank Near a lake or a brook; Spend my time catching fish Without the use of a hook.

THE KINGFISHER

"I love to catch fish

But I have to keep still, Then I dive into the water Bring them out with my bill.

"I am going to the races,

To see the birds on the throne, But I cannot leave my babies As they will not stay alone.

"I will give them my promise, And leave them my best wish That when I return

I'll catch them some fish."

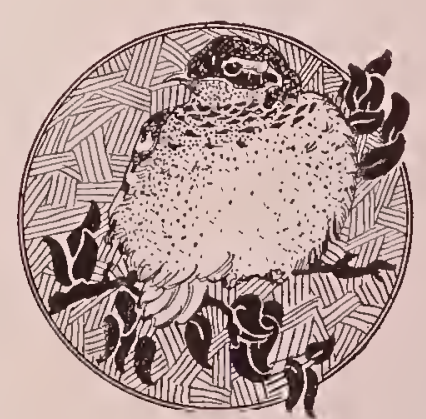




\section{THE KINGLET}

"Our native color is orange and black

We hunt for our living on sunny banks.

Sometimes there are brooks below,

But that makes no difference

With our hunting, you know.

"A few weak chips, chirps, and trills Echo from the near-by hills;

We may move from this pretty place If we should win the prize

At the birds' foot race."
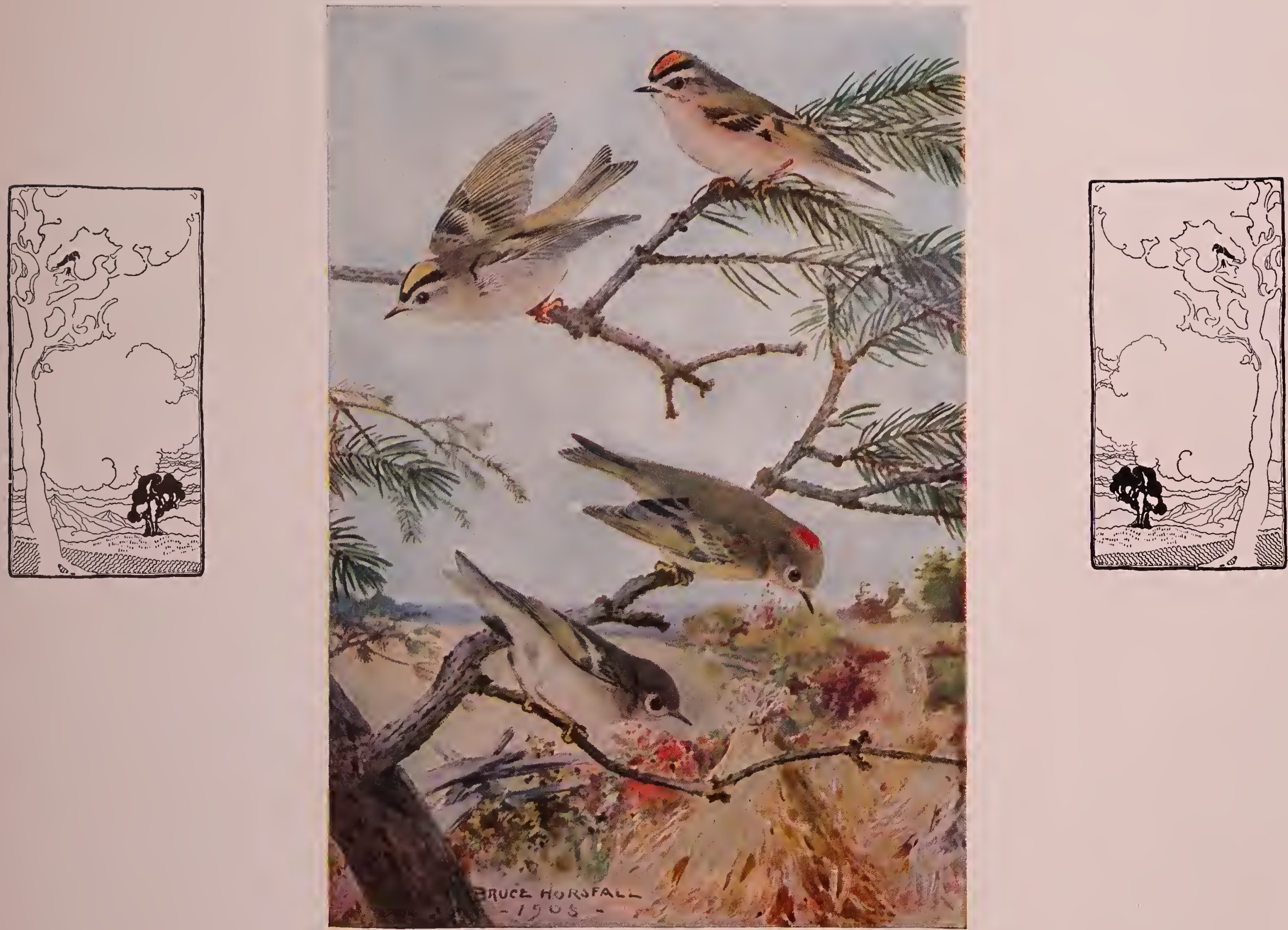

THE KINGLET 


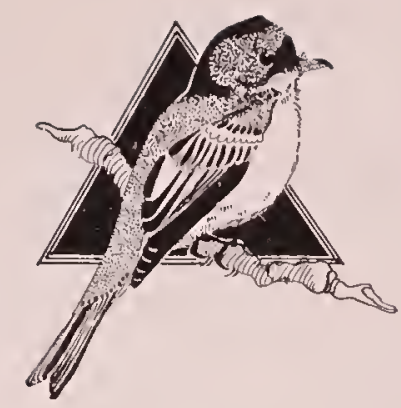

THE ORIOLE MAKES ENGAGEMENT WITH THE FLICKER

THE ORIOLE

"Cuk, Cuk, Cuk, Quit-U, Quit-U,

That's a pretty home you have up there.

But with mine it don't compare,

Yours is only a hole in a tree

Mine is up high so no one can see.

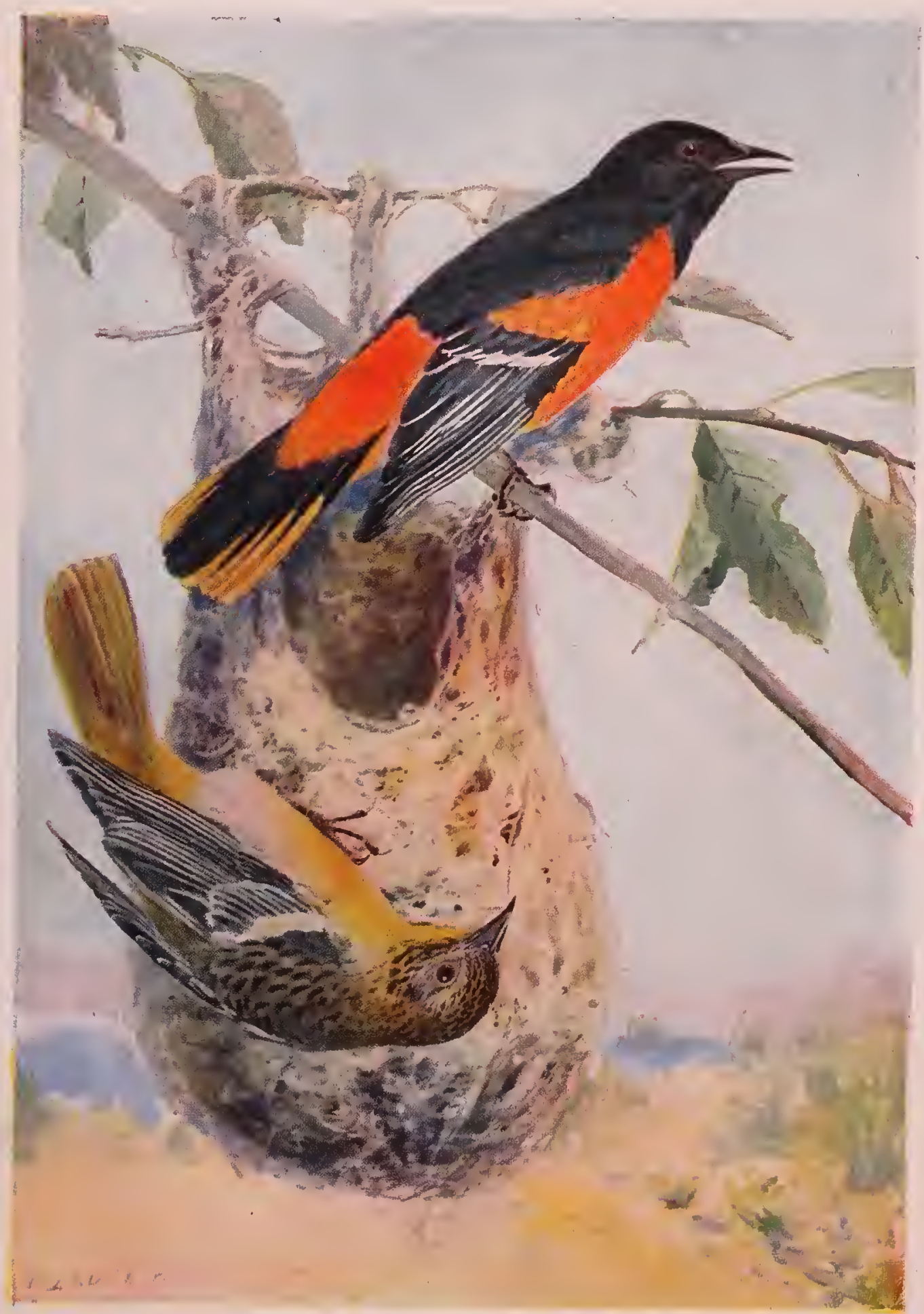

BALTIMORE ORIOLE

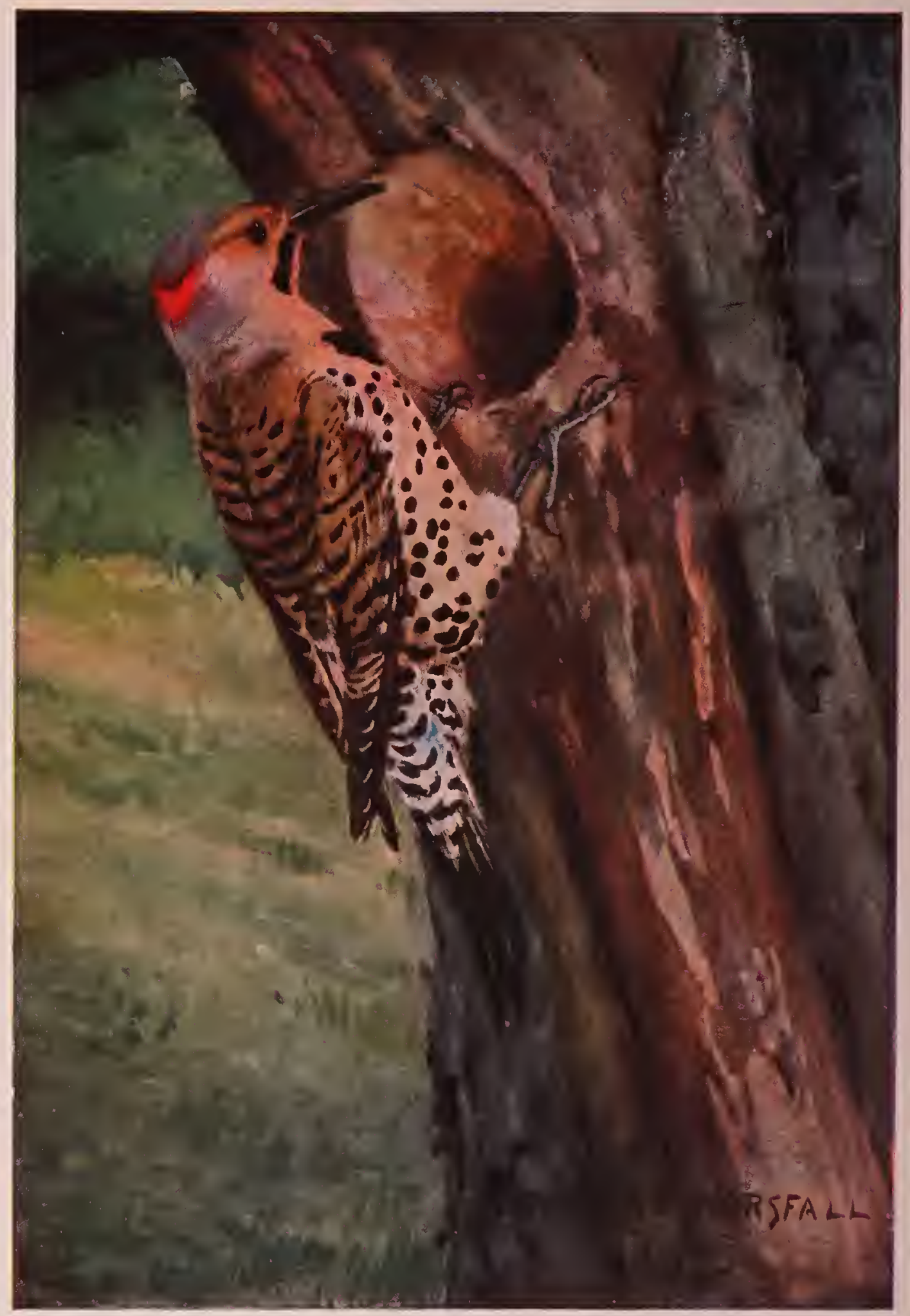

FLICKER

"If you will go with me to the birds' foot race, I'll take you to my pretty place.

I hate to go there all alone,

When I am so far away from home."

THE FLICKER

"There will be scores and scores

Of pretty birds there.

But with you and me

They will not compare.

"I expect some of them will be very slow,

That is one reason you should go.

The races you will love to see.

Be sure you do not disappoint me." 


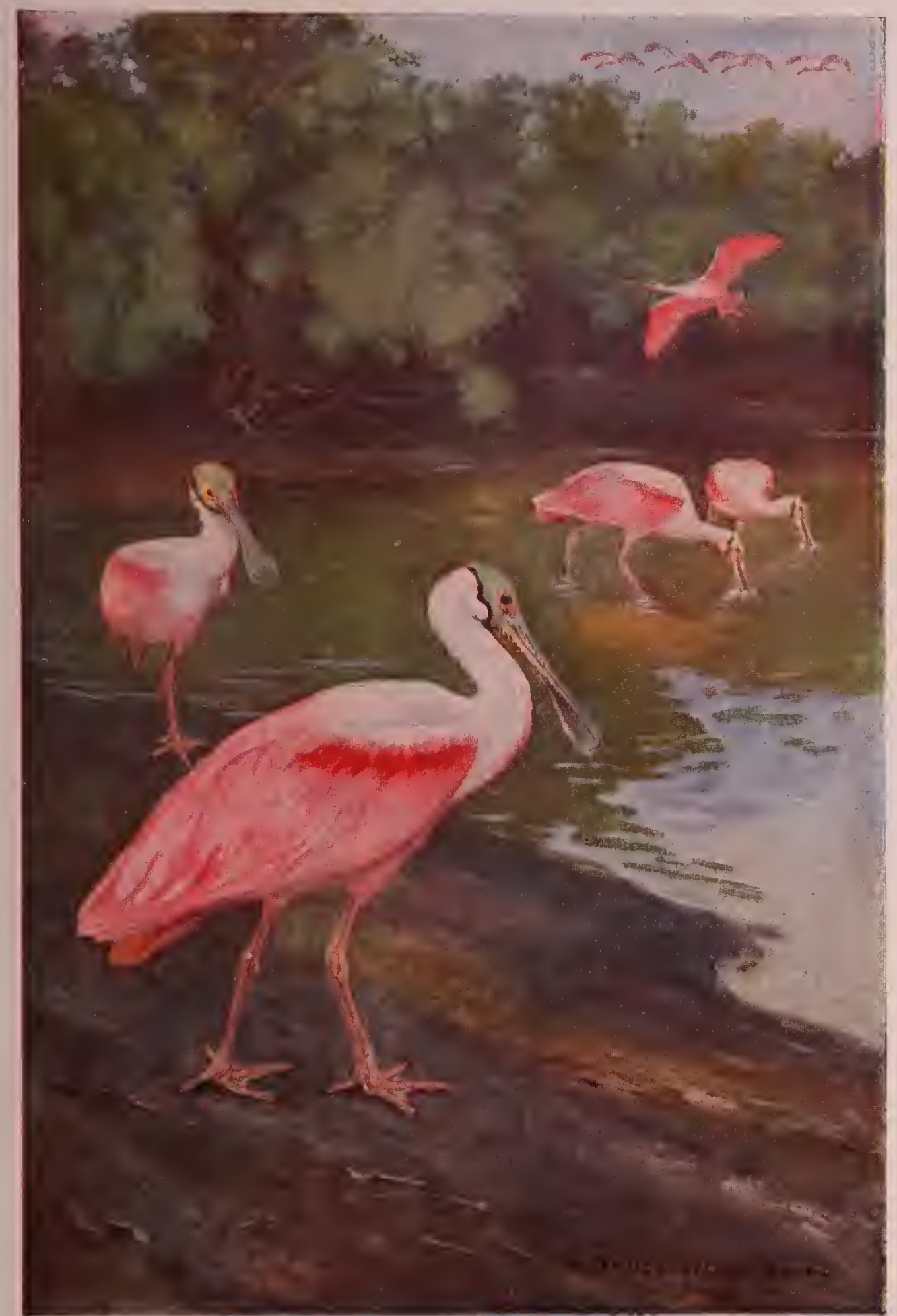

ROSEATE SPOONBILI

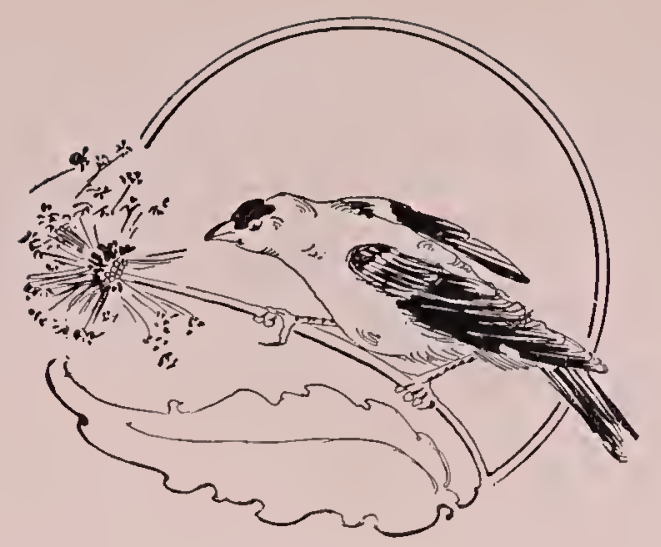

\section{ROSEATE SPOONBILL}

"Am much interested in the races, Although I am very slow, They have chosen King Parrot For the bird to say 'Go!'

"I talk in my own language, But few birds understand, For in my own country Am the pride of the land.

"When I first heard of the race, Thought I would have a good run, But after thinking it over, May go just for the fun.

"Would much like to be present, If I can get there on time, The long distance I travel Is no fault of mine."

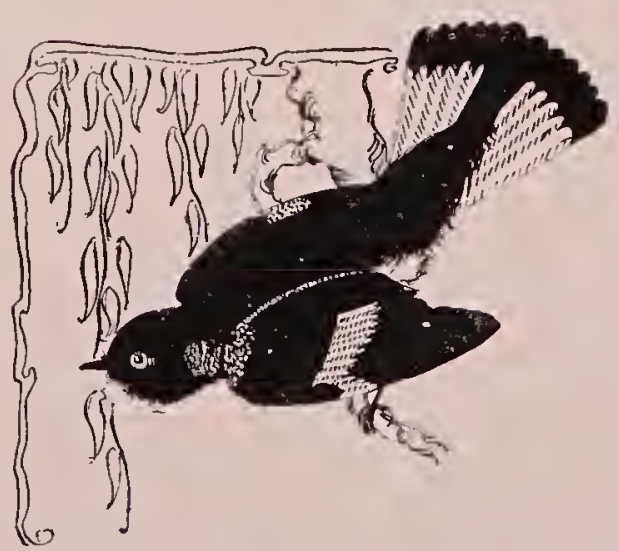



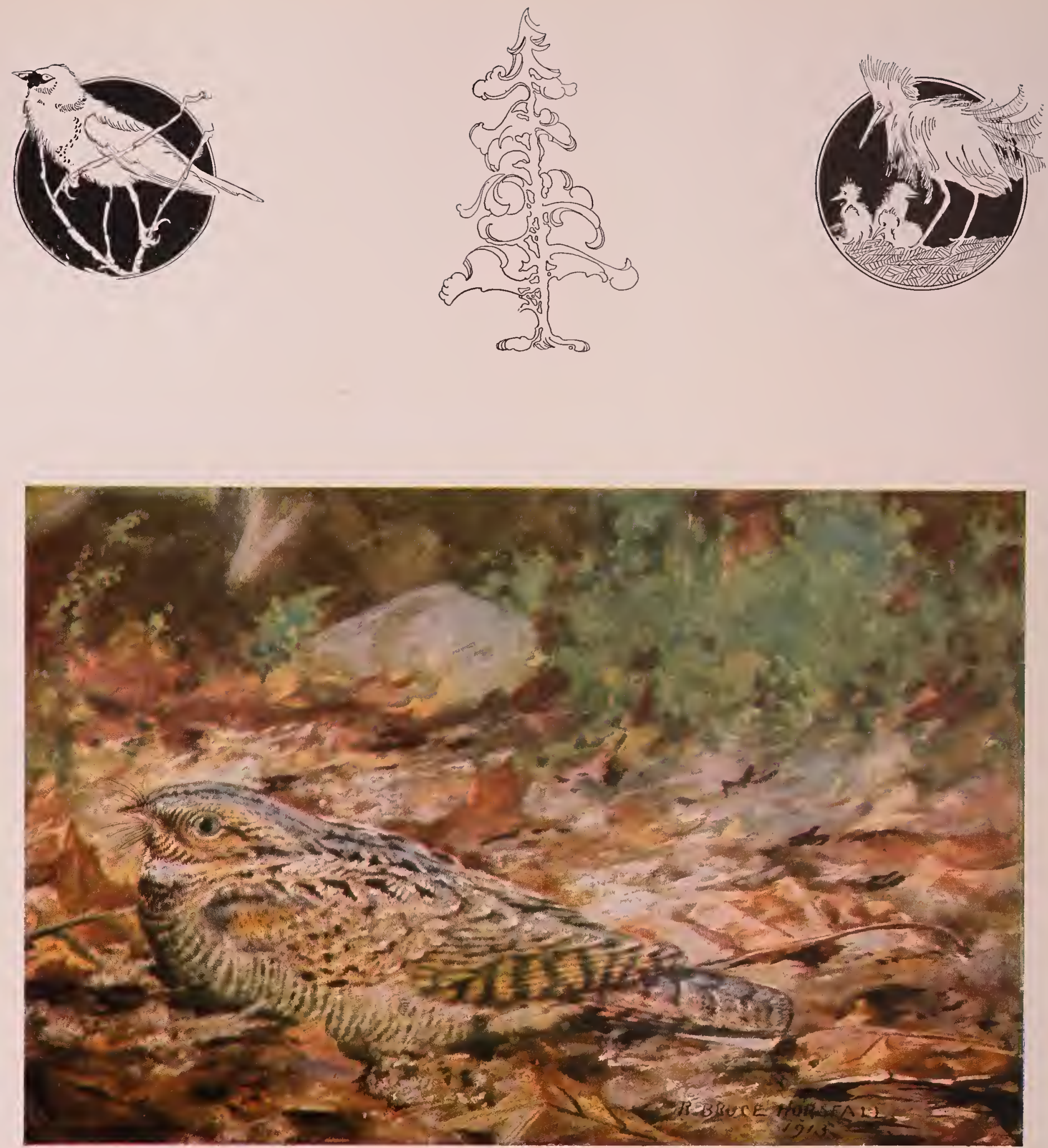

THE WHIP-POOR-WILL

"I'm the well-known Whip-Poor-Will And all I eat goes through my bill.

"I don't eat much for all of that;

So it's very hard for me to get fat.
"I notice the old Owl has mentioned me, As I am about the only bird he gets to see.

"I often stay out late at night.

And that's the time he makes his flight.

"We'll all meet at the birds' foot race,

The Owl will be there with his pretty face." 

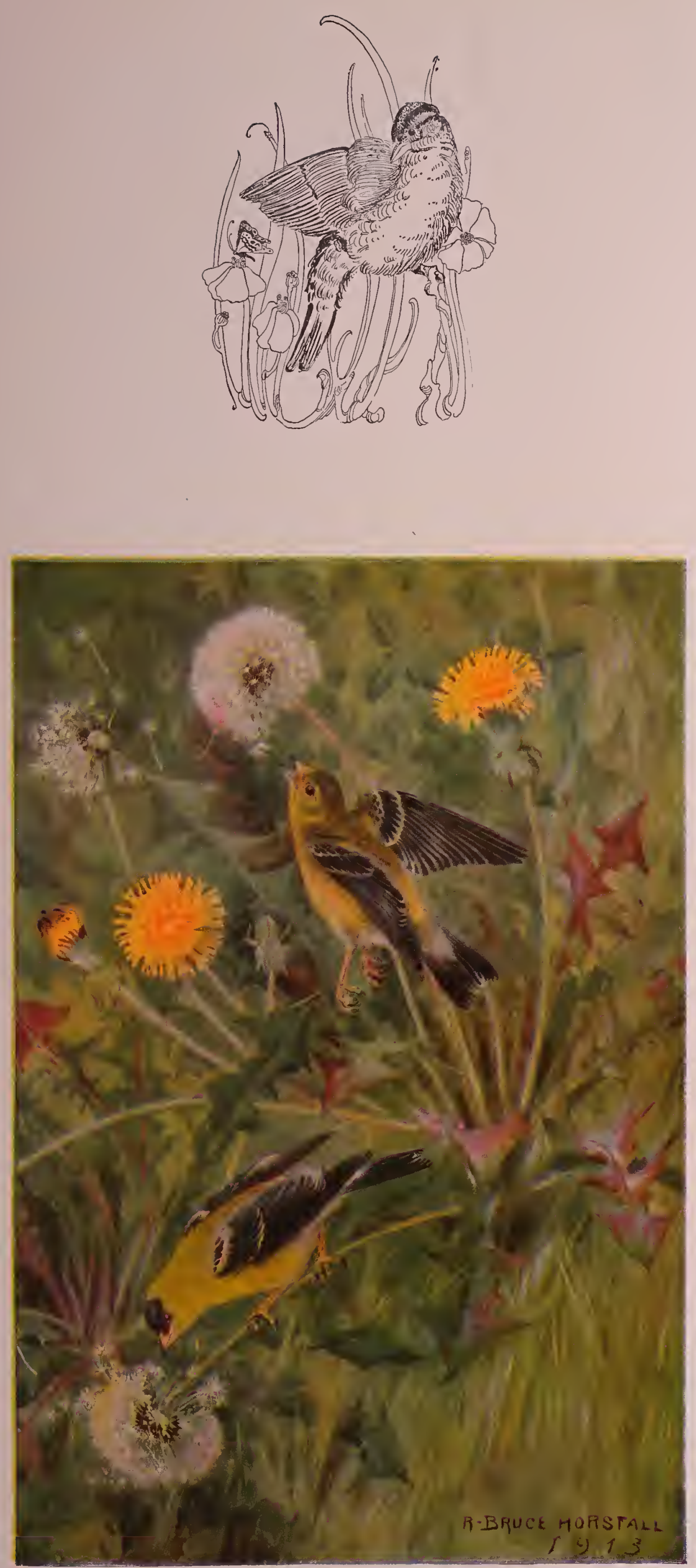

GOLDFINCH

\section{GOLDFINCH}

"The whole world is my admirer, With my make up de luxe, Clear back to the days Of our Old King Tut.

"Just had a talk with the Eagle, And the Brown Thrasher, too, They told me of the races They were going to put through.

"They were very much excited, And had only a little time But said that most all the birds Would surely fall in line.

"With all my style and fashion I am right in the lead. Up to date in all ways. But never tested for speed.

"They said the Quail and Partridge Were both good on the run, Also the Crow, Robin, and Jay, Said it would be lots of fun.

"I am going to watch them To see who will beat, And I want to go early To get a good seat." 

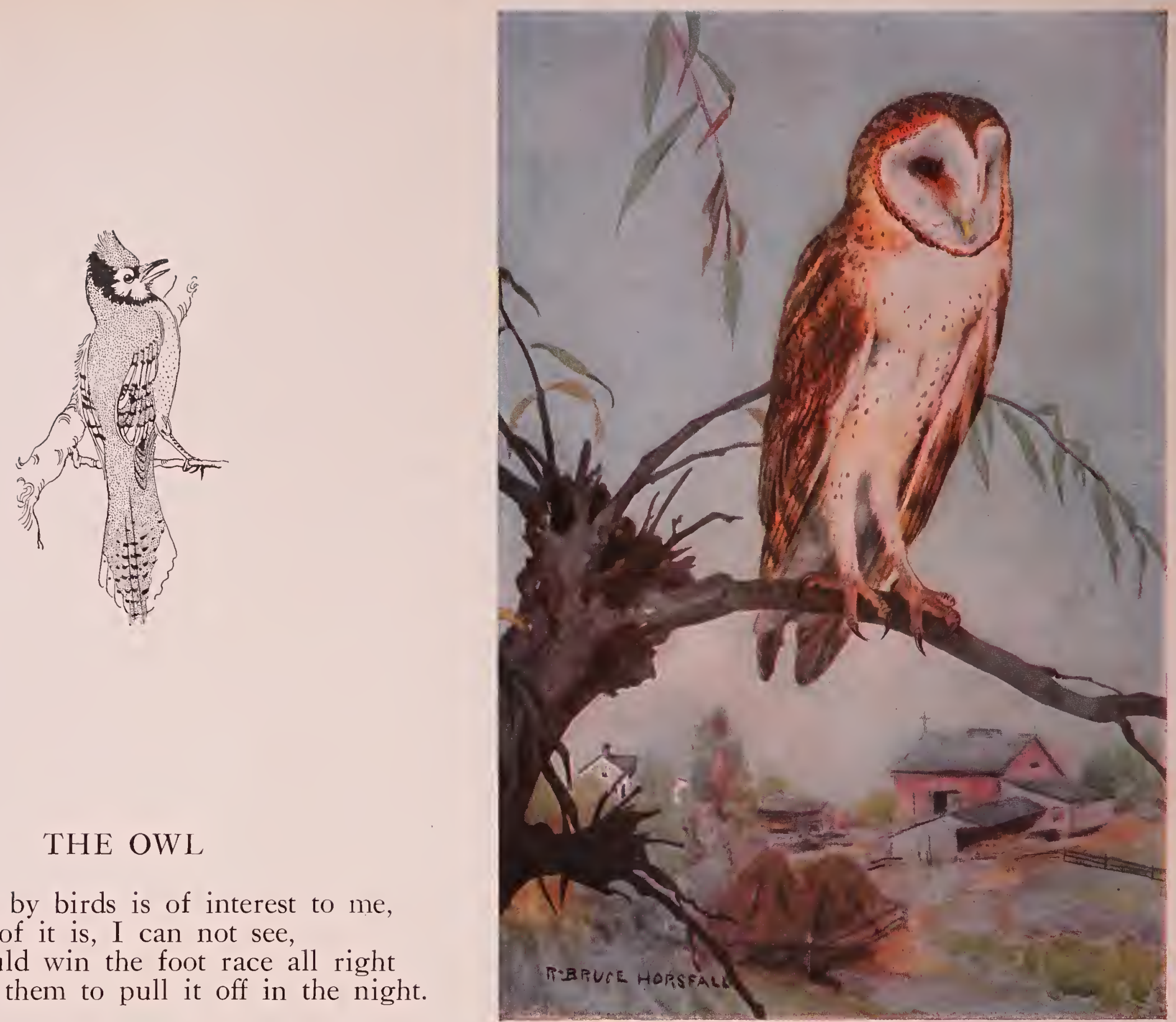

"That foot race by birds is of interest to me, But the worst of it is, I can not see,

Am sure I could win the foot race all right If I could get them to pull it off in the night.

"Whoo Hoo, Hoo. Wouldn't that be fun; For me to watch the other birds run? They all would have to carry a light As none of them can see his way in the night.

"The Nighthawk claims that he can see, But that claim of his never bothers me, The proof of the pudding is chewing the string, For me to see at night is one sure thing.

"The Whip-Poor-Will stays out late, As catching night flies is his fate; He flies up high and loops the loop; But for me I'll take the chicken coop."

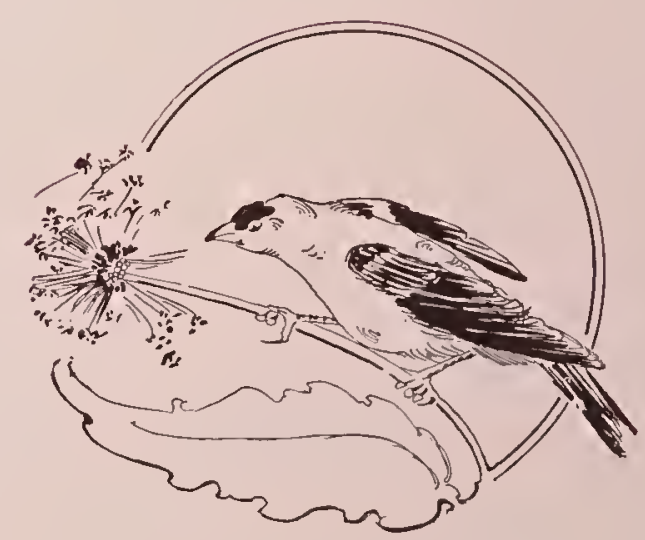



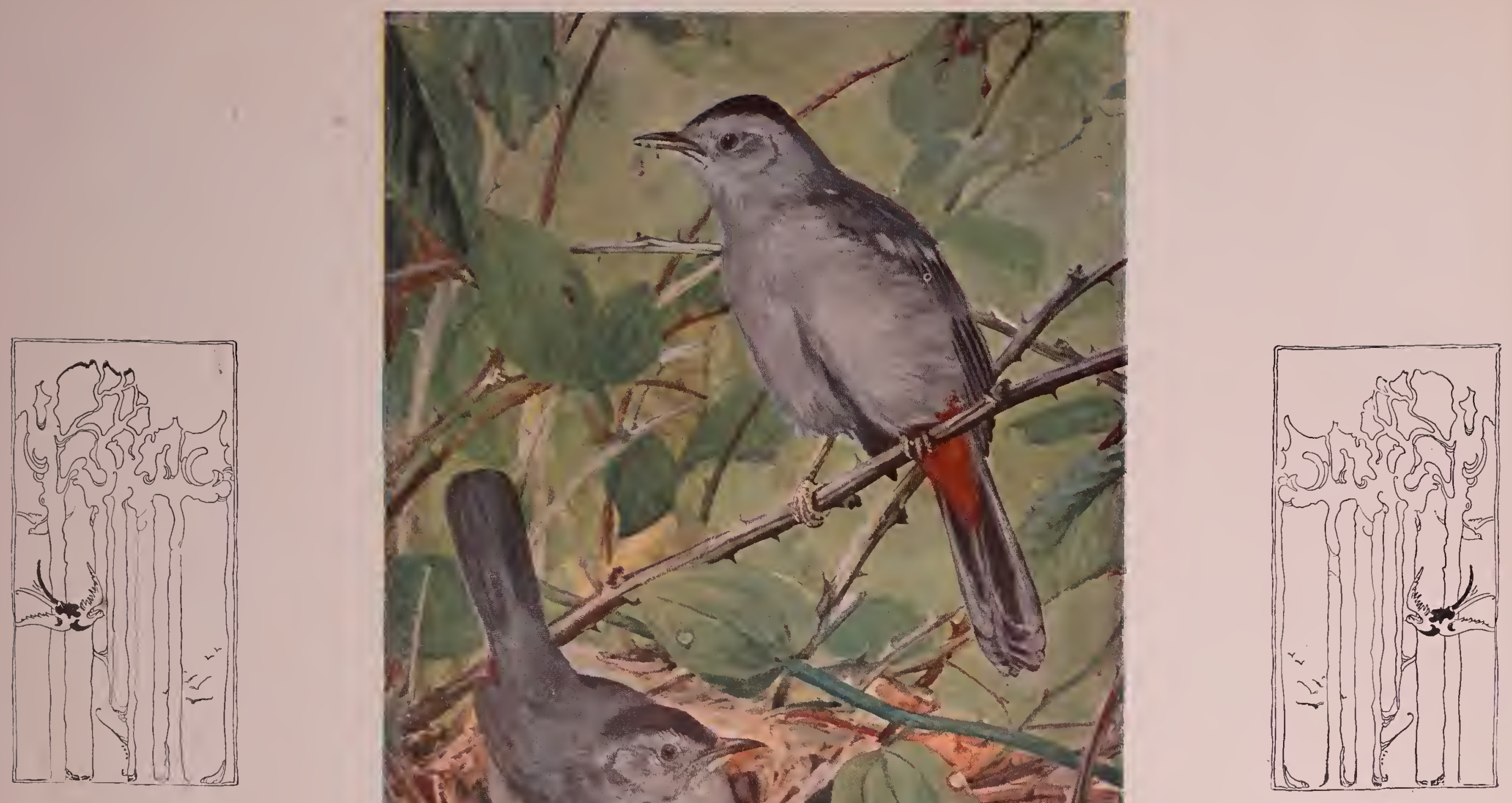

\section{CATBIRD}

"I love all the surroundings

Of which our country is made, Even the twigs in my nest And my four greenish-blue eggs.

"My song is a medley, And quite sweet at that, I can mimic most anything, Even the call of a cat.
"I am going to the races, After all's said and done, As I have a real bird hunch That I am good on the run.

"If I should come out the winner, Get my name on the prize, Wouldn't that be a record And make birds open their eyes?" 

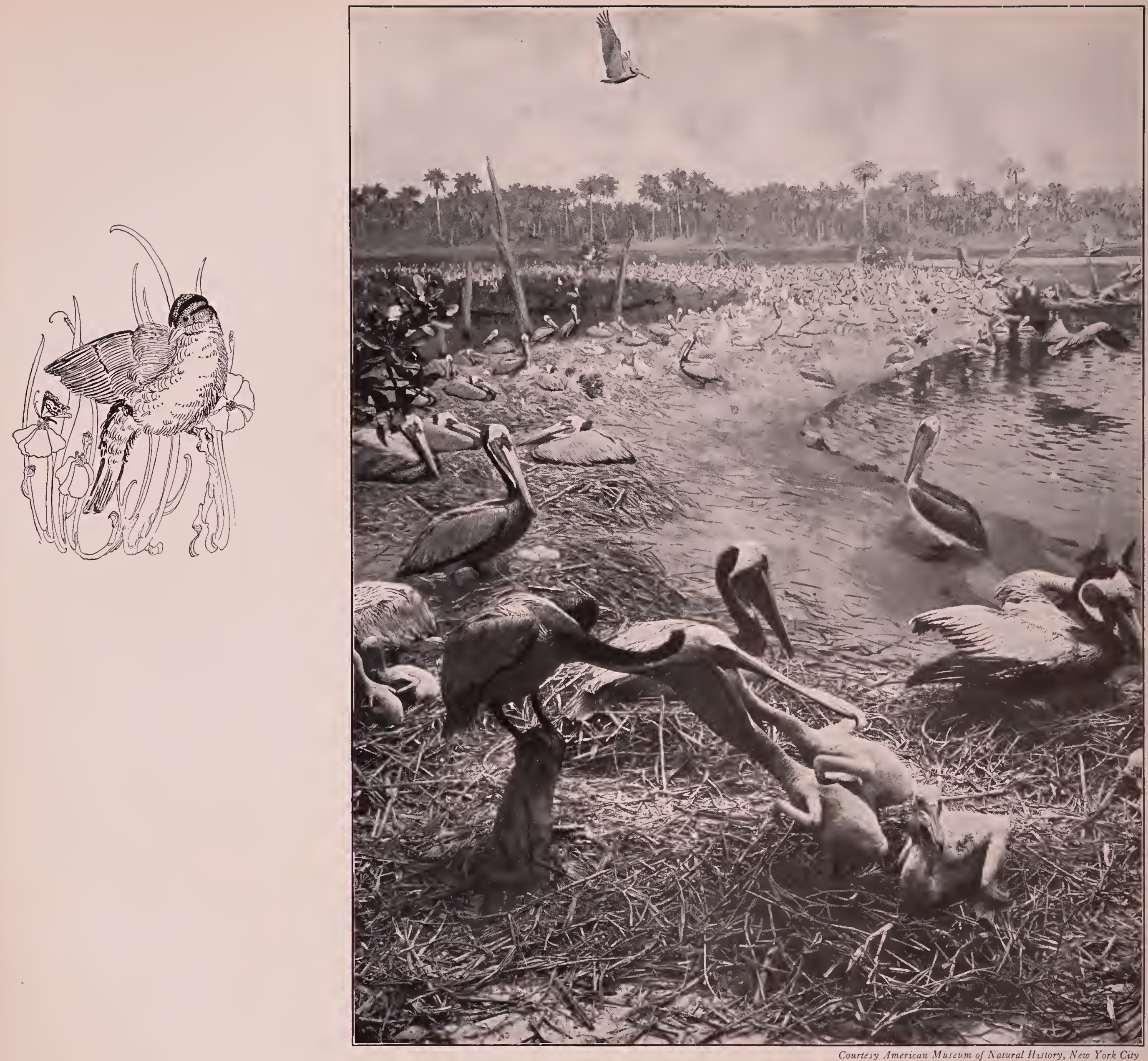

\section{MRS. PELICAN}

MRS PELICAN

"At the race I'll be known as Mrs. Pelican;

My bill holds more than my stomach can,

I hold enough in my beak to last me a week,

Other birds don't see how I ever can.

"I'm not like the old lady Hubbard;

I always have plenty of food in my cupboard,

For my babies that wait on the shore,

They are contented to wait, though often late,

As they know I will bring them some more."

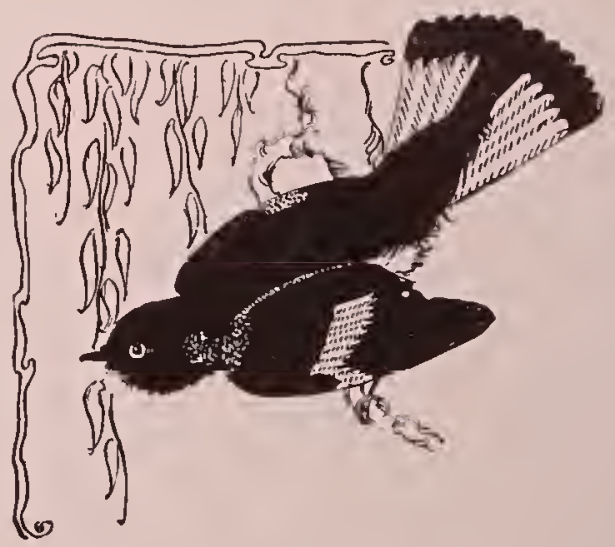



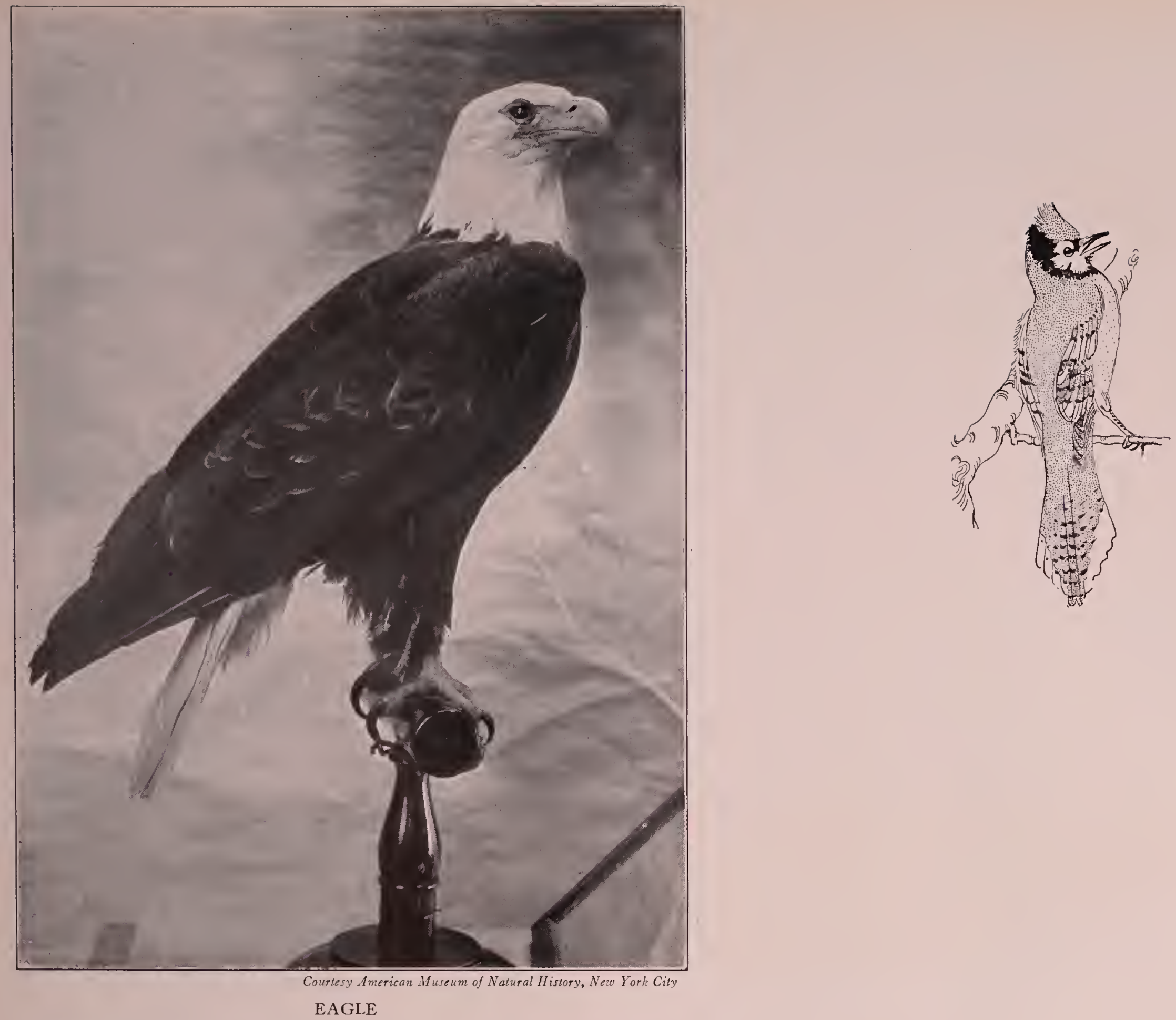

\section{THE EAGLE SAYS HE IS READY}

"The race track is ready, my work is all done, For the national race that's going to be run, We have had entries, not recorded in this book, As there are a few birds we have to overlook.

"There were some foreign birds that tried to get in, But we were a little afraid some of them might win, We will challenge all nations when this race is o'er, For the bird in the winning will want to run more.

"Making ready the race was a most encouraging part, As most all birds helped me right from the start, The Parrot was unmoveable and dreadfully slow, But he was the only bird that could really say 'Go'." 


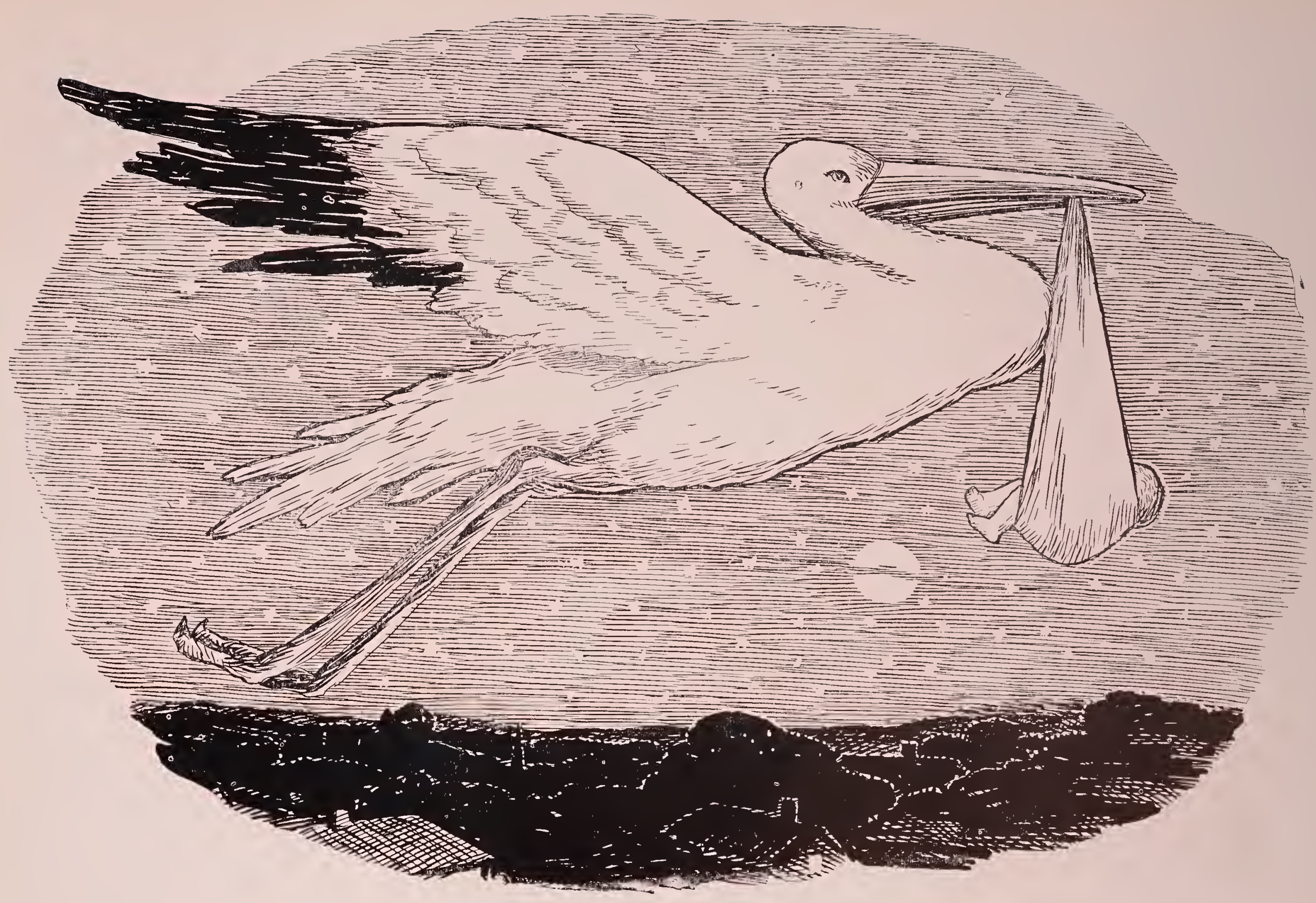

THE STORK AND ITS CARES

"Would much like to see

That foot race for birds

It will be most interesting to all

But under my assignment to babies

I am most subject to call.

"Birds all say I should be there

Not knowing I have other cares

I am so busy working night times

I could not spare time to be there.

"With the mother's patient waiting

Through the days of outstretched arms

Then for me to attend the races

Their great attraction has no charms.

"The Little Fairies would all miss me,

Through the night, so clear and fair,

With the Angels hovering around them;

No, cannot spare time to be there." 


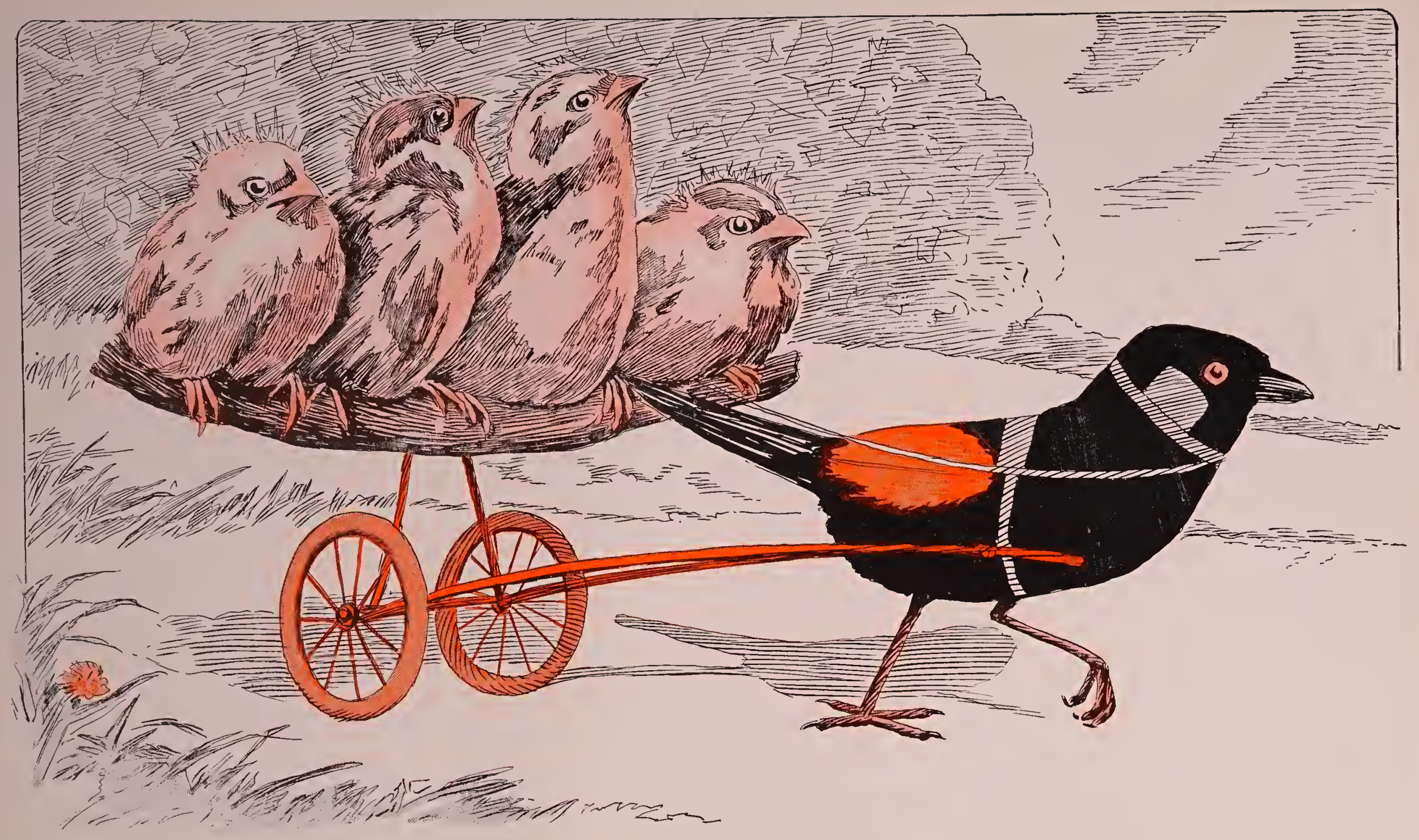

RED-RUMPED TANAGER

"I looked all around

For my babies a place;

Was unable to find one,

So we all go to the race." 

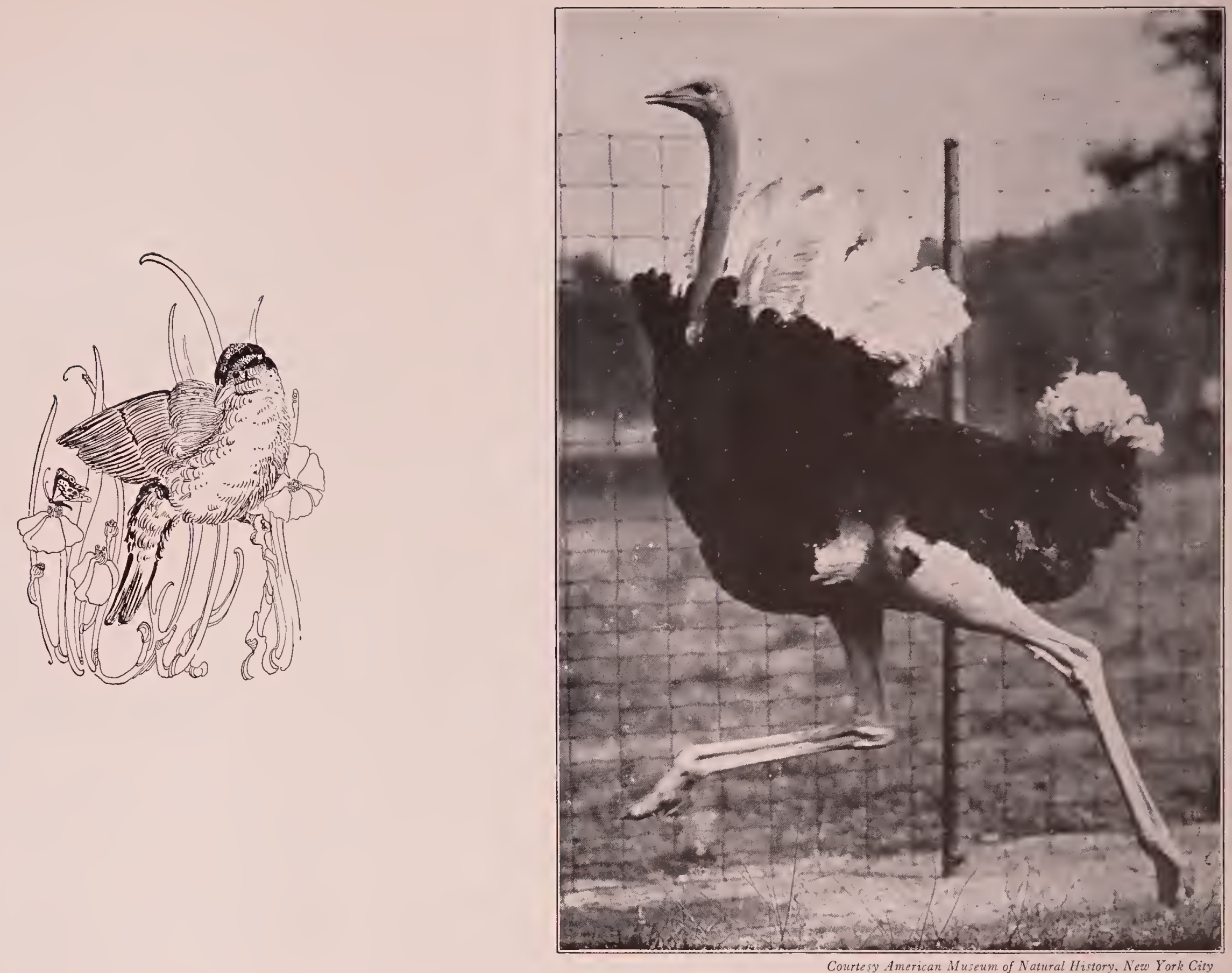

\section{MR. OSTRICH}

"With those small birds it's hard to mix;

As for a foot race they would come out nix If it's for speed they want to rely,

I'll take the ground and let them fly.

"The Eagle says, all things he wants to regulate

So has appointed me to attend the gate.

There are many other jobs I would prefer

But he has already made me Of-fi-cer.

"If any of those speed birds show up late

I sure am going to close the gate,

As I have longed with my heart's desire

To watch those little birds come under the wire."

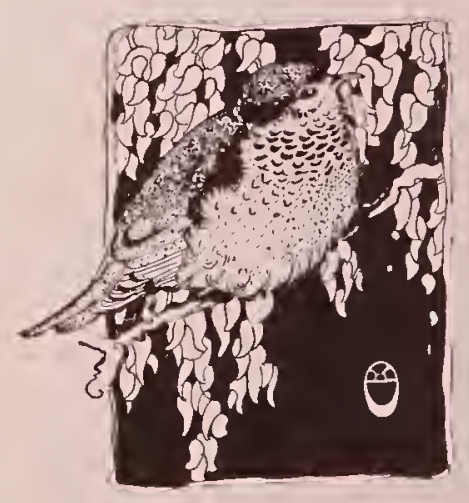




\section{WOOD PEWEE}

"I've looked through the rules

While in Bird Town to-day.

There is nothing on record

Against my running this way.

"I don't think other birds

Will stand much of a show,

As I will be there on time,

Ready for the word 'Go.'

"The only thing I'm afraid of,

Or could worry about,

The Police Bird and Eagle

Might both rule me out.

"I'm going to go anyhow:

All the birds I will lead,

If they don't rule me out

I will show them some speed."

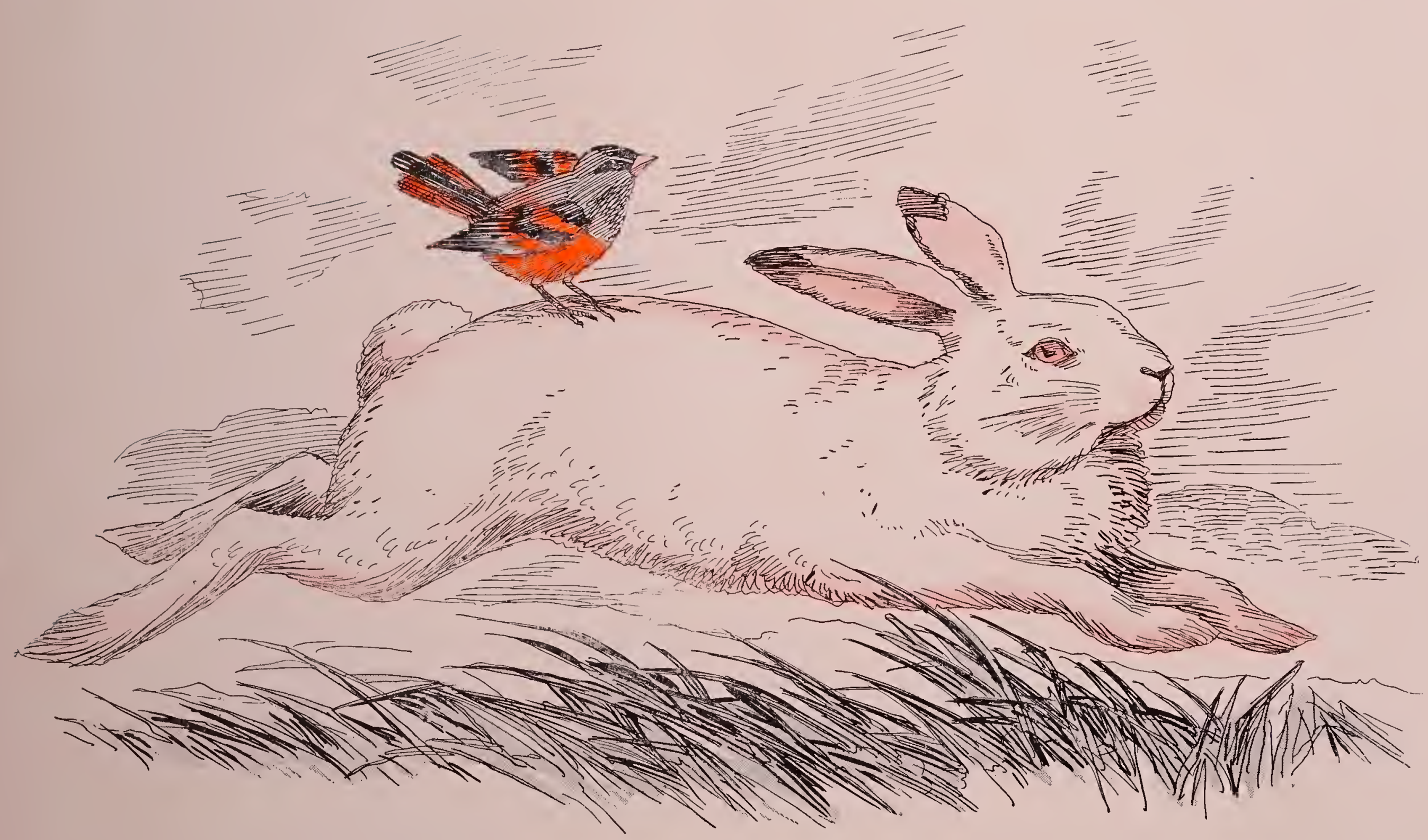




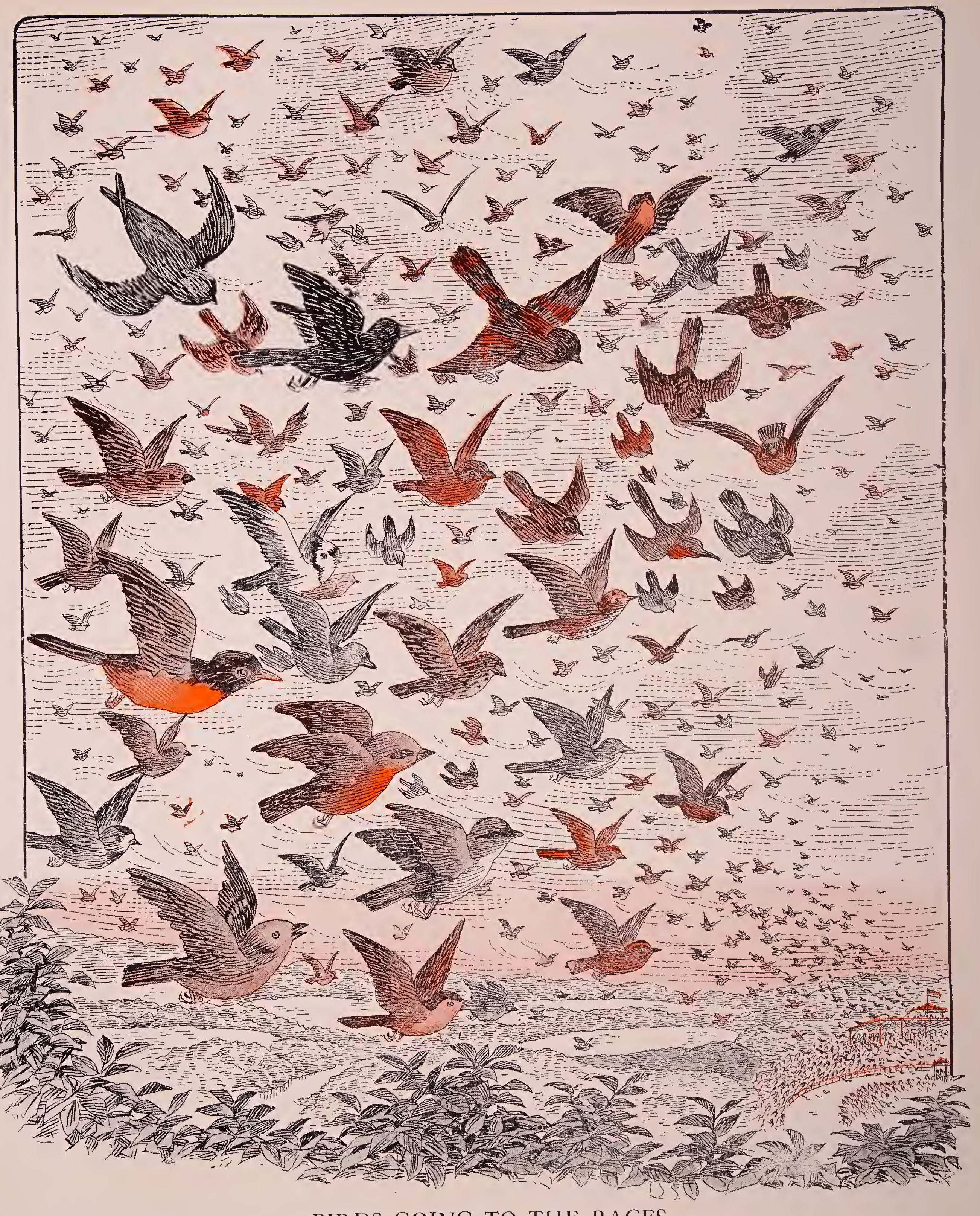

BIRDS GOING TO THE RACES 


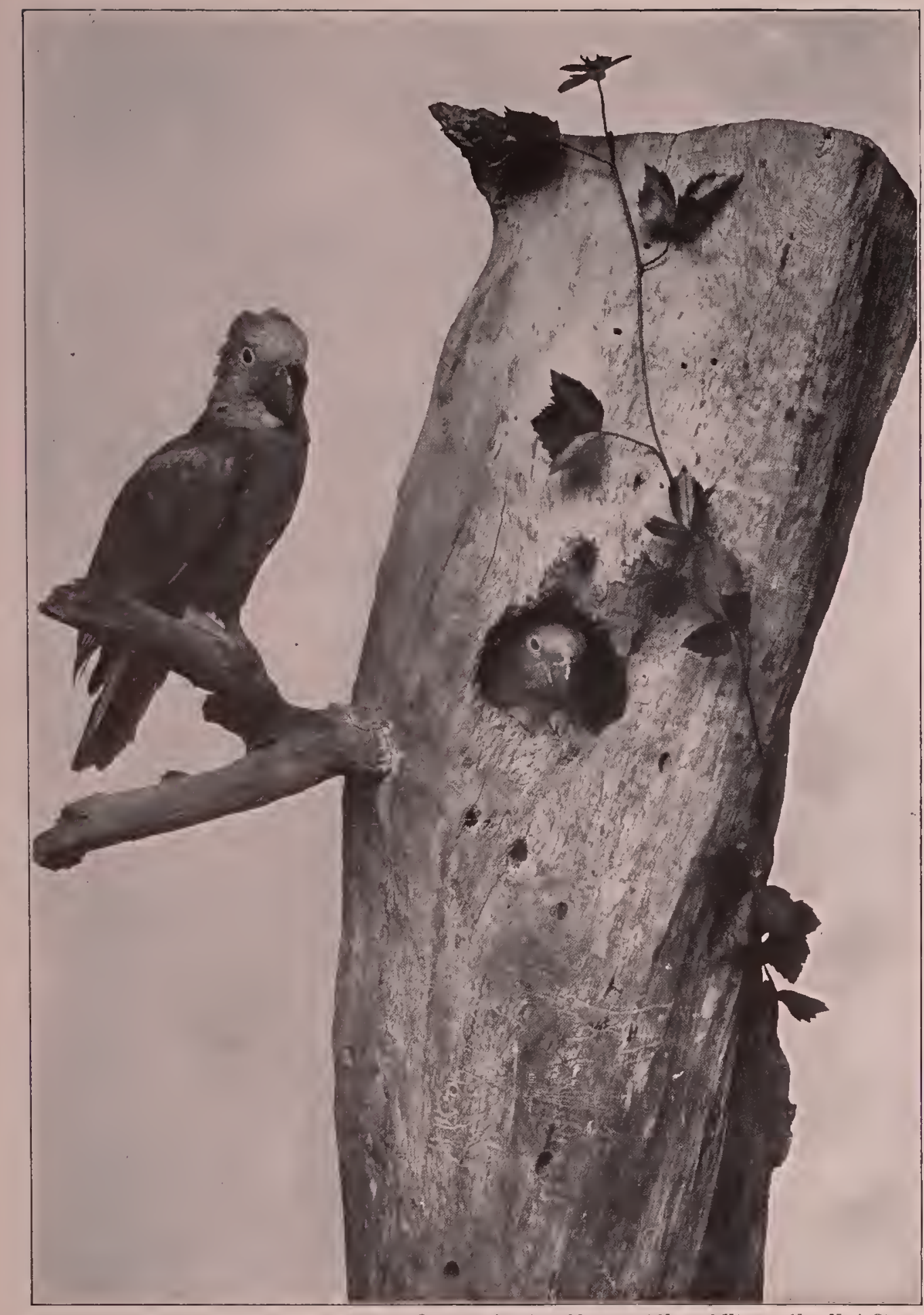

Courtesy American Museum of Natural History, New York City PARROT

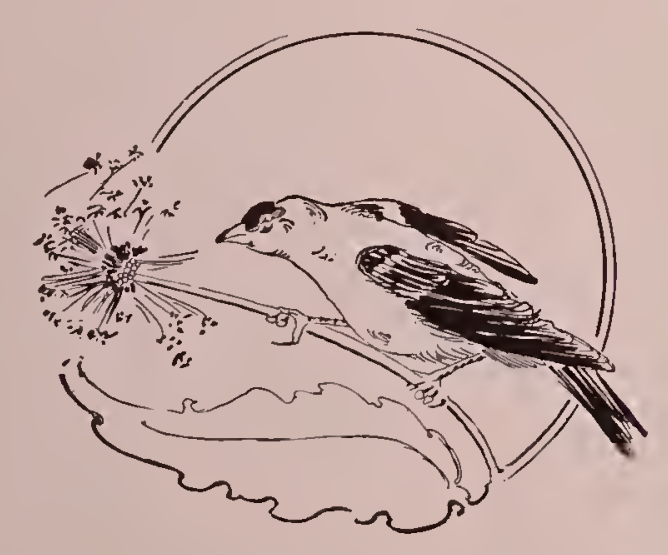

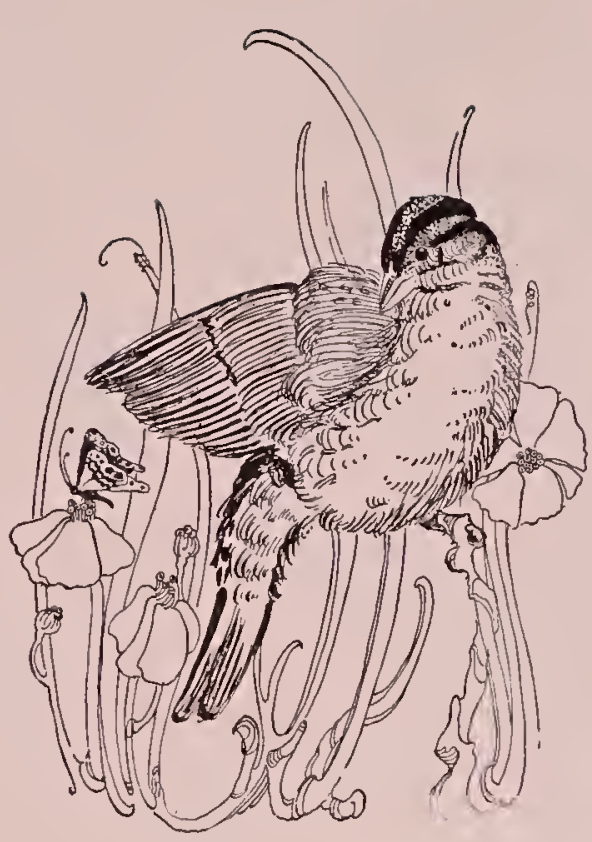

\section{PARROT}

"I'll come," said the Parrot, "At my very slow pace. I have been chosen by the Eagle To say 'Go' at the race.

"I've been a favorite among children For a great many long years, And no word gets by me But what stays in my ears.

"A great many birds chirp me For my very slow walk, But I am the only bird That can really talk." 


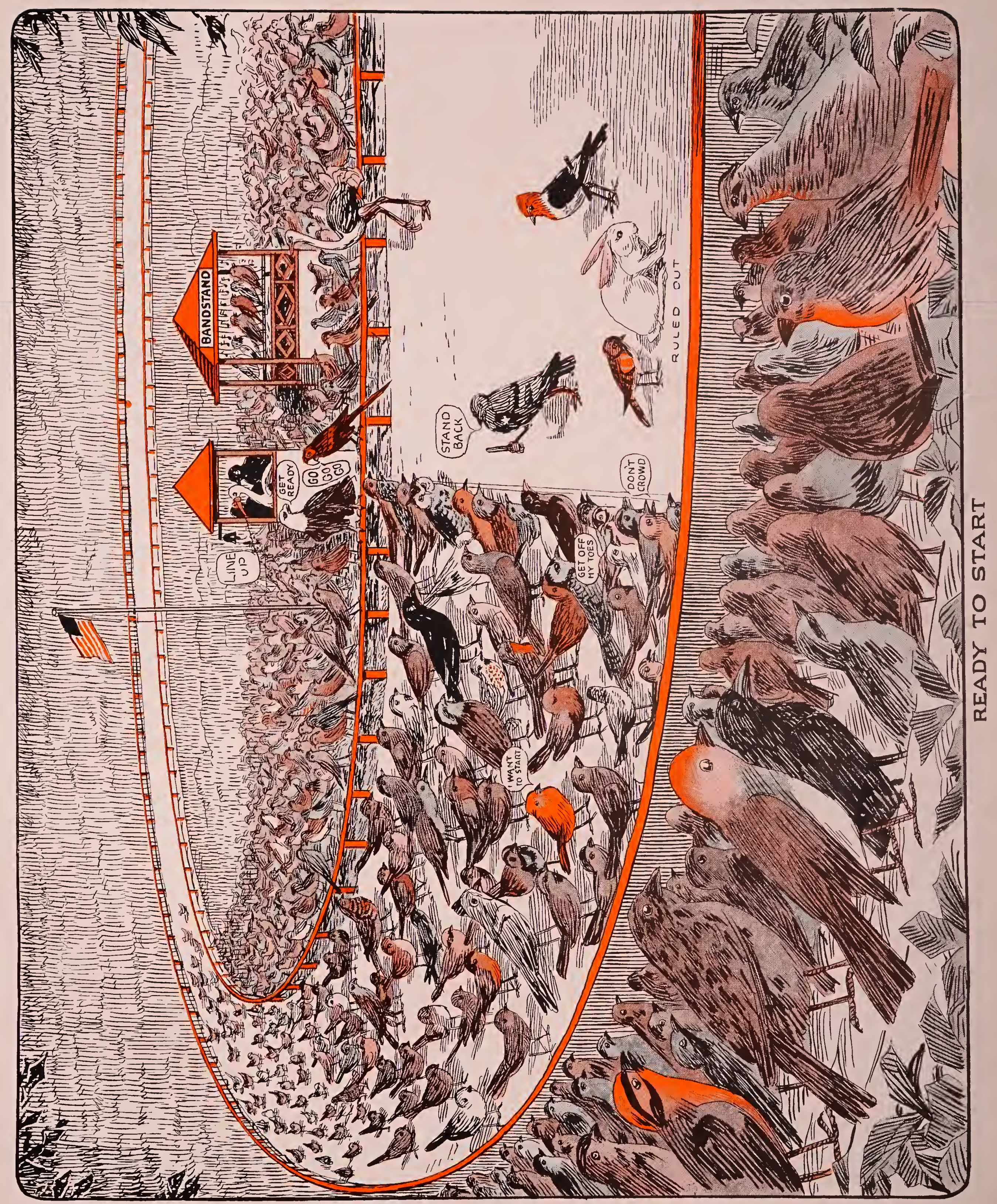



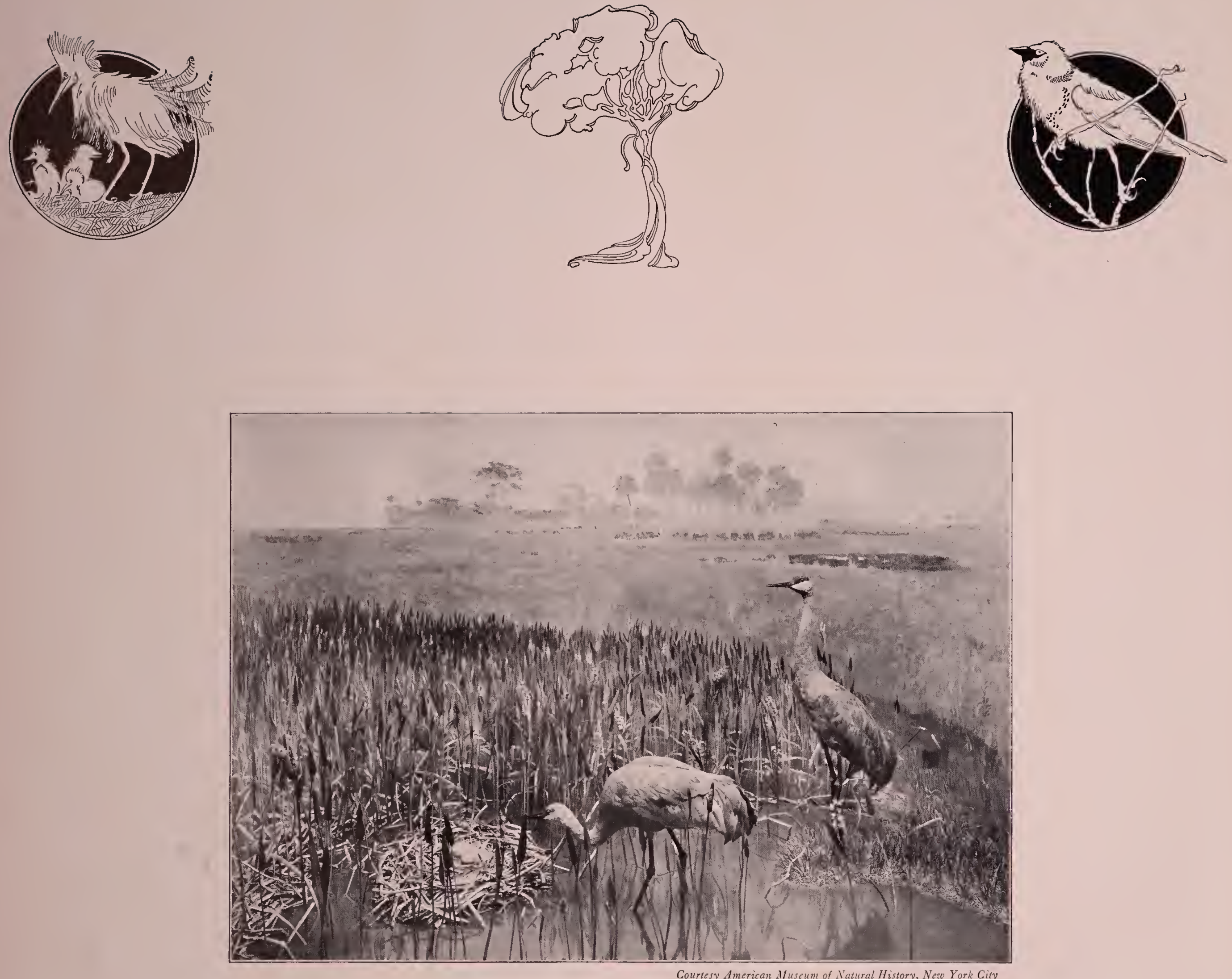

JUDGE CRANE

"I am ever old faithful Judge Crane.

Every day seems to bring me more fame. Will take my place at the birds' foot race, And hereafter be known as Judge Crane.' 


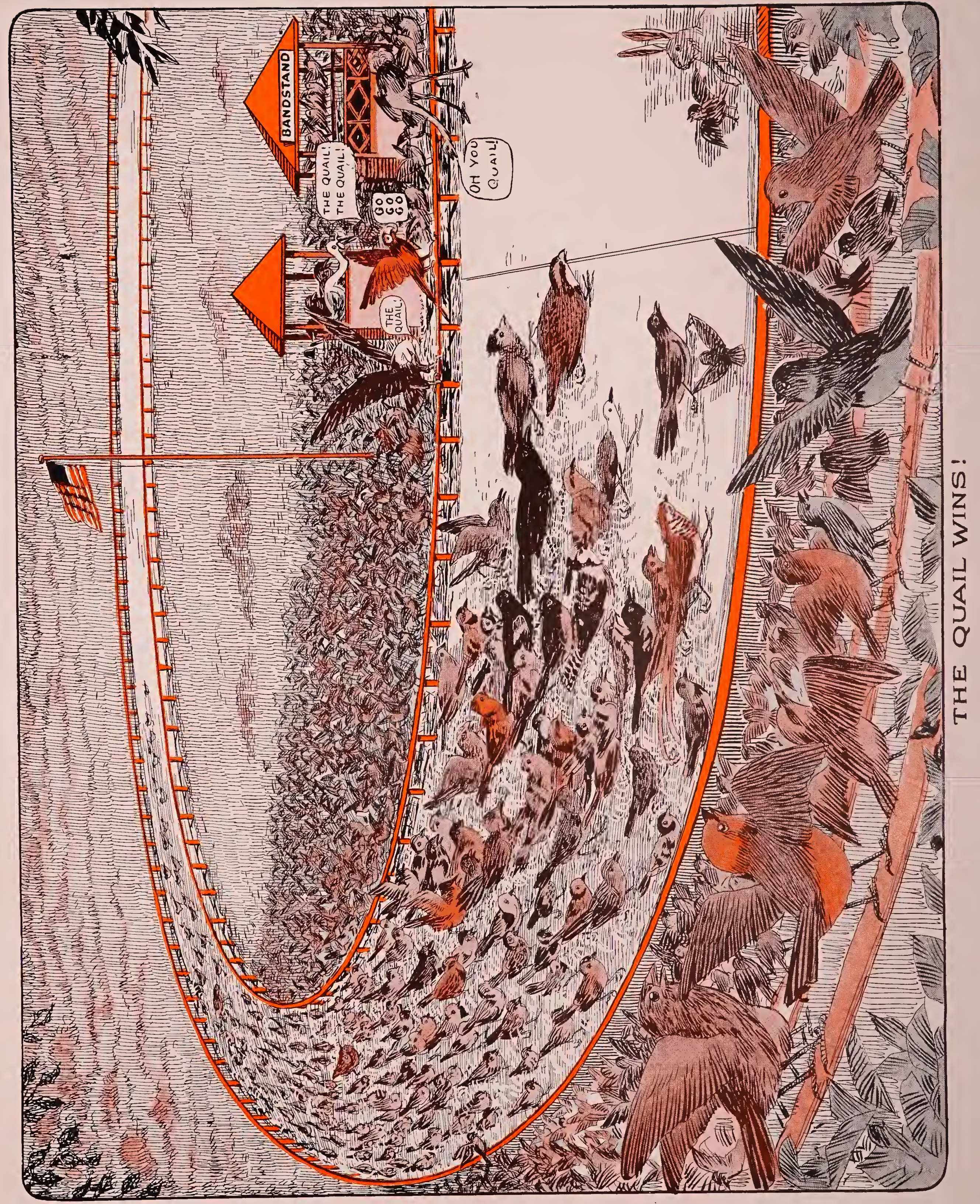




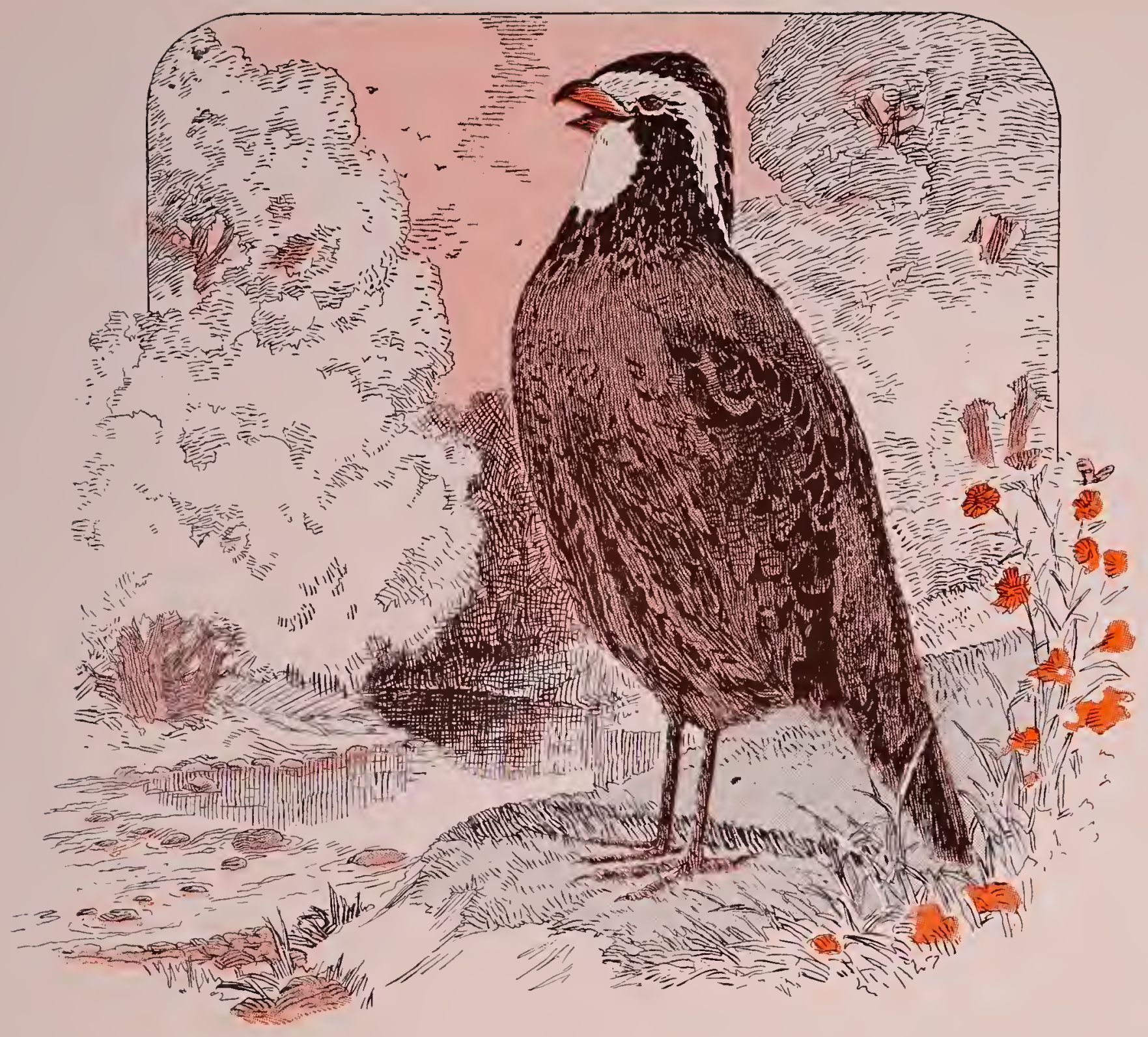

THE WINNER OF THE PRIZE

"Need I say that I'm proud? You can read it in my face; They are shouting aloud That I've won the foot race.

"Come down to the brookside I very much thirst

To tell all my kinfolks

That I came out first.

"Our old friend the Owl Of course, couldn't see. Not knowing that all eyes Were turned toward me.
"So he shouted again, 'Ho. Ho. Whoo'; Says the Partridge to me, They're shouting

'Tis you, 'tis you';

"Now this is the most pleasing Part of the tale;

To hear Judge Crane shout

'The winner, Quail, Quail!'

"With modest mien and grace profound I'll accept the prize fresh from the ground. While my appetite calls not for worms I'm always fearful of catching germs.

"However, I'll take it, 'twill

Not make me vain

And I'll divide with my neighbors

In exchange for grain.” 


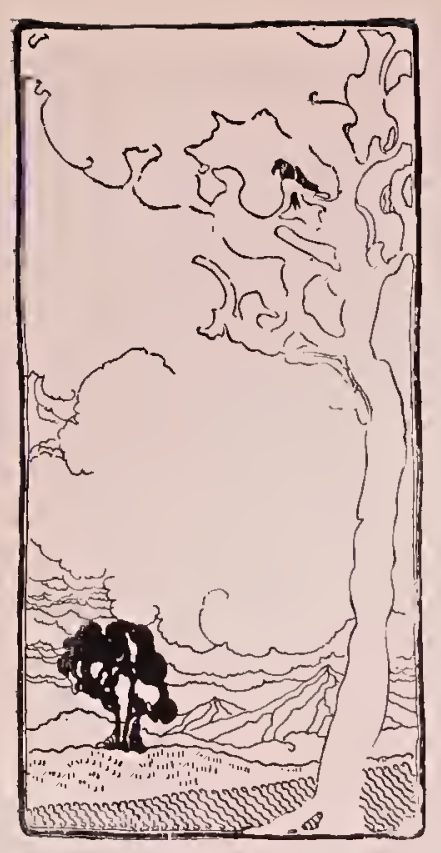

\section{TREE SPARROW}

"To have won that race

Would have been a sure thing

If I had not tumbled down

And broken my wing.

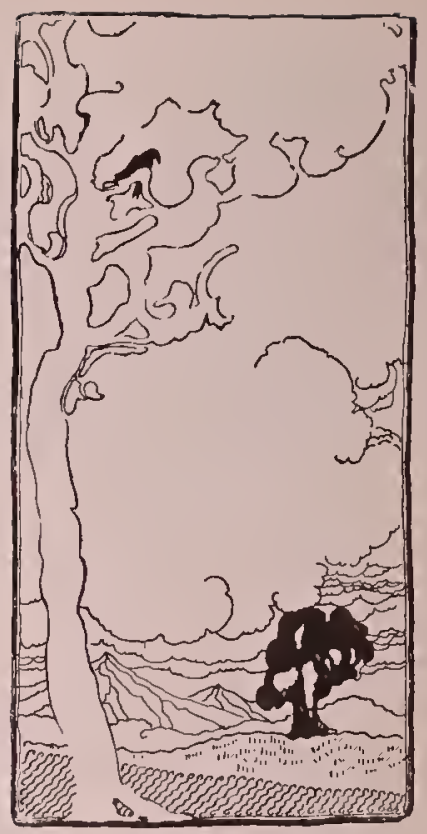

"Now I'm all crippled up,

As you can plainly see,

And will stay a long time

In the Hospital Tree."

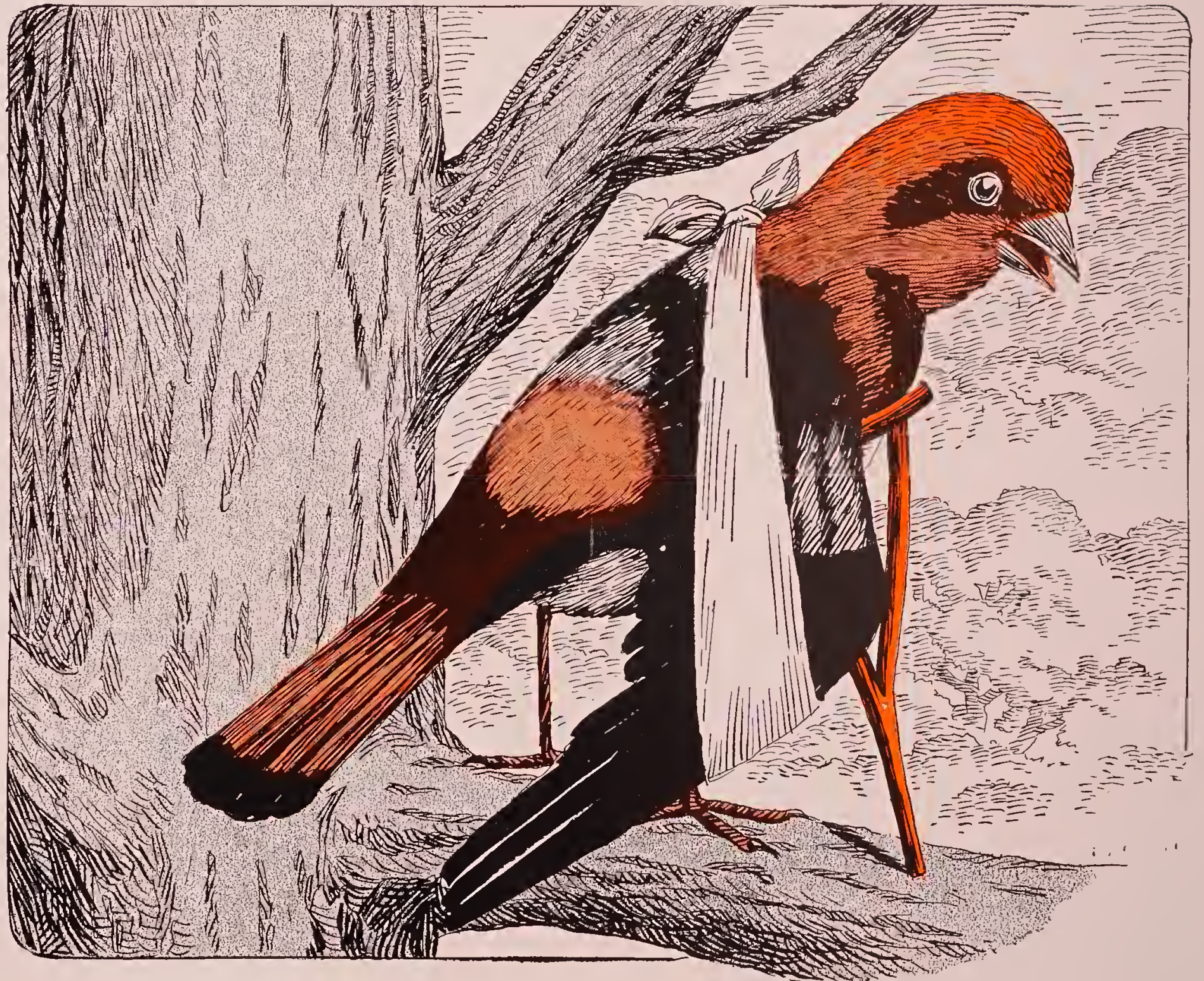



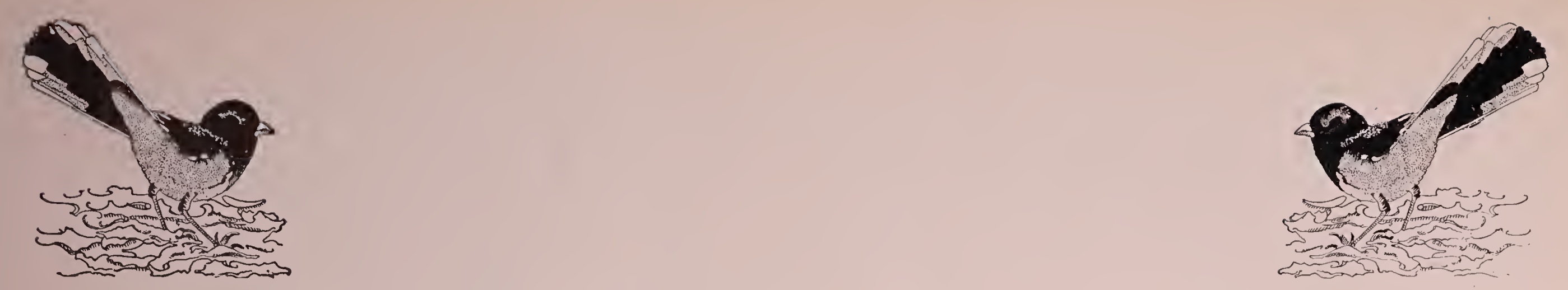

\section{KINGBIRD COMMENTS ON THE RACE}

"When the race first started I was right in the lead, And when that Quail passed me He was showing some speed.

"He must have been practicing A long time in advance, Couldn't see where other birds Had much of a chance.

"There were some birds that passed me, I think Partridge and Thrush,

But I would not be sure As I saw nothing but dust.
"I think 'twould have been better For all birds in the town If they made some arrangements And had the track sprinkled down.

"The Crow made a good showing And the Blackbird as well; But lots of birds I lost track of Even Judge Crane couldn't tell.

"I was very much interested In the movement of the Hawk He was much overrated And could do nothing but walk.

"Now, back to the mountains

I'll make my home flight

And be content with the foot race

But hold my record for fights."
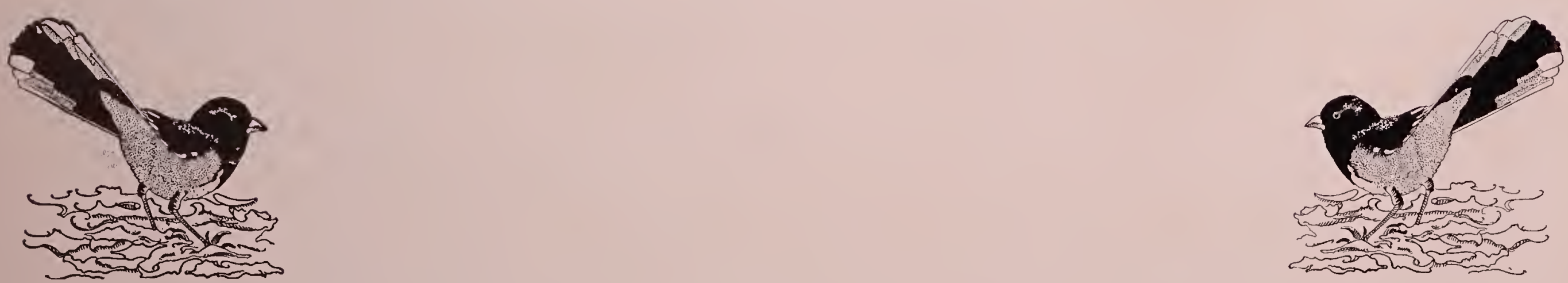


\section{RED-RUMPED TANAGER}

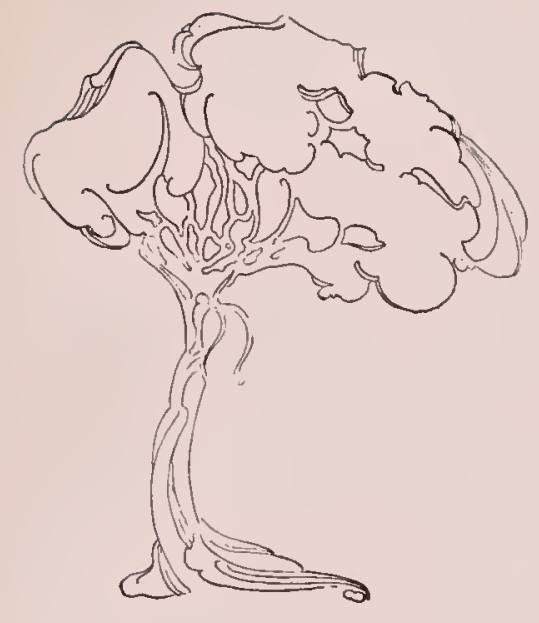

"When I got to the races

Could not find any bed

So I'm taking my babies

Back to their home dead.

"The track got so dusty

Their walks were so narrow

I am taking my babies back

In a little wheelbarrow.

"When this is all over

A new life I will begin

But I'll never take babies

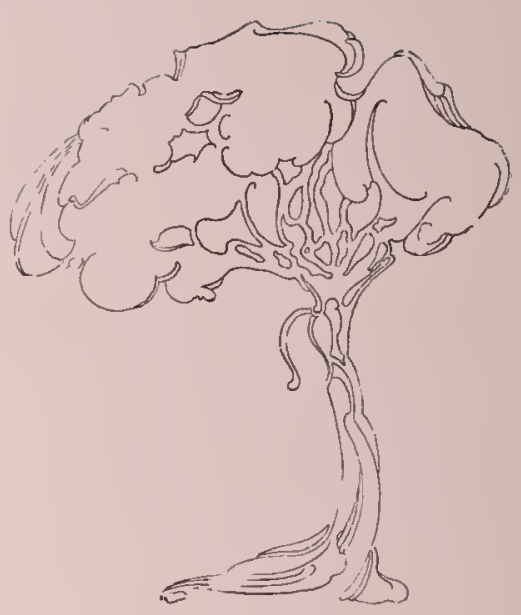

To foot races again."

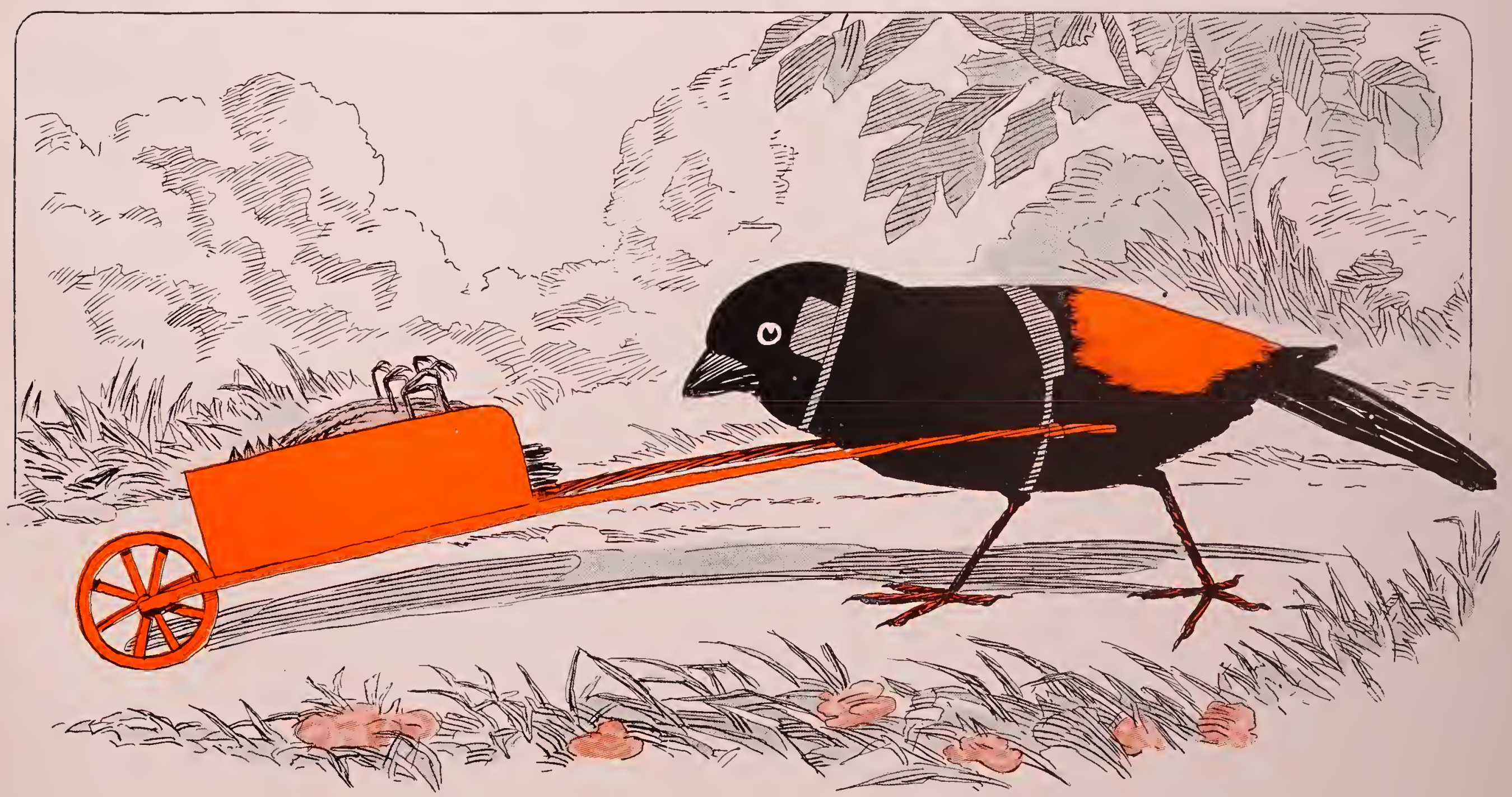



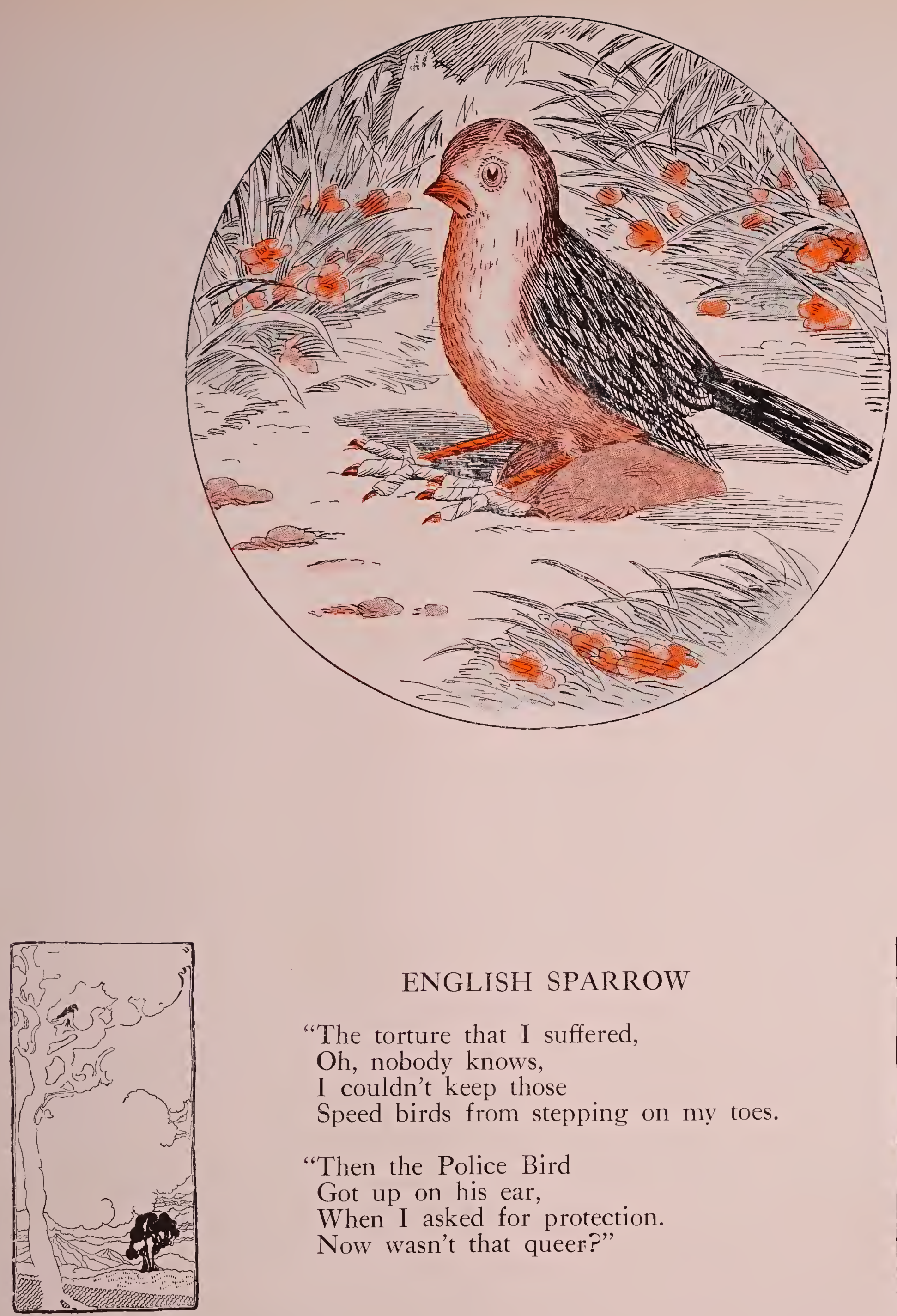

\section{ENGLISH SPARROW}

"The torture that I suffered,

Oh, nobody knows,

I couldn't keep those

Speed birds from stepping on my toes.

"Then the Police Bird

Got up on his ear,

When I asked for protection.

Now wasn't that queer?"

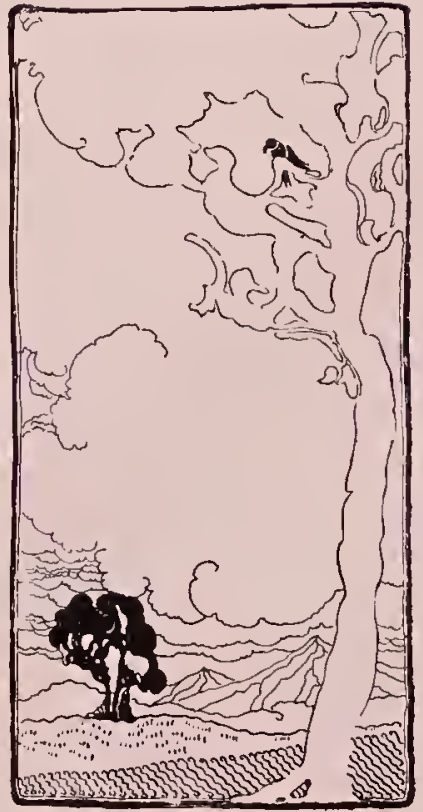



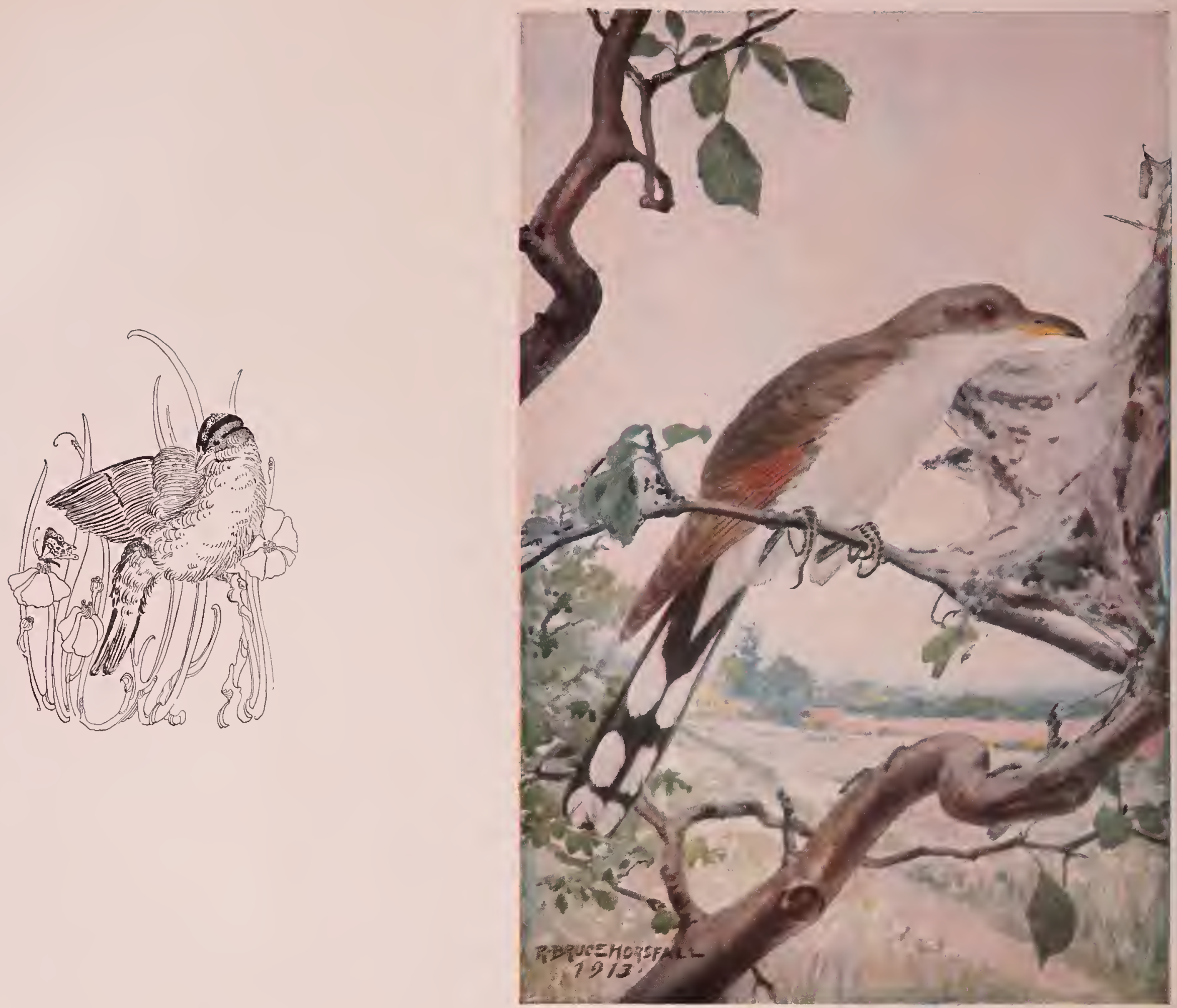

YELLOW-BILLED CUTKOO

YELLOW-BILLED CUCKOO

"Who ever started that foot race for bird? Such an unreasonable thing no one ever heard; Guess they thought we would do anything for a prize Even go to the extreme of risking our lives."

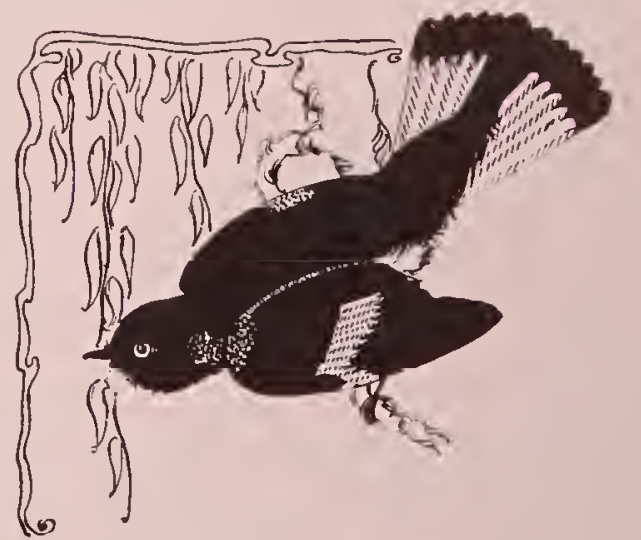



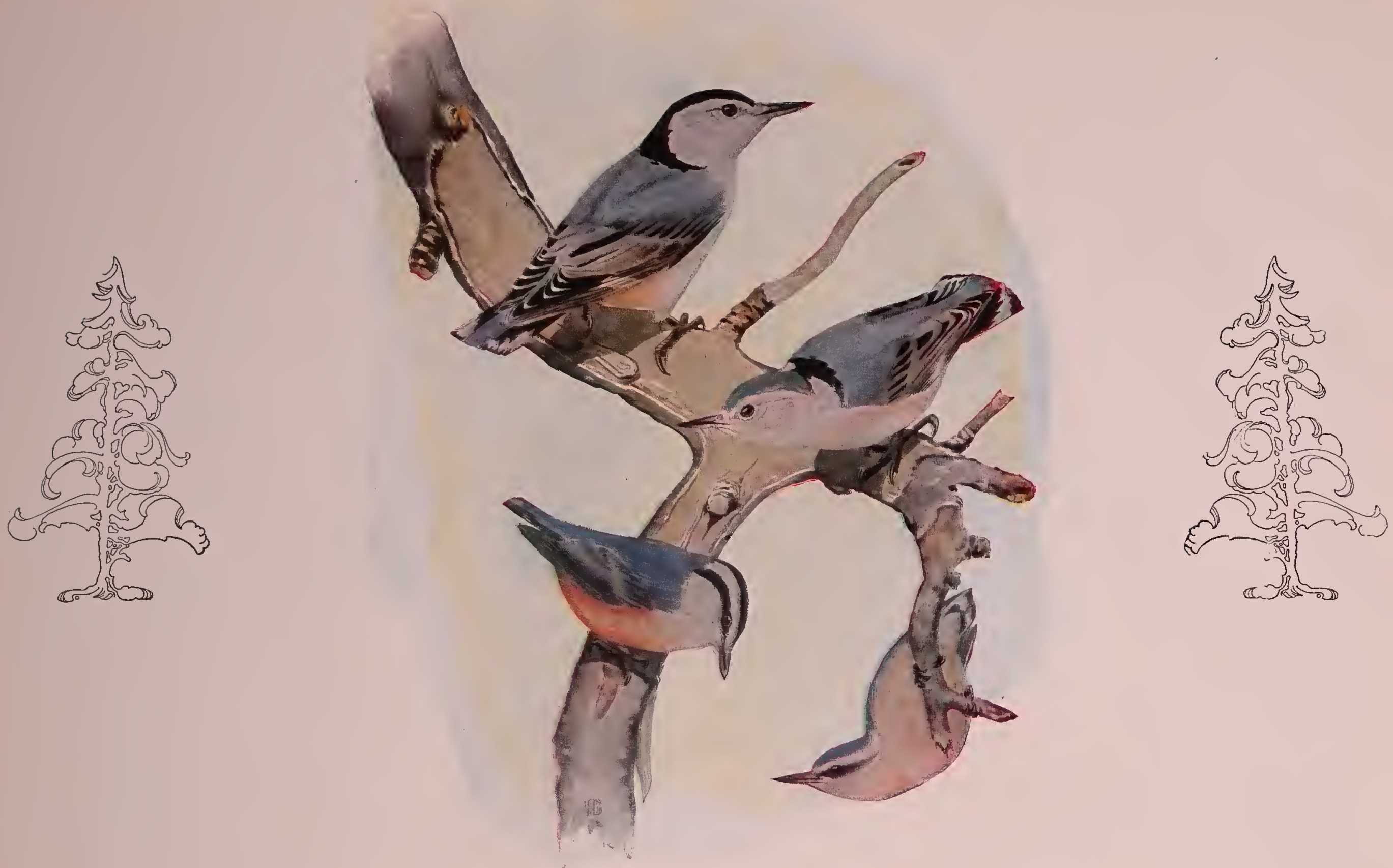

\section{WHITE-BREASTED NUTHATCH}

"In the birds' foot race

I was away back behind,

Now I have such a headache

I'm afraid I'll go blind.

"The Parrot talked so much

Before he could say 'Go'

I knew right from the start

I wouldn't stand any show.

"Then the Assistant Police

Took up the whole track

When I got to the front

He would yell 'Stand back.', 

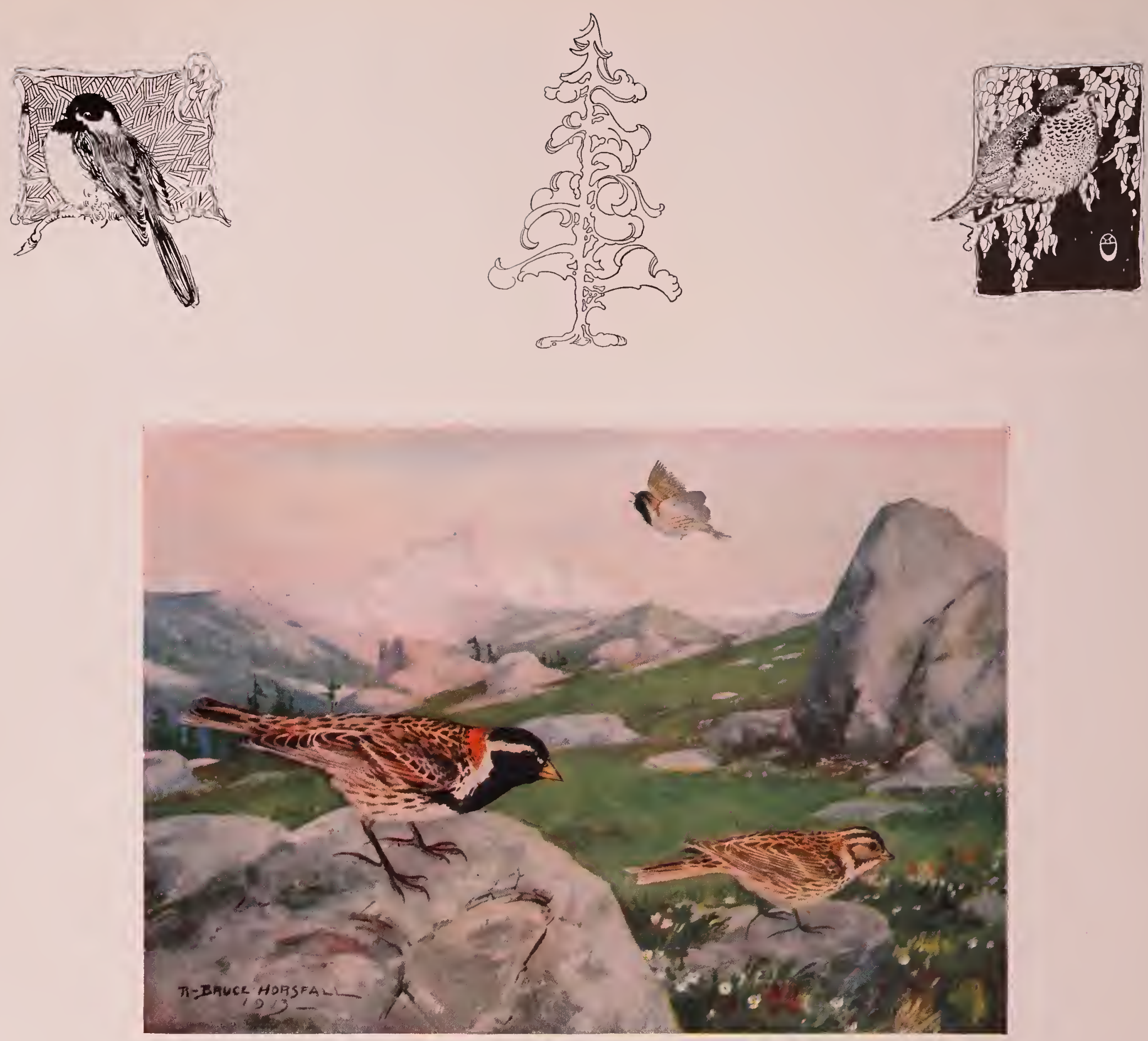

\section{ALASKAN LONGSPUR}

"What was the trouble with the Parrot? I guess we will never know.

He strutted around the grandstand And kept yelling 'Go, Go.'

"It made such a confusion With all the birds on the track, We went straight to the Eagle To get our entrance fee back.

"Then we went to the grandstand To listen to the band, The music was so catching We just took a hand." 

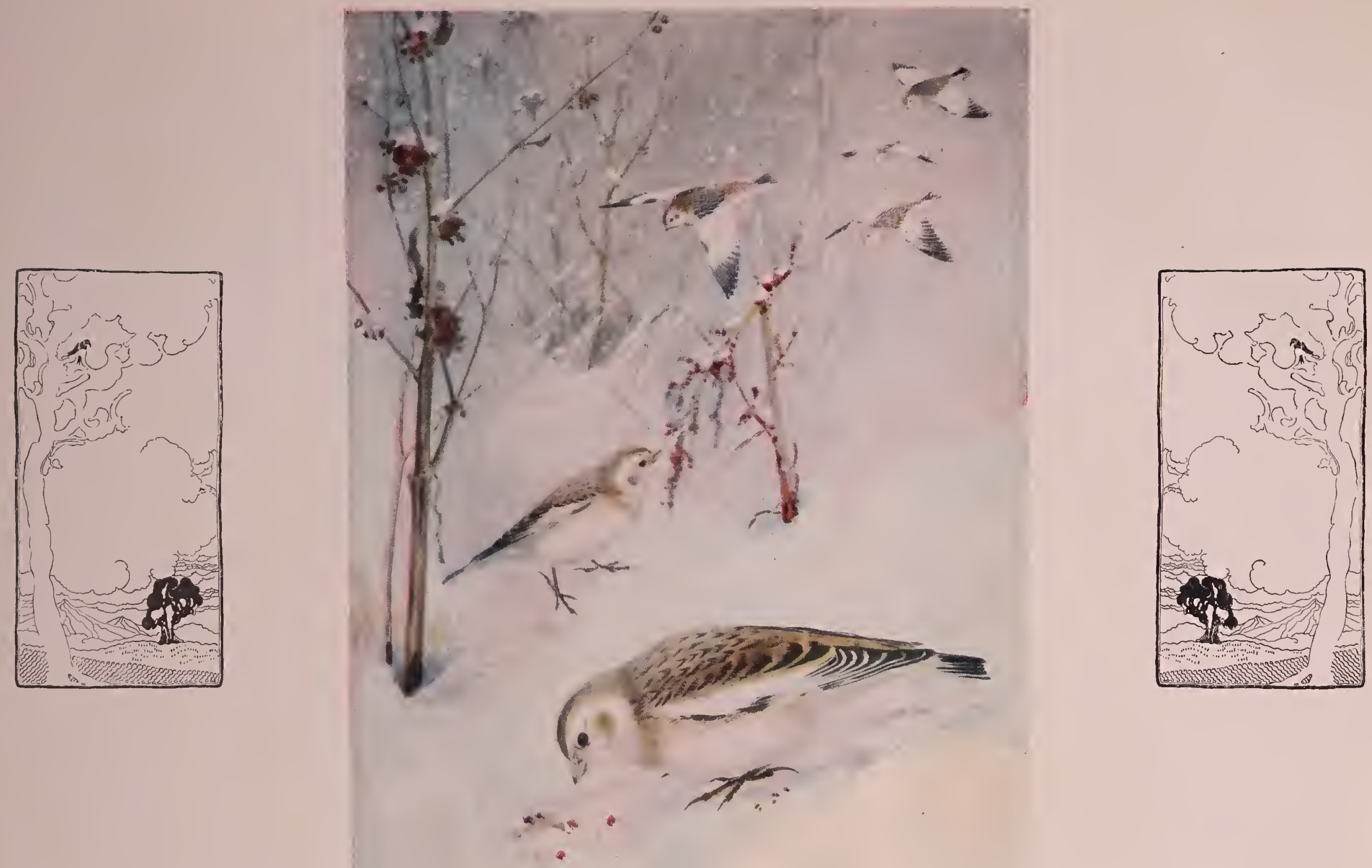

\section{SNOW BUNTING}

"The balance of my life

Will be an awful loss

To know why the Eagle

Made such a poor boss.

"The partiality he showed

Will make a lot of talk

For I caught him whispering

To both the Quail and the Hawk.

"But there's no use a-talking

We all had lots of fun

And that little old Quail bird

Was sure good on the run." 

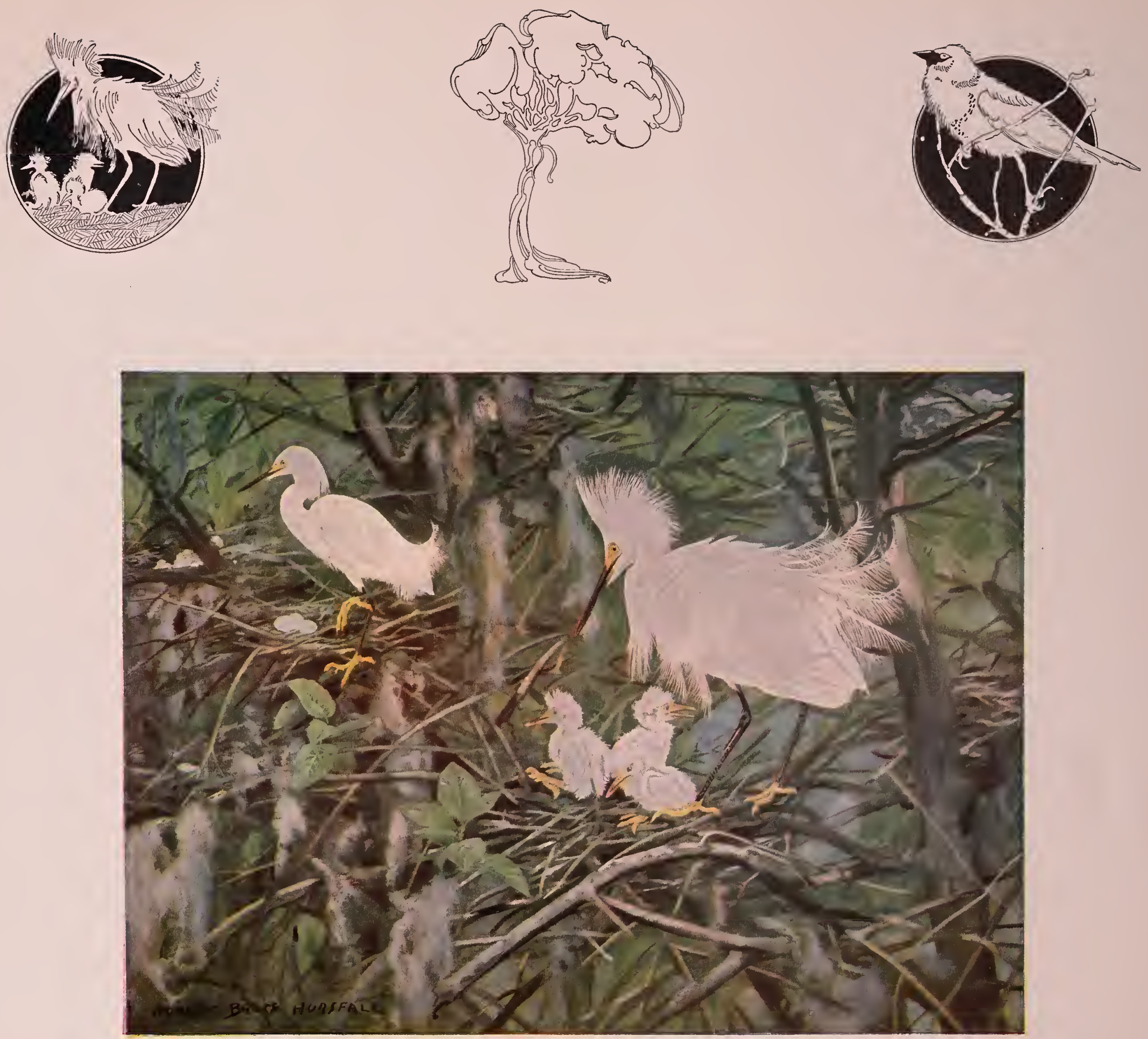

\section{SNOWY EGRET}

"I saw a lot of birds there

A-playing in the dirt,

There was one or two of them

That was trying to flirt.

"I sure was watching them

For the stride they laid

And was keeping a close watch

On my dear little maid." 


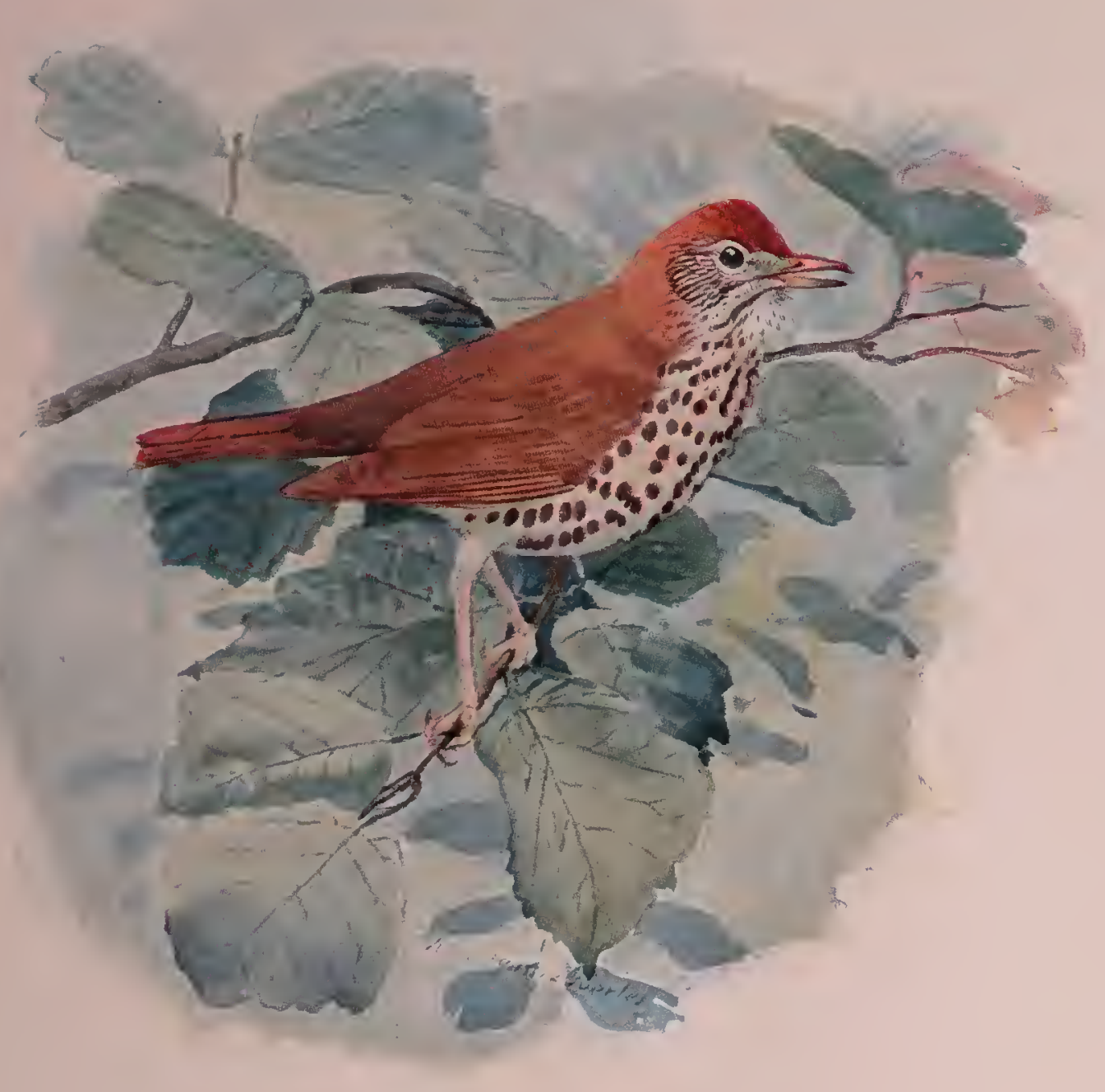

WOOD THRUSH

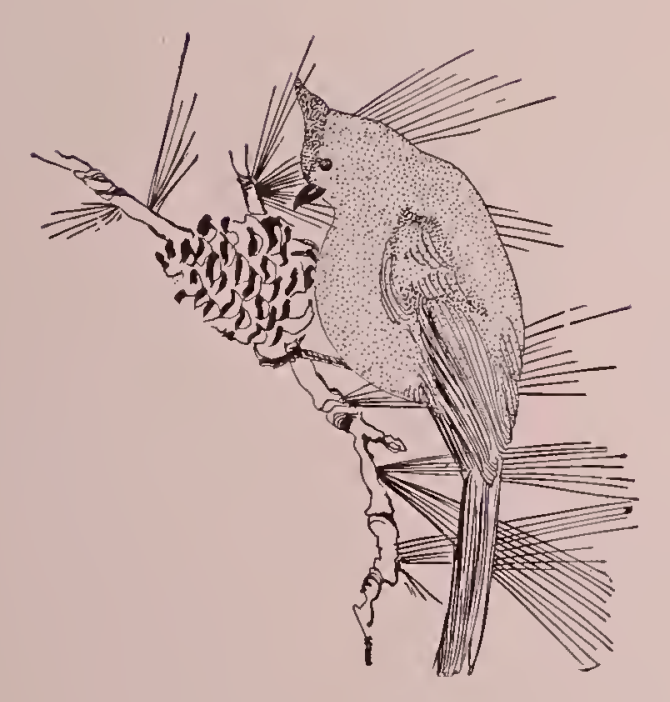

\section{WOOD THRUSH}

"Where was the old Ostrich? He must have been late, As I did not notice Any one at the gate.

"I do think the old Eagle Overlooked the size of his hat To appoint for a Gate Bird A big buffer like that." 

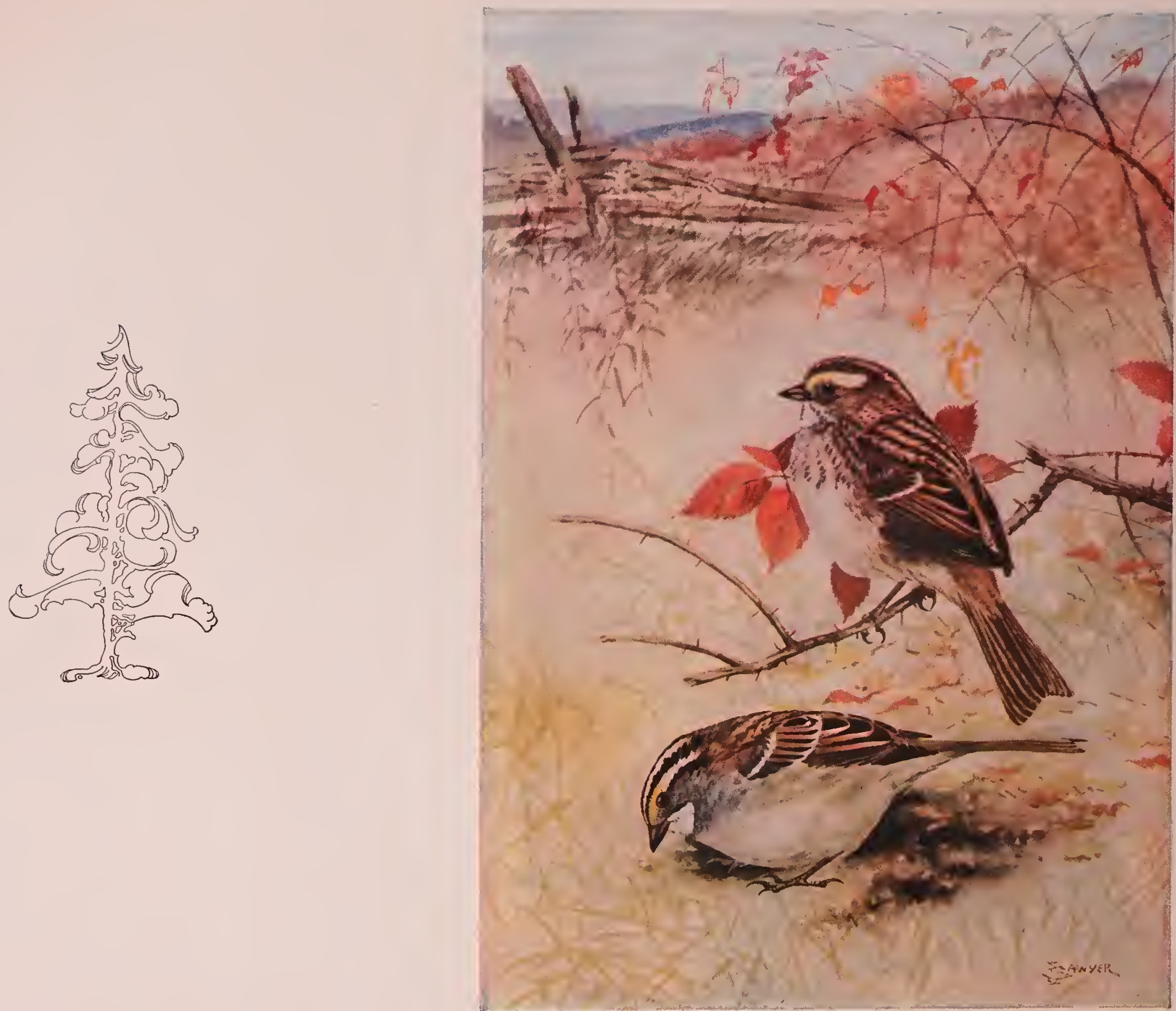

WHITE-THROATED SPARROW

\section{WHITE-THROATED SPARROW}

"We were over at the Bird Hospital Just sitting around the edge, There were many birds there Who had broken their legs.

"The old Eagle was there, So the other birds said, But he felt so bad He was going to bed.

"I'm going after Dr. Bird Do you suppose he will come? I don't think he will, As he told us not to run."

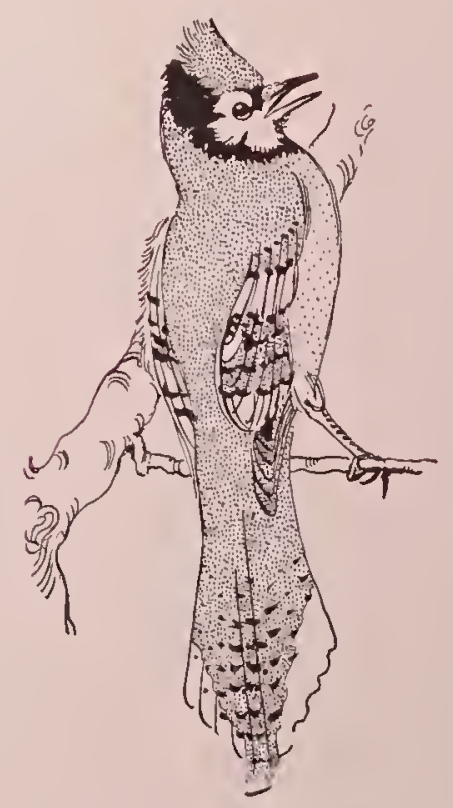



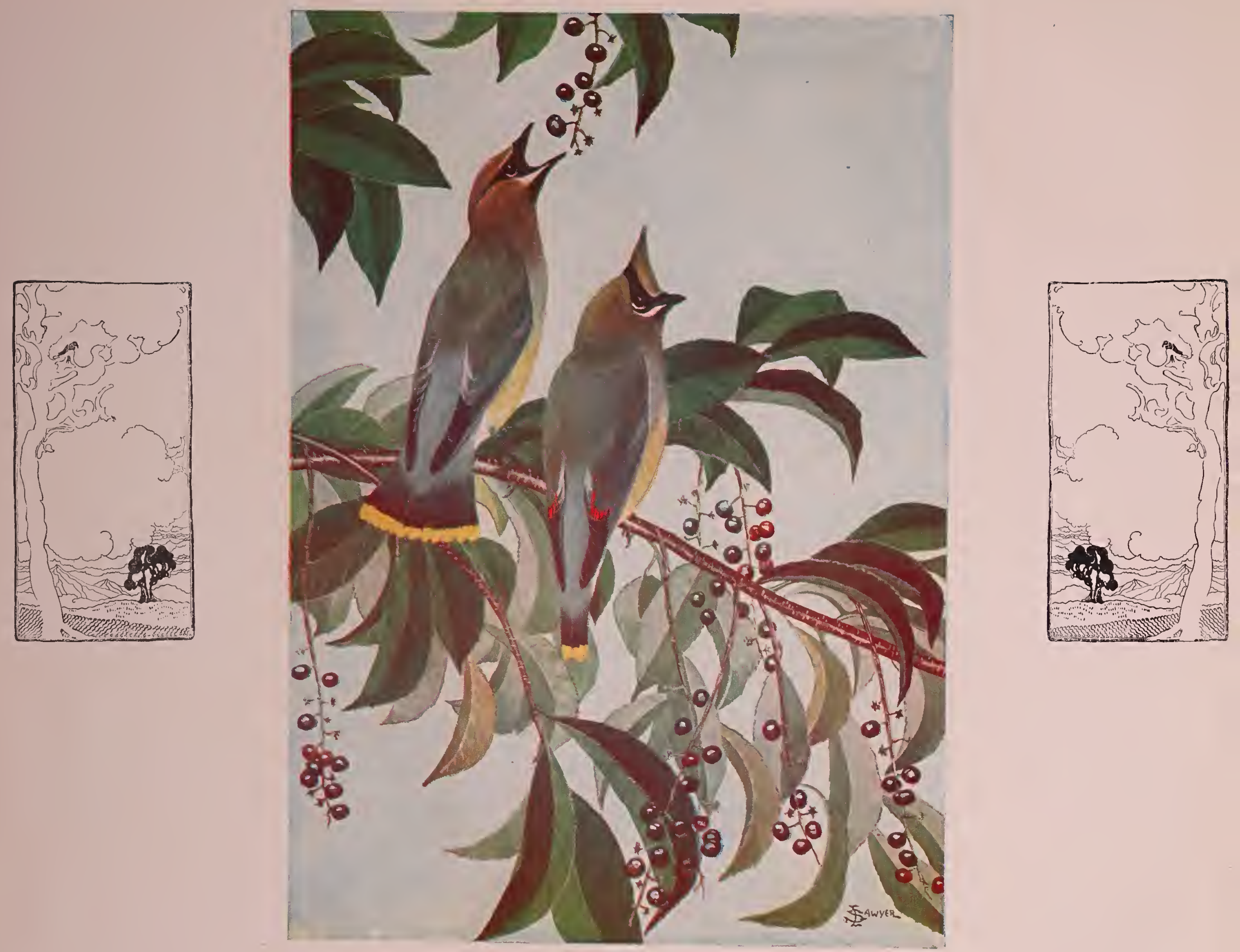

\section{CEDAR WAX WING}

"Did you hear the sad news

Of what happened to the Plover?

He got all crippled up

We think it will last him for ever.

"I'm glad the races are over,

And all excitement like that,

As being down on the ground

Makes my heart go pit-pat." 

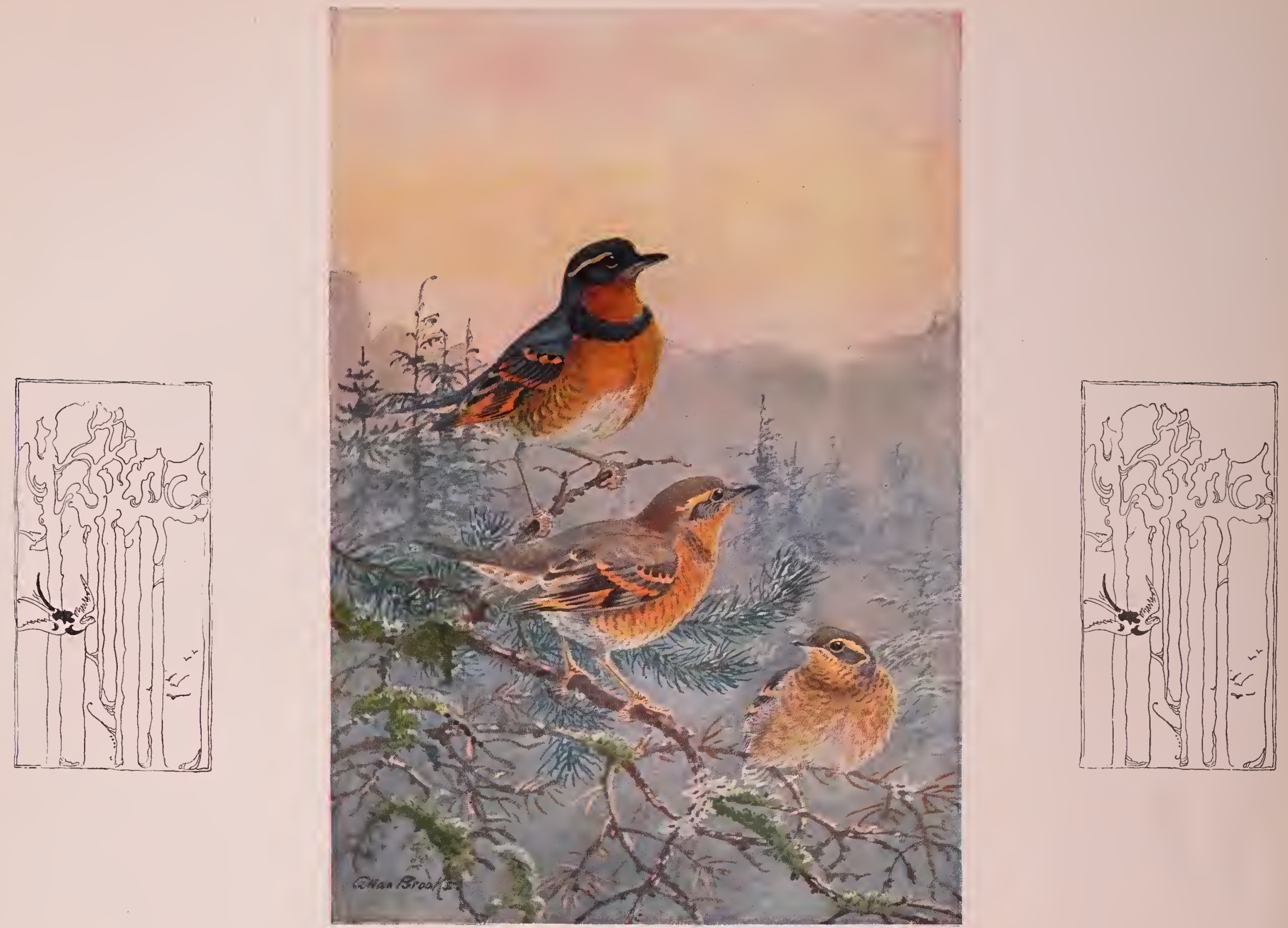

\section{VARIED THRUSH}

"We got so disgusted

When we commenced to get wise,

We lost all interest

In who got the prize.

"Then that big Ostrich

Was only loafing around,

He thinks because he's big,

He can run the whole town.

"With all my experience,

Of standing in line

When I go to a race again

It'll be a long time.

"I talked to the Police Bird

And tried to make peace,

He just ruffled up his feathers

And said 'I'm the Police.' 

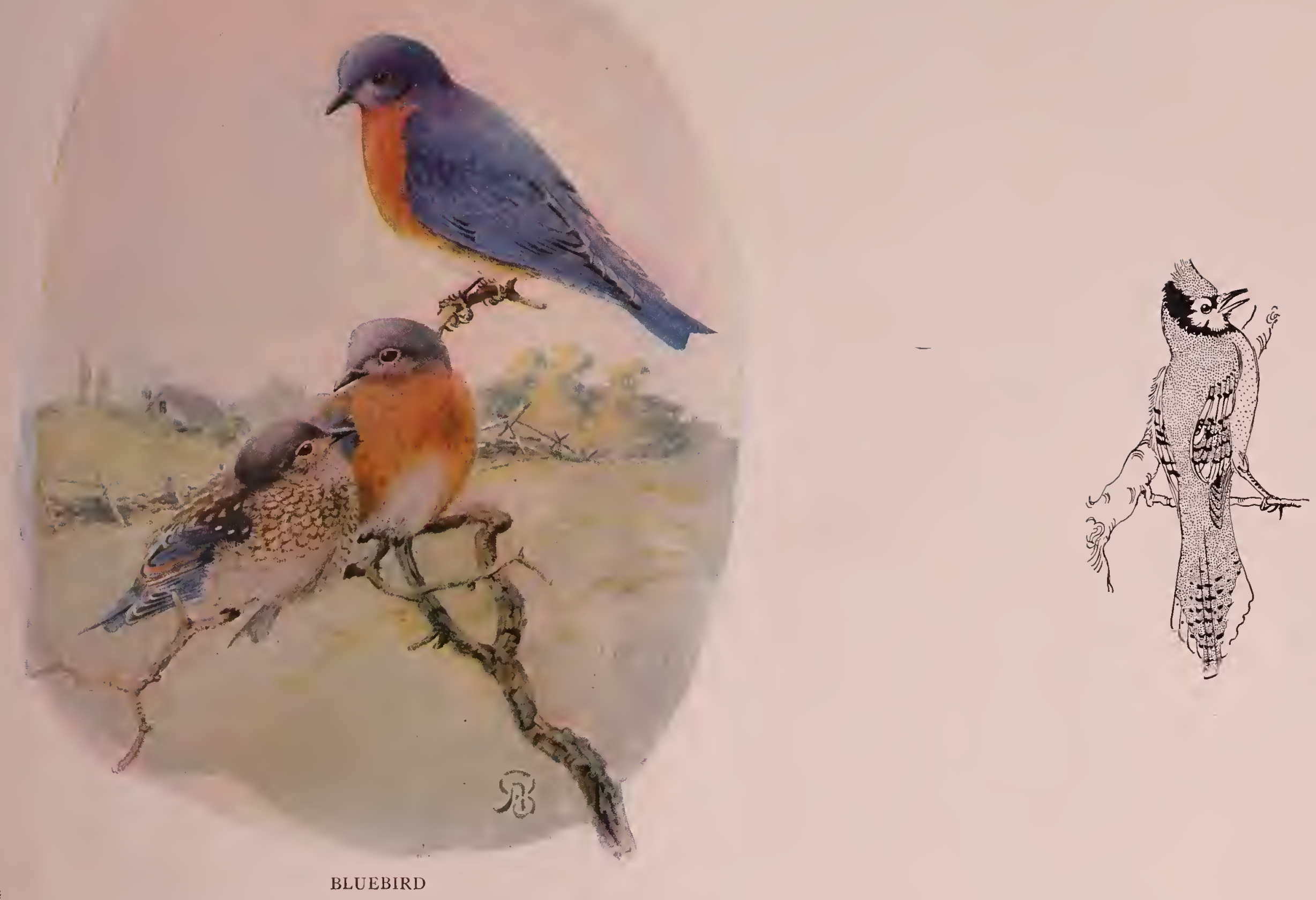

\section{BLUEBIRD}

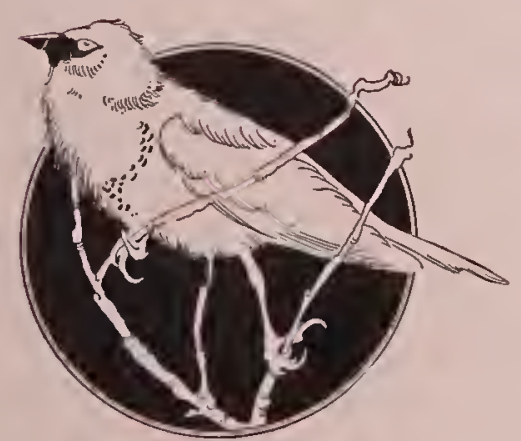

"Oh, that awful foot race That I went to see, Such performance for birds Was a wonder to me.

"I never did think that Birds could be so rude, And there are many of them That I could include.

"Then Judge Crane, and the Eagle For good order they bid, But each of them acted Like a naughty kid." 

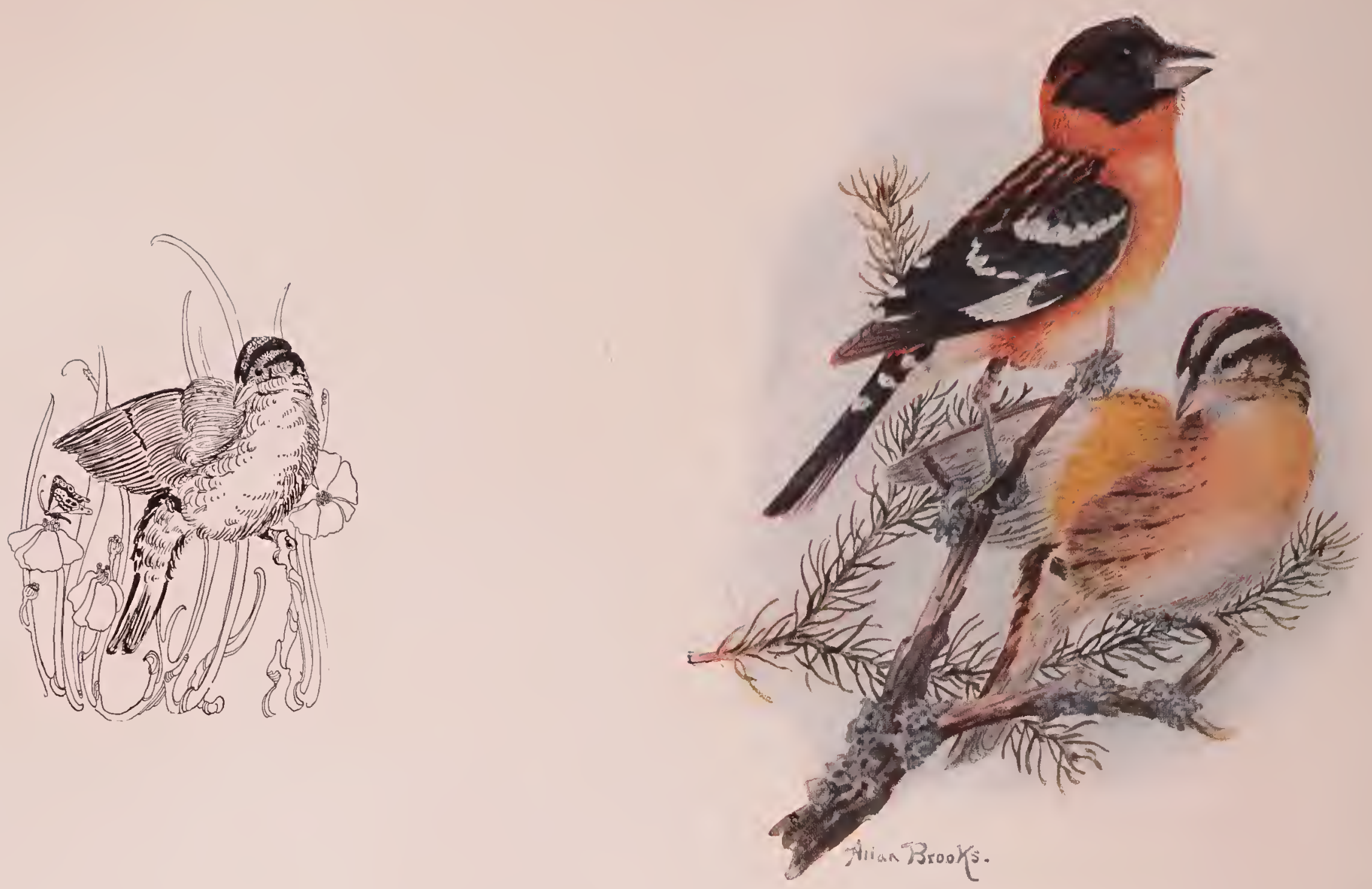

BLACK-HEADED GROSBEAK

\section{BLACK-HEADED GROSBEAK}

"We stood around the race-track Trying to find some shade. Came nearly getting intoxicated On their red lemonade.

“'Will you have another sip,' Says the Bobolink,

'You look very thirsty,

We like to see you drink.'

"Then the dear old Grackles

Were very sociable, too,

They were good help for Eagle In putting the races through."

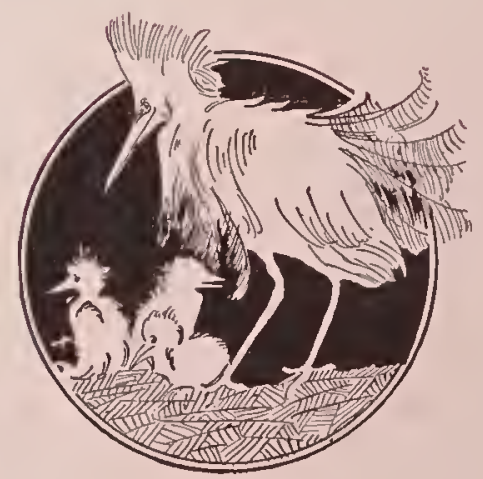




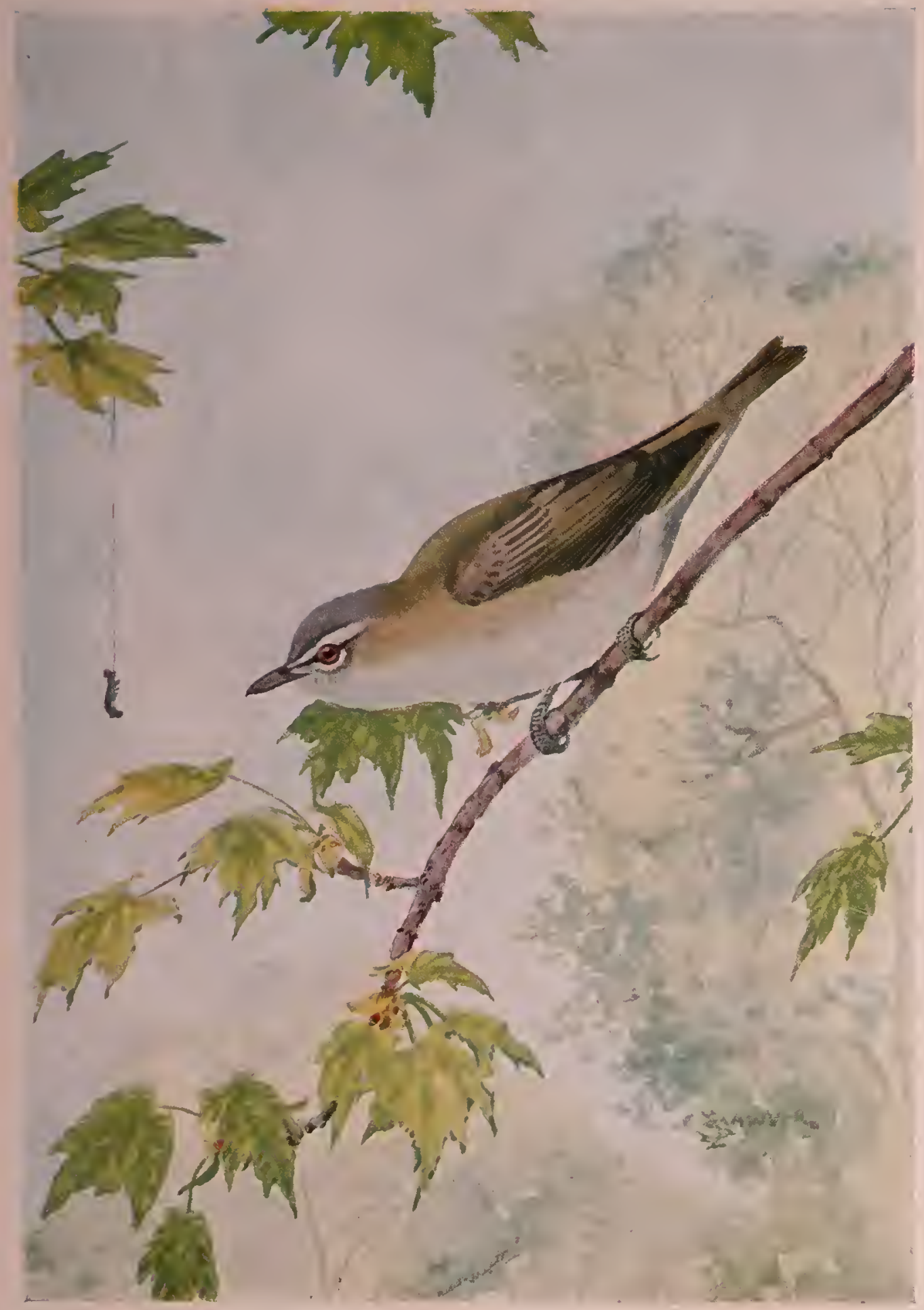

RED-EYED VIREO

"I lost out on the race prize, For a good meal was my hunch, Guess now I will be satisfied With a very light lunch."
"That was a good prize Don't care what they say But before I could get to it The worms all crawled away."

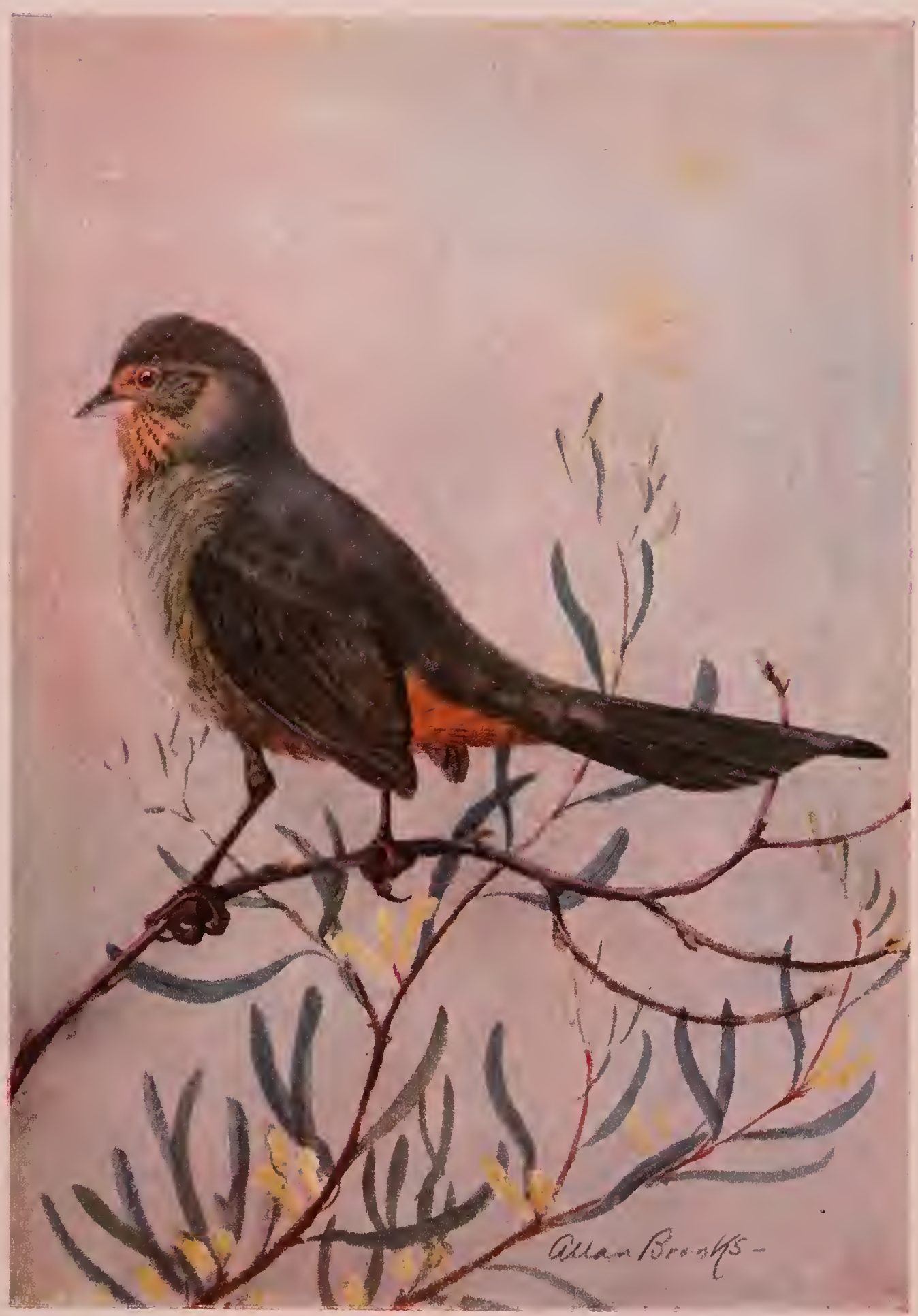

ANTHONY'S TOWHEE 

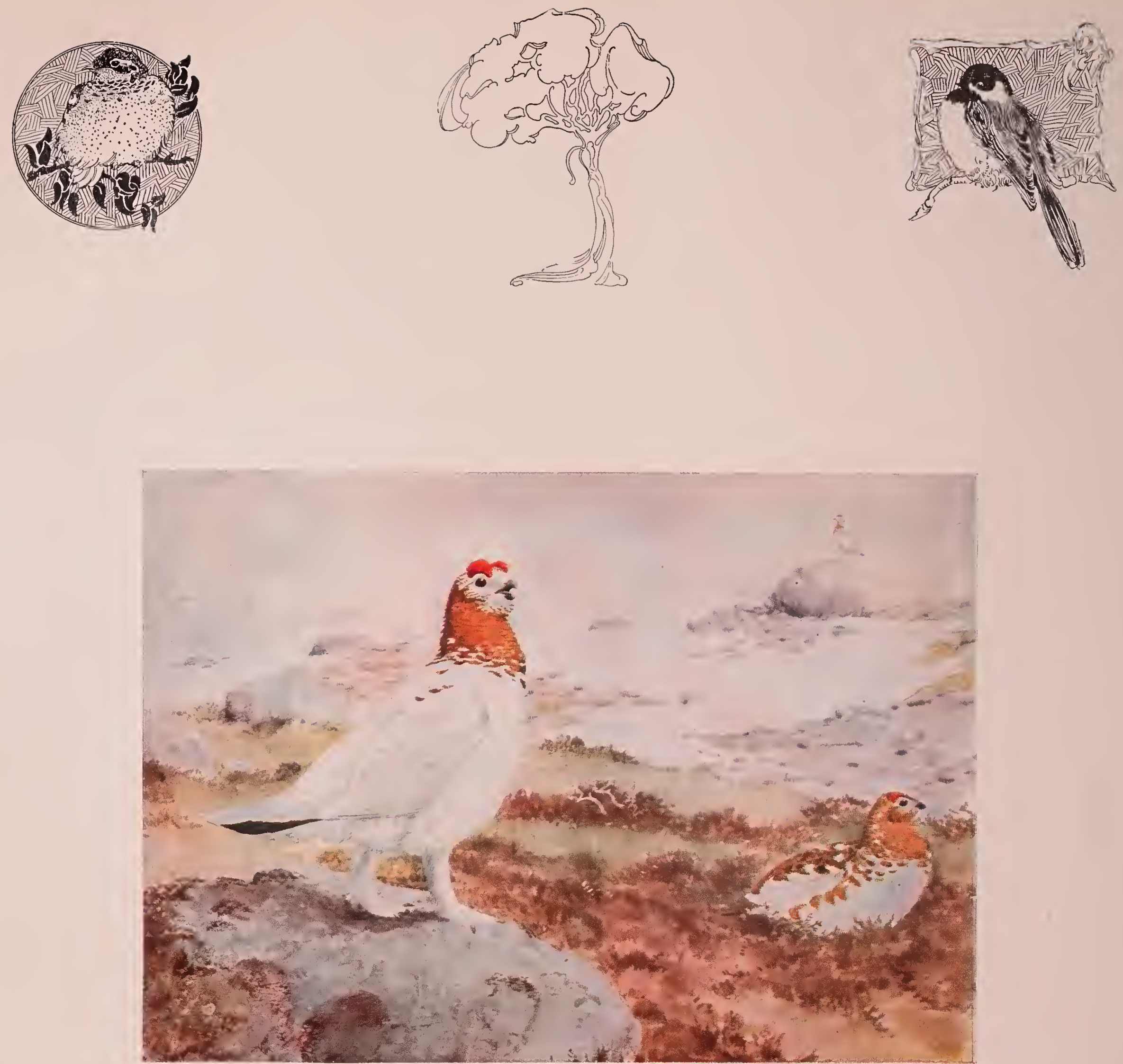

\section{YELLOW PTARMIGAN}

"The Follies foot races Made such a big hit All the birds in town Are talking about it yet.

"Such performance for birds Has never before been seen, It should now be reproduced Upon the movie screen.
"It would please all children; And most grown-ups, too, For the whole wide world It would circle all through.

"They all would be waiting, From each known place, For the show on the screen Of the 'Birds' Foot Race.'" 

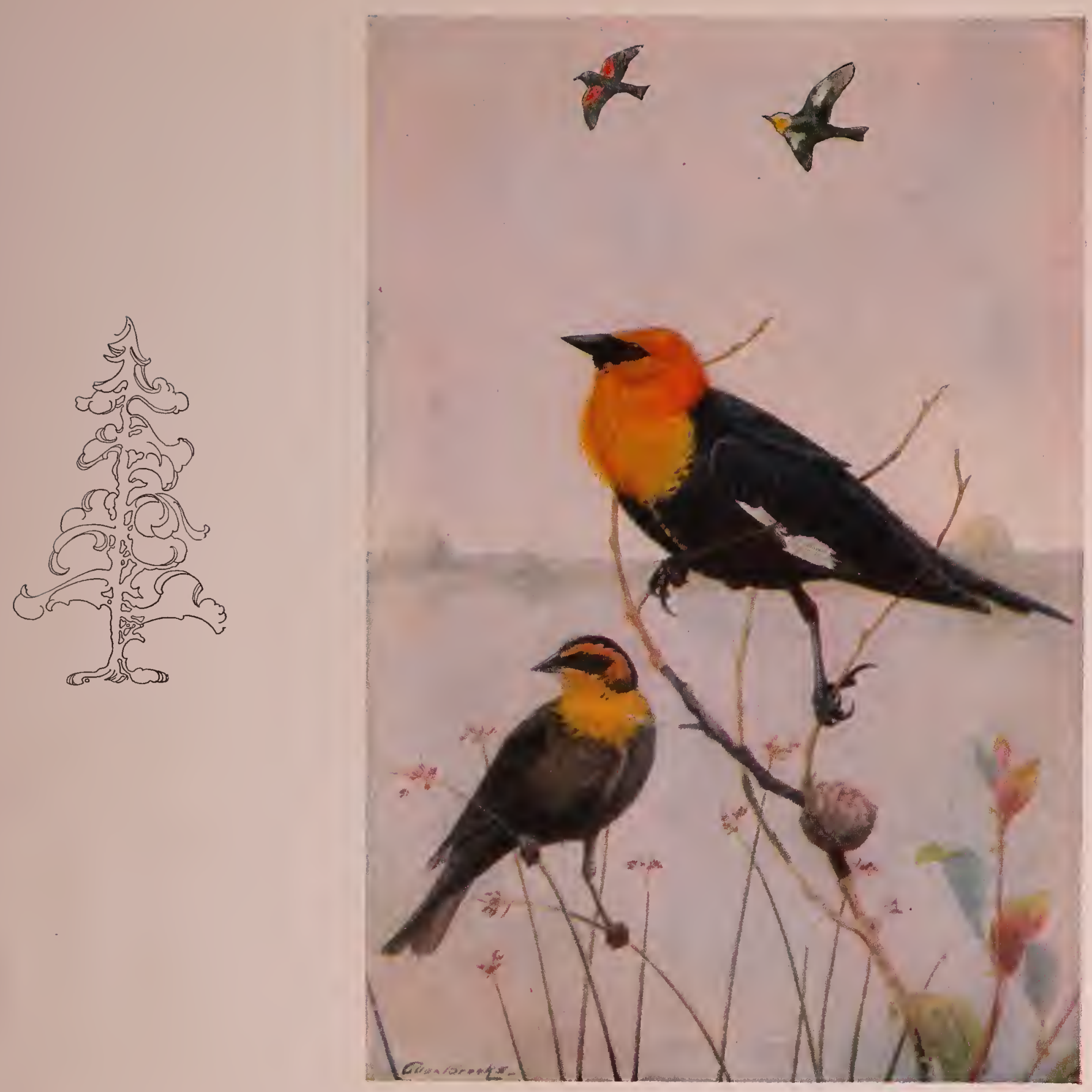

\section{YELLOW-HEADED BLACKBIRD}

"That foot race for birds,

After all's been said and done, Has proven to the nation

That birds can really run.

"It was sure good amusement

To which we all agree

That now we should arrange

To have more fun in the tree.
"The old Eagle has appointed me As a committee of one To look into the bird world And see what can be done.

"If every grove had bird houses Now wouldn't that be fine? It would give us protection At either end of the line.

"Nature's storms are so destructive

To song birds and their nests,

We all need help and protection

From the East into the West." 


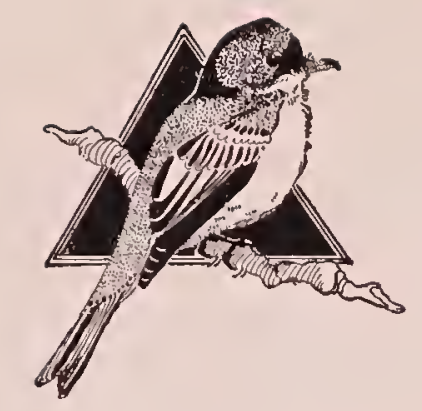

THE SANDPIPER

"That foot race in follies Made us all so much sport. Would like to have been at a distance, To receive the radio's report.

"There was so much dust In the race-track's path We came down to the beach To take a good bath.

"All the birds in the band Did their work very well Also the Bobolink and Grackles Who had charge of the hotel.

"Would like to have been in the race, Believe I could have set them a pace, But the old Eagle insisted That I help out the Police."

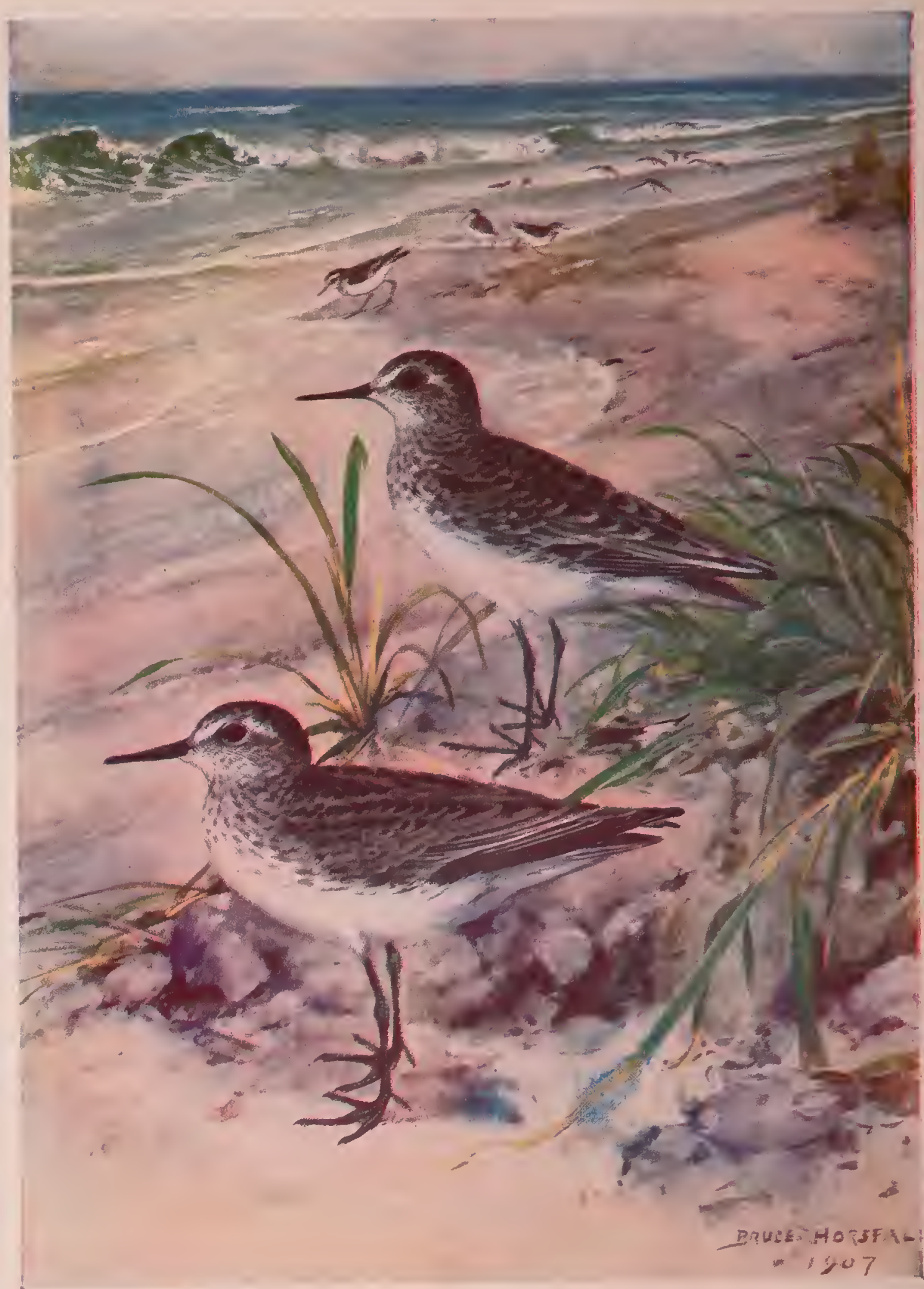

SANDPIPER

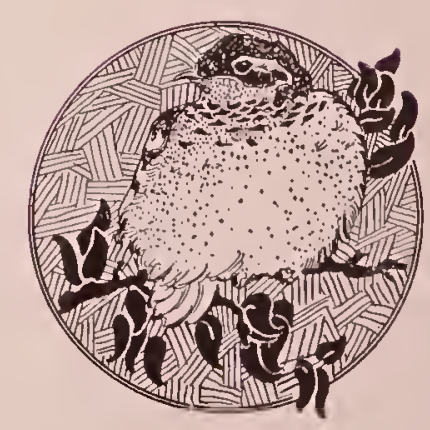



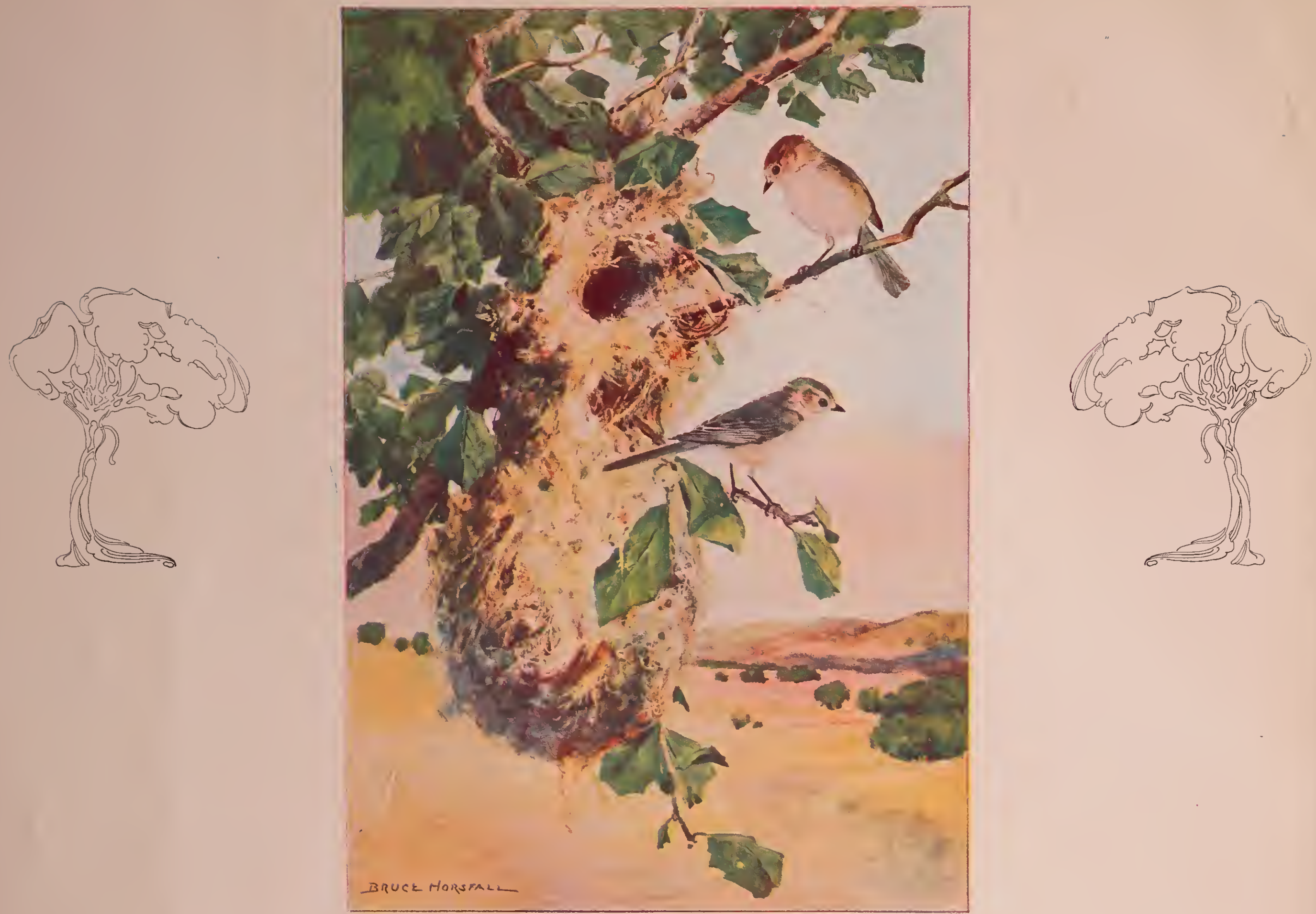

\section{BUSH-TIT}

"All the birds are so merry and cheerful And no one do they ever molest,

The happiest time in the Woodland Is when one is building its nest.

"They need lots of care and protection From the hearts of the worst and the best, So let's all join in together

And help the bird in protecting its nest.

"Good children should be the teachers For bad children and some of the rest, And when they find a little bird in trouble Play soldier and take care of its nest.

"With this combined all will be happy

The birds as well as the rest

Then you listen to the chatter at sunrise And the sweet song that comes from the nest." 





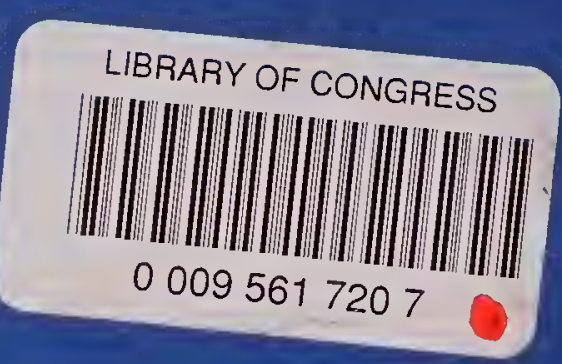

